University of Nebraska - Lincoln

DigitalCommons@University of Nebraska - Lincoln

$10-6-2021$

Diversity of Tetrabothriidae (Eucestoda) among Holarctic Alcidae (Charadriiformes): Resolution of the Tetrabothrius jagerskioeldi Cryptic Species Complex: Cestodes of Alcinae-Provides Insights on the Dynamic Nature of Tapeworm and Marine Bird Faunas under the Stockholm Paradigm

Eric P. Hoberg

University of New Mexico, geocolonizer@gmail.com

Kaylen Marie Soudachanh

University of New Mexico

Follow this and additional works at: https://digitalcommons.unl.edu/manter

Part of the Biodiversity Commons, Ornithology Commons, Parasitology Commons, and the Zoology

Commons

Hoberg, Eric P. and Soudachanh, Kaylen Marie, "Diversity of Tetrabothriidae (Eucestoda) among Holarctic Alcidae (Charadriiformes): Resolution of the Tetrabothrius jagerskioeldi Cryptic Species Complex: Cestodes of Alcinae-Provides Insights on the Dynamic Nature of Tapeworm and Marine Bird Faunas under the Stockholm Paradigm" (2021). MANTER: Journal of Parasite Biodiversity. 17.

https://digitalcommons.unl.edu/manter/17

This Article is brought to you for free and open access by the Parasitology, Harold W. Manter Laboratory of at DigitalCommons@University of Nebraska - Lincoln. It has been accepted for inclusion in MANTER: Journal of Parasite Biodiversity by an authorized administrator of DigitalCommons@University of Nebraska - Lincoln. 


\title{
Diversity of Tetrabothriidae (Eucestoda) among Holarctic Alcidae (Charadriiformes): Resolution of the Tetrabothrius jagerskioeldi Cryptic Species Complex- Cestodes of Alcinae-Provides Insights on the Dynamic Nature of Tapeworm and Marine Bird Faunas under the Stockholm Paradigm
}

\author{
Eric P. Hoberg and Kaylen Marie Soudachanh \\ Museum of South Biology, Department of Biology, University of New Mexico, Albuquerque, New Mexico, USA \\ Corresponding author - Eric P. Hoberg, Museum of Southwestern Biology, Department of Biology, University of New Mexico, \\ Albuquerque, NM 87131 USA, email geocolonizer@gmail.com,
}

ORCID: E.P. Hoberg https://orcid.org/0000-0003-0819-7437

\begin{abstract}
We begin resolution of the Tetrabothrius jagerskioeldi-species complex with descriptions of Tetrabothrius alcae n. sp. based on numerous specimens, primarily in murres (species of Uria), from the greater North Pacific basin and Tetrabothrius sinistralis n. sp. based on cestodes in guillemots (species of Cepphus) from the central Bering Sea and West Greenland. These tetrabothriids are characterized, among 44 species of Tetrabothrius in avian hosts, by attributes of the scolex, male and female organ systems, structure and dimensions of the vitelline gland, numbers of testes, configuration of the genital atrium, genital papillae and the male and female atrial canals, position of the genital ducts relative to the poral osmoregulatory canals, structure, dimensions and position of the vaginal seminal receptacle, and dimensions of the embryophore and oncosphere, in addition to a broader array of characters. Remarkably, T. alcae, T. sinistralis, and a cryptic complex had remained unrecognized for the past century, given that these species are unequivocally differentiated by multiple suites of unique structural attributes relative to $T$. jagerskioeldi. Alcids and cestodes of the T. jagerskioeldi-complex are restricted to cold marine systems of advection and upwelling along coastal margins adjacent to the continental shelf or are associated with archipelagos (especially the Aleutian Arc), isolated islands and rocky headlands of the Bering Sea, Chukchi Sea, Gulf of Alaska, Sea of Okhotsk, and Sea of Japan. Tetrabothrius alcae, T. jagerskioeldi, and T. sinistralis may occur in sympatry but with minimal overlap in the faunas associated with murres (Alcini) and guillemots (Cepphini). Transmission for cestodes and persistence of this fauna is expected to be associated with pelagic and neritic systems adjacent to colony sites in zones where critical prey species are concentrated or secondarily dispersed downstream by predictable advective and upwelling processes and become available to foraging birds. Faunal assembly represents the outcomes of oscillating climate, shifting ranges (breakdown in isolation, ecological fitting, and exploration modes for cestodes) and the changing interfaces for resource availability maintained by trophic and habitat overlaps. Dynamics at these ecotones constitute the nexus of opportunity and capacity for infection by species of Tetrabothrius among avian hosts where capacity appears broad and opportunity is ecologically restricted in space and
\end{abstract}


time. Life history pathways for cestodes are tied to trophic associations and dynamics at mesoscales across marine domains and provinces. Resilience and connectivity through ecological fitting strongly suggest the influence of multiple trophic pathways for transmission and persistence of this complex fauna through differing assemblages of zooplankters, fishes, and cephalopods depending on locality, oceanographic conditions, and temporal variability. Changing conditions, especially ecological perturbations driven by climate oscillations, directly determine production cycles and distributions of micro- and macro-zooplankton, forage fishes, cephalopods, and trophic structure in high-latitude marine ecosystems. Expanding regimes of accelerating change emphasize the critical importance of field collections, archives, and baselines to assess biological outcomes across temporal and spatial scales. Parasite assemblages reveal macro- to meso-scale connectivity serving as adjuncts and proxies in recognizing and understanding outcomes for episodes of environmental oscillation and directional atmospheric and oceanic warming in marine ecosystems.

Keywords: Tetrabothrius alcae n. sp., Tetrabothrius sinistralis n. sp., Alcidae, marine diversity, faunal assembly, climate, Stockholm paradigm dynamics

\section{Introduction}

Large robust cestodes attributable to species of Tetrabothrius Rudolphi, 1819 appear as characteristic parasites among charadriiform seabirds of the family Alcidae across high-latitude seas of the Holarctic (Hoberg and Soudachanh, 2020). A single oceanographically widespread species, Tetrabothrius jagerskioeldi Nybelin, 1916, had generally been regarded to have a considerable host range among alcids (e.g., Baer, 1954; Temirova and Skrjabin, 1978; Muzzafar and Jones, 2004). In contrast, Hoberg and Soudachanh (2020), in a synthesis of 40 years of geographically extensive field inventories, demonstrated that a species complex, minimally including 3 unrecognized and undescribed taxa, has been hidden within T. jagerskioeldi for the past century.

In our evaluations of diversity, specimens of $T$. jagerskioeldi, in addition to the original type series (including T. intrepidus Baylis, 1919) from Sweden and the Barents Sea (Nybelin, 1916; Baylis, 1919), were identified primarily among guillemots (Cepphini), species of Cepphus Pallas [pigeon guillemot, C. columba Pallas, 1811; spectacled guillemot, C. carbo Pallas, 1811; and black guillemot, $C$. grylle (Linnaeus, 1758); prevalence of $37 \%, 50 \%$, and $12.5 \%$, respectively] occurring at 6 insular localities spanning the North Pacific basin across the northern Sea of Okhotsk, Bering Sea, and Gulf of Alaska (Hoberg and Soudachanh, 2020). We confirmed the identity of T. jagerskioeldi and a patchy distribution for this tetrabothriid among alcid (6 species), larid (glaucous-winged gull, Larus glaucescens Naumann, 1840), and phalacrocoracid [pelagic shag, Urile pelagicus (Pallas, 1811)] hosts based on these collections and direct comparisons to the type series of Nybelin
(1916). Alcids, other than guillemots, were rarely observed as hosts, and cestodes occurred in single specimens of common murre [Uria aalge (Pontoppidan, 1763)], marbled murrelet [Brachyramphus marmoratus (Gmelin, 1789)], and rhinoceros auklet [Cerorhinca monocerata (Pallas, 1811)]. Specimens of $T$. jagerskioeldi were not collected nor identified in other species of auks (Alcini), puffins (Fraterculini), auklets (Aethiini), or murrelets (Brachyramphini and Synthliboramphini) from the North Pacific basin (Hoberg and Soudachanh, 2020). Following the original description of T. jagerskioeldi, a broad oceanographic range across seas of the Holarctic has been established for this tetrabothriid.

Tetrabothrius jagerskioeldi, consistent with a conventional understanding of marine parasite diversity and the otherwise traditional model for cospeciation (see for discussion Nylin et al., 2018; Brooks et al., 2019), would have been predicted as a common helminth among murres, species of Uria Brisson, 1760 (e.g., Muzzafar and Jones, 2004). In our ongoing studies, however, authoritative identification of T. jagerskioeldi revealed this cestode species in 1 of 276 specimens of common murres $(<1 \%)$ and none among 150 specimens of thick-billed murres, U. lomvia (Linnaeus, 1758), across localities from the greater North Pacific basin (Hoberg and Soudachanh, 2020). Because of the recognition of a putative species complex and a nearly uniform absence of archived specimens on which to establish identity in global museum collections, prior records of T. jagerskioeldi in murres, especially from the Arctic Basin and North Atlantic (e.g., Belopol'skaia, 1952; Threlfall, 1971), and other species of alcids are equivocal and can now rarely be substantiated (Hoberg and Soudachanh 2020).

In our current study, we have updated and revised our records for host and geographic occurrence and preva- 
lence for species of the $T$. jagerskioeldi-complex arising from the original inventories between 1950 and 1992 across the North Pacific (Hoberg and Soudachanh, 2020). Data encompassing additional specimens of seabirds collected after 1992 from the Bering Sea and Aleutian Islands are summarized. These latter observations broaden the baseline originally reported by Hoberg and Soudachanh (2020) to include 1,871 seabirds of 34 species across 55 localities, and 1,345 Alcidae of 18 species (Supplementary Data Tables 1-3). Cestodes of the complex are now documented, based on inventory, in 102 of 1,871 seabirds examined (5\%) and among 1,345 alcids ( $8 \%$ ) of 12 species (Supplementary Data Table 3). An additional occurrence for a previously undescribed Tetrabothrius has been linked to specimens originally attributed to T. jagerskioeldi collected by J. G. Baer during July 1955 in 1 of 3 black guillemots adjacent to Kangerluk (formerly Diskofjord), West Greenland (ca. $69^{\circ} 29^{\prime} \mathrm{N}, 53^{\circ} 56^{\prime} \mathrm{W}$ ) (Baer, 1956); further, 2 specimens of C. grylle examined on 20 August 1955 from Kronprinsens Ejland, Qaasuitsup, West Greenland (ca. 69 $01^{\circ} \mathrm{N}, 53^{\circ} 19^{\prime} \mathrm{W}$ ) were not infected. We also note a corrected record for specimens of an unknown species of Tetrabothrius in Scripp's murrelets [Synthliboramphus scrippsi (Green and Arnold, 1939)] which had been erroneously referred to the complex by Hoberg and Soudachanh (2020) (Supplementary Data Tables 3 and 4).

Overall, 13 of 20 avian species that have been examined among the 24 extant members of the Alcidae [25 species with inclusion of the extinct great auk, Pinguinus impennis (Linnaeus, 1758)] across Holarctic seas were identified as hosts for cestodes of the T. jagerskioeldicomplex (Hoberg and Soudachanh, 2020). These cestodes, other than T. jagerskioeldi, were not observed in avian taxa beyond the Alcidae, including sympatric species of Stercorariidae, Laridae, and Phalacrocoracidae. Species of the complex appear to have limited host ranges among the Alcidae and, further, have not been collected or observed among an assemblage of Procellariiform seabirds in sympatry across the North Pacific Ocean and Bering Sea ecosystem during the boreal summer (E.P. Hoberg, unpublished data).

The general absence of archived specimens in alcids from most localities in the greater North Atlantic basin and from Russian and Japanese localities in the northwestern Pacific currently precludes a synoptic understanding of the broader host and geographic distribution of tetrabothriid cestodes, including those of the T. jagerskioeldicomplex (Hoberg and Soudachanh, 2020). Specimens of robust tetrabothriids in murres appear historically to have been largely misattributed to T. jagerskioeldi (see Temirova and Skrjabin, 1978; Muzzafar and Jones, 2004). Among these, an undescribed species of Tetrabothrius, as a component of the T. jagerskioeldi-complex, occurred in 53 of 1,345 avian specimens (4\%), composing 5 of 18 species of Alcidae examined [predominantly in common murre and thick-billed murre; infrequently in pigeon guillemot, ancient murrelet [Synthliboramphus antiquus (Gmelin, 1789)], and parakeet auklet [Aethia psittacula (Pallas, 1769)] from 11 of 55 localities across the greater North Pacific basin, representing marine inventory between 1950 and 2002 (Supplementary Data Tables 1-3). A broad oceanographic distribution is documented, encompassing the region from Humboldt Bay, California, in the eastern North Pacific through the Gulf of Alaska, Bering Sea, Chukchi Sea, and Aleutian Islands to the northern Sea of Okhotsk in the west. Cestode specimens necessary to examine potential distributions in the Arctic basin and adjacent North Atlantic are not available.

It is also now evident that multiple species of large Tetrabothrius, including $T$. jagerskioeldi, occur in guillemots (Hoberg and Soudachanh, 2020) (Supplementary Data Table 3). Among these, an apparently rare cestode, a second distinct species in the complex, is represented by 3 fully developed specimens collected at single localities from the central Bering Sea (in pigeon guillemot at St. Matthew Island, Alaska; overall, 1 of 1,345 alcids, $<1.0 \% ; 1$ of 22 C. columba but not in C. carbo or C. grylle from the North Pacific basin) and from West Greenland as noted previously (in black guillemot). The latter specimens held in the Museum d'Histoire Naturelle (MHN), Geneva had originally been identified as T. jagerskioeldi by Baer (1956).

In our expanding exploration of diversity, 2 previously unrecognized species of Tetrabothrius, primarily among murres and guillemots (Alcinae), are characterized through comparative morphological approaches; 2 additional undescribed species primarily among the Fraterculinae will be designated in a subsequent study. Specimens or tissues suitable for molecular systematics and integrated analyses are not available. Cestode specimens, respectively, from the MHN and an assemblage of alcid hosts now archived in the Parasitology Division, Museum of Southwestern Biology, University of New Mexico (MSB), contribute to our present observations and descriptions. Taxonomic resolution provides an opportunity to explore the historical, ecological, and biogeographical parameters for assembly of the tetrabothriid fauna among North Pacific seabirds, along with consequences for restructuring of nektonic communities under climate oscillation and anthropogenic warming in high-latitude oceans. 


\section{Methods and Materials}

\section{Specimens Examined}

We update and incorporate new field data (Supplementary Data Tables 2 and 3) from 1992 to 2002 into summaries previously outlined in Hoberg and Soudachanah (2020). Cestode specimens examined in the course of a comprehensive redescription of T. jagerskioeldi, as a basis for establishing morphological and taxonomic limits within the species complex, were outlined by Hoberg and Soudachanh (2020). Specimens now designated in the type and voucher series for 2 previously unrecognized species within the complex, described in our current study, are archived in the Parasitology Division, Museum of Southwestern Biology, University of New Mexico, Albuquerque (Supplementary Data Table 4). Primary data for field collections, including host occurrence and georeferenced localities (Supplementary Data Tables 2 and 3), are held in the Arctos data platform (http://arctos. database.museum). Host taxonomic nomenclature follows Chesser et al. (2020) for species of Alcidae, Laridae, Stercorariidae, and genera and species of Procellariiformes and Kennedy and Spencer (2014) for Phalacrocoracidae (shags and cormorants).

Cestode specimens from inventory collections of seabirds between 1975 and 2002 were usually fixed in buffered $10 \%$ formalin or $70 \%$ ethanol; specimens collected by other field biologists prior to 1975 were fixed in $10 \%$ formalin. Prior to fixation, cestodes immediately recovered from avian specimens during field collections were allowed to relax for an extended period of time in water at ambient temperature. Cestodes were heat-killed in either $\mathrm{H}_{2} \mathrm{O}$ or in fixative. Strobilate specimens were generally prepared as whole mounts stained in Semichon's acetic carmine, destained in $70 \%$ ethanol and $\mathrm{HCl}$, dehydrated through a series of ethanol, cleared in terpineol or xylene, and mounted in Permount or Canada balsam. Tegument was stripped from the strobila of some series of specimens at the time of clearing to facilitate examination of internal anatomy in whole mounts. Handcut thick sections were generally prepared from each strobila coincidental with clearing. Transverse sections were prepared in reference to ontogeny of the male and female reproductive systems to view the progressive development of the genital atrium, male and female genital ducts and uterus, and to confirm the position of the genital ducts and transverse uterus relative to the poral osmoregulatory canals. Designation of immature, mature, postmature, pregravid, and gravid proglottids follow definitions proposed in prior taxonomic studies of tetrabothriids (Murav'eva and Popov, 1976; Hoberg, 1987b; Hoberg et al., 1991) and provide the basis for direct comparisons of genital organ systems at comparable stages of ontogeny (Rawson, 1964). Identifications for this series of specimens were limited to comparative morphological approaches. Molecular phylogenetic analyses were not possible for specimens because of their age and time frames for field collections in the 1950s to 2002, and a long history of storage at ambient temperatures in $10 \%$ formalin, varying grades of ethanol, and other reagents.

\section{Results}

\section{Expanding Diversity in the T. jagerskioeldi-Com- plex, Cestodes in Murres}

A previously unrecognized species of Tetrabothrius, a component of the T. jagerskioeldi-complex, occurred in 5 species of Alcidae among 18 examined and from 11 of 55 localities across the greater North Pacific basin (encompassing the region from Humboldt Bay, California, in the east through the Bering Sea, Chukchi Sea, and Aleutian Islands to the northern Sea of Okhotsk, Russia, in the west) representing inventory between 1950 and 2002 (Supplementary Data Table 3).

Cestodes we attribute to Tetrabothrius alcae n. sp. were found as parasites in 53 hosts among 1,345 (4\%) alcids examined. These cestodes were predominantly observed in species of murres and among 49 of 426 of these seabirds, irrespective of age or breeding status (prevalence 11.5\%), as summarized in Supplementary Data Table 3. Among common murres, T. alcae occurred in 32 of $276(12 \%$; intensity $=1-19$ cestodes per host) across 6 of 17 localities where this avian species was collected. Among thick-billed murres, cestodes were found in 17 of 150 examined (11\%; intensity $=1-16$ ) across 7 of 14 sites. Tetrabothrius alcae occurred sporadically in other species of alcids. We discovered T. alcae in a pigeon guillemot (1 of 22, 4.5\%; single gravid specimen at St. Lawrence Island) but not in C. carbo (4 examined) or C. grylle (8); in ancient murrelets (2 of 51, $4 \%$; with single gravid cestode specimens, respectively, at St. Lawrence Island and from pelagic waters south of the western Aleutian Islands) but not in S. scrippsi (4); and in a parakeet auklet (1 of 56, 2\%, 3 postlarval specimens from Talan Island). Specimens attributable to T. alcae (or T. jagerskioeldi) were generally not found among Fraterculinae, including other species of auklets (Aethiini), Aethia Merrem, 1788, and Ptychoramphus Brandt, 1837, nor among puffins (Fraterculini) of the genera Cerorhinca Bonaparte, 1828 and Fratercula Brisson, 1760 (Supplementary Data Table 3). Specimens of T. alcae were observed in multiple host species in sympatry (but not consistently synchronic) from pelagic waters south of the Aleutian Islands (U. lomvia, 
S. antiquus), St. Lawrence Island (U. Lomvia, C. columba, S. antiquus), St. Matthew Island (U. aalge, U. lomvia), and Talan Island (U. aalge, U. lomvia, A. psittacula).

Among all species of murres, relative to breeding status and age of hosts, specimens of $T$. alcae were discovered in 24 of 356 breeding adult birds (7\%), 13 of 37 nonbreeding subadults (35\%), and 12 of 33 chicks at fledging (36\%). Among common murres across all localities, T. alcae occurred in 11 of 216 breeding adult birds (5\%), 10 of 29 subadults (34\%), and 11 of 31 chicks at the time of fledging (35\%). Among thick-billed murres, cestodes were found in 13 of 140 adults (9\%), 3 of 8 subadults (37\%), and 1 of 2 fledglings.

Primary materials representing $T$. alcae include specimens in 40 alcid hosts (24 U. aalge, $12 \mathrm{U}$. lomvia, $2 \mathrm{~S}$. antiquus, and single C. columba and A. psittacula), with 47 cestodes on 91 slides in the type series on which the description is based (Supplementary Data Table 4); specimens in one ancient murrelet and a parakeet auklet are excluded from the type series and are included as vouchers. Additionally, there are 67 stained and mounted vouchers, primarily postlarval or immature specimens, on 37 slides, identified based on the characteristic configuration and structure of the scolex. Additional unmounted specimens from the type and voucher series are held in vials in $70 \%$ or greater ethanol.

\section{Description-Tetrabothrius alcae n. sp.}

Figures $1-29$

General Description: (Based on complete and partial observations and measurements from 47 specimens in the type series.) Large, robust, tetrabothriids; maximum length of strobila $127-210 \mathrm{~mm}$, with $529-700$ proglottids in gravid specimens. Segments wider than long throughout strobila; 94-182 long $\times 1,636-2,457$ wide in immature proglottids; 195-455 × 3,003-5,005 in mature; 455-1,105 × 4,355-6,166 in gravid. Length:width ratio 1:9.29-17.98 in immature; 1:9.63-15.68 in mature; $1: 4.86-13.43$ in gravid. Scolex rectangular, consistently wider than long $(n=40) 190-392$ (297) long $\times$ 201-422 (359) wide; auricles not prominent. Bothridia suckerlike, deep, well developed, $(n=146) 152-255$ (212) long $\times$ 103-198 (168) wide, with muscular margins. Apical region hypertrophied, domelike, expanded anterior to auricles. Neck, as measured from base of scolex to first indication of internal segmentation, relatively long, $(n=$ 32) $500-1,550$ (843) in length $\times 274-577$ (428) wide, often appearing inflated. Ventral osmoregulatory canals 41-169 in diameter; transverse canal $16-74$, often with multiple anastomoses; dorsal canals $17-41$ in diameter. Dorsal canal shifted mediad relative to ventral canal. Occasionally 3 dorsal canals present, with one pair situated in poral $1 / 3$ of segment. Anastomoses of osmoregulatory system visible in scolex, extending into neck. Genital pores unilateral, dextral in dorsal orientation of strobila, situated marginally in middle third of proglottid. Male and female genital ducts and extensions of transverse uterus pass ventrally to poral osmoregulatory canals.

Longitudinal Musculature: Musculature prominent in transverse sections of proglottids; inner and outer bundles arranged in single layers. Inner bundles large in diameter; $(n=22)$ 95-177 (139) in number; $(n=55)$ 9-72 (35) fibers per bundle. Outer bundles relatively small in diameter; $(\mathrm{n}=$ 10) 183-235 (217) in number; $(n=100) 2-15$ (7) fibers per bundle. Numbers of muscle bundles maximum in mature proglottids, diminishing in number posteriad in postmature and gravid segments.

Male Genitalia: Genital anlagen visible immediately posterior to neck, protandrous; first testes observed in 130th160 th segment; mature in 250 th-300th segment. Testes positioned dorsally in 1-2 layers surrounding and partially overlapping female organs, with gap along anterior margin of vitelline gland and ovary; $(n=130) 52-105(74)$ in diameter. Testes ( $n=230$ segments from 17 strobila) 75134 (100) in number in immature segments, decreasing posteriad to ( $n=110$ segments from 10 strobila) 66-111 (87) in number with maturation of male and female organs; overall ( $n=340$ segments) 66-134 (96). Vas deferens prominent, highly convoluted, distended adjacent to poral osmoregulatory canals. Cirrus sac ovoid, situated in dorsal aspect of genital atrium, $(n=500)$ 80-137 (107) increasing in diameter posteriad in strobila, attaining maximum dimensions in late maturity; muscular wall thickened, $(n=$ 50) 5-10 (8). Cirrus sac contains extension of convoluted vas deferens and cirrus armed with miniscule but prominent spines. Genital atrium ovoid, highly muscularized ( $\mathrm{n}$ = 400) 140-304 (218) attaining maximum diameter in late maturity. Male genital canal, as viewed in transverse sections, dorsal, extending through wall of atrium, with slight ventral curve, opening through prominent, weakly bilobed papilla in center of atrial lumen; sphincters not observed. Length of male genital canal increases with age of proglottid and development of genital atrium; $(n=29) 44-68$ (55) long in early maturity; $(n=94) 65-94(77)$ in late mature to pregravid segments; overall $(n=123) 44-94$ (72) in length. 
Figures 1-2. Tetrabothrius alcae n. sp. Fig. 1. Scolex in dorso-ventral view from paratype specimen (2640-3A); note structure of weakly developed, laterally directed auricles near anterior margins of deep, strongly developed, suckerlike bothridia and domelike apical region. Fig. 2. Scolex in lateral view from paratype specimen (2640-4A); note disposition of inconspicuous auricles.

Figures 3-4. Tetrabothrius alcae $\mathrm{n}$. sp., showing structure of proglottids and configuration of male and female organ systems. Fig. 3. Proglottid in early maturity in dorsal view, whole mount from holotype (2640-1A); note dextral genital pore, ventral genital ducts and nascent uterus, distribution of testes, and elongate vitelline gland on anterior margin of lobate, biwinged ovary. Fig. 4. Proglottid in maturity, dorsal view, whole mount from holotype (2640-1A), showing region from near midline to genital pore margin; note ventral position of genital ducts and uterine stem relative to poral osmoregulatory canals, elongate and cylindrical to pyriform vaginal seminal receptacle, voluminous and convoluted vas deferens, and prominent subspherical genital atrium and cirrus sac.

Figures 5-7. Tetrabothrius alcae n. sp., showing configuration of the genital atrium and relative positions of the cirrus sac, terminal vagina, and male and female atrial canals. Fig. 5. Genital atrium in early maturity, dorsal view, whole mount, from holotype (2640$1 \mathrm{~A})$; note position of cirrus sac with convoluted vas deferens and cirrus, ventral vagina, and weakly bilobed genital papilla in dorsal aspect of atrium, and developing uterine stem. Fig. 6. Genital atrium in maturity, dorsal view, whole mount, from holotype (2640$1 \mathrm{~A})$; note ventral positions of the vagina, vas deferens, and uterine stem relative to poral osmoregulatory canals, structure of bilobed genital papilla, and apertures of the male and female genital canals. Fig. 7. Genital atrium in pregravid condition, dorsal view, whole mount, from holotype (2640-1A); note bilobed genital papilla, subspherical cirrus sac, and male canal positioned dorsally to terminal vagina with expansion of atrial seminal receptacle.

Figures 8-9. Tetrabothrius alcae n. sp., showing configuration of the genital atrium and relative positions of the cirrus sac, terminal vagina, and male and female genital atrial canals from hand-cut transverse sections. Fig. 8. Genital atrium in early maturity, dorsal to top, from holotype specimen (2640-1B); note relative position of the cirrus sac, weakly curved male atrial canal, terminal vagina and thick-walled female canal, entering muscular atrium at $90^{\circ}$ to male system. Fig. 9. Genital atrium and poral margin of proglottid in post maturity, dorsal to top, from holotype specimen (2640-1C); note positions and structure of the outer and inner bundles of longitudinal musculature, ventral position of the genital ducts relative to the dorsal and ventral osmoregulatory canals, strongly muscular genital atrium, weakly curved male canal, terminal vagina turning $90^{\circ}$ at entry to atrial wall, and expansion of atrial seminal receptacle.

Figures 10-11. Tetrabothrius alcae n. sp., showing details of female organ systems and egg. Fig. 10. Female genital ducts in early maturity, ventral view from paratype (018-75 A-2), showing the configuration of the vagina, internal seminal receptacle, ovarian duct, common vitelline duct, ascending uterine stem, and transverse uterine stem relative to the ovary and vitelline gland. Fig 11. Egg, showing structure from holotype specimen (2640-1G), with granular capsule, ellipsoidal hyaline embryophore, oncosphere, and oncospheral hooks. 
1
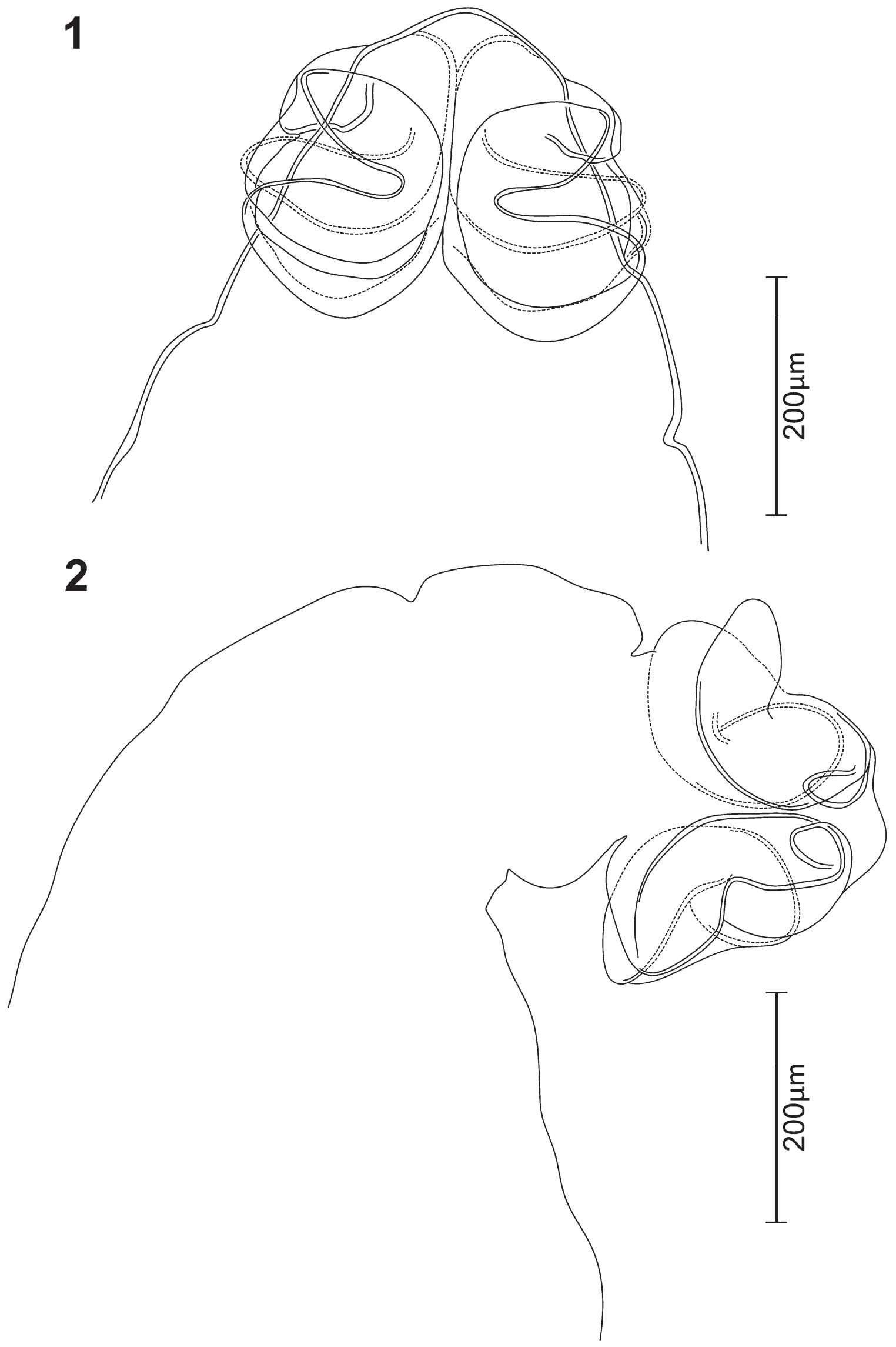

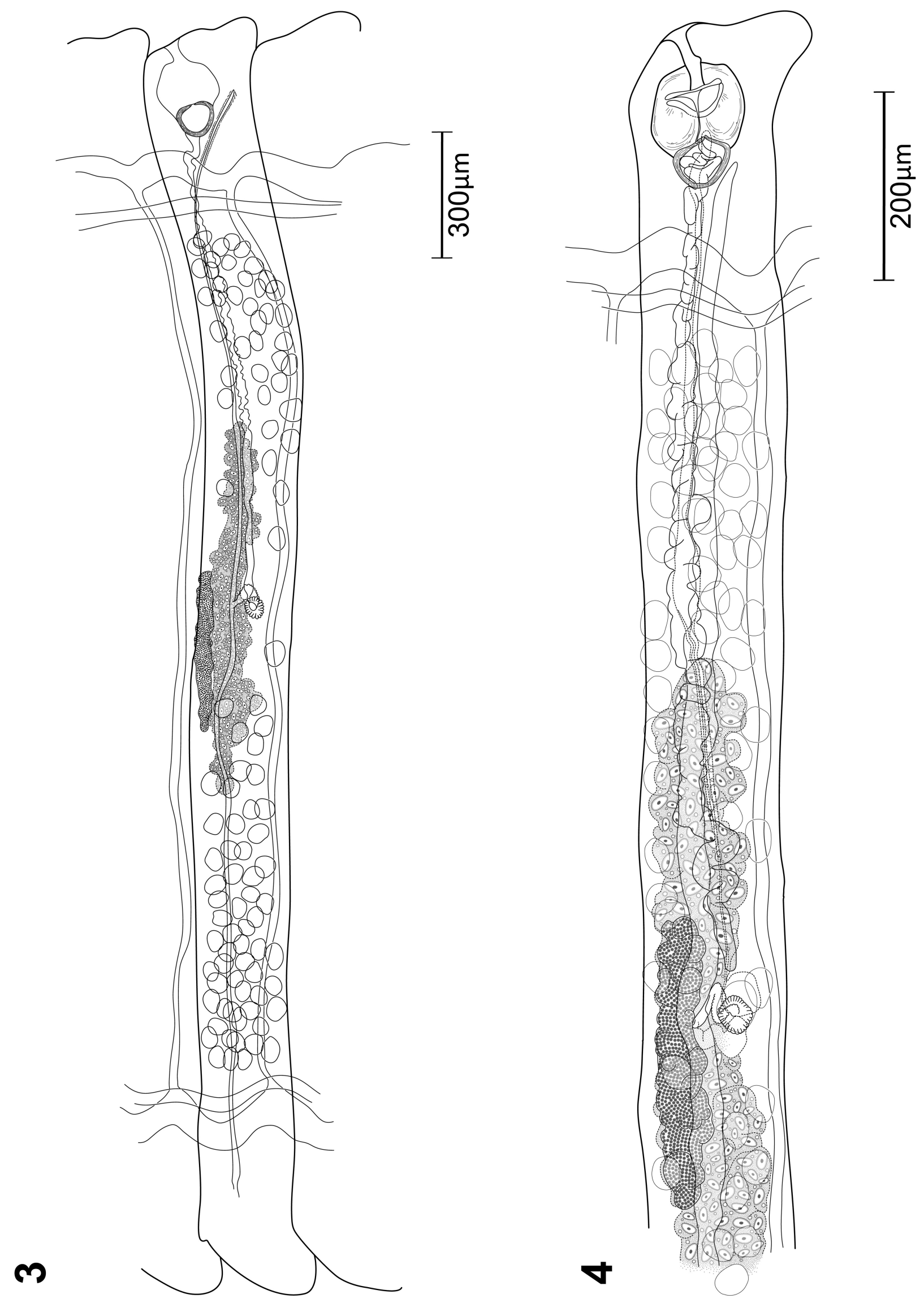

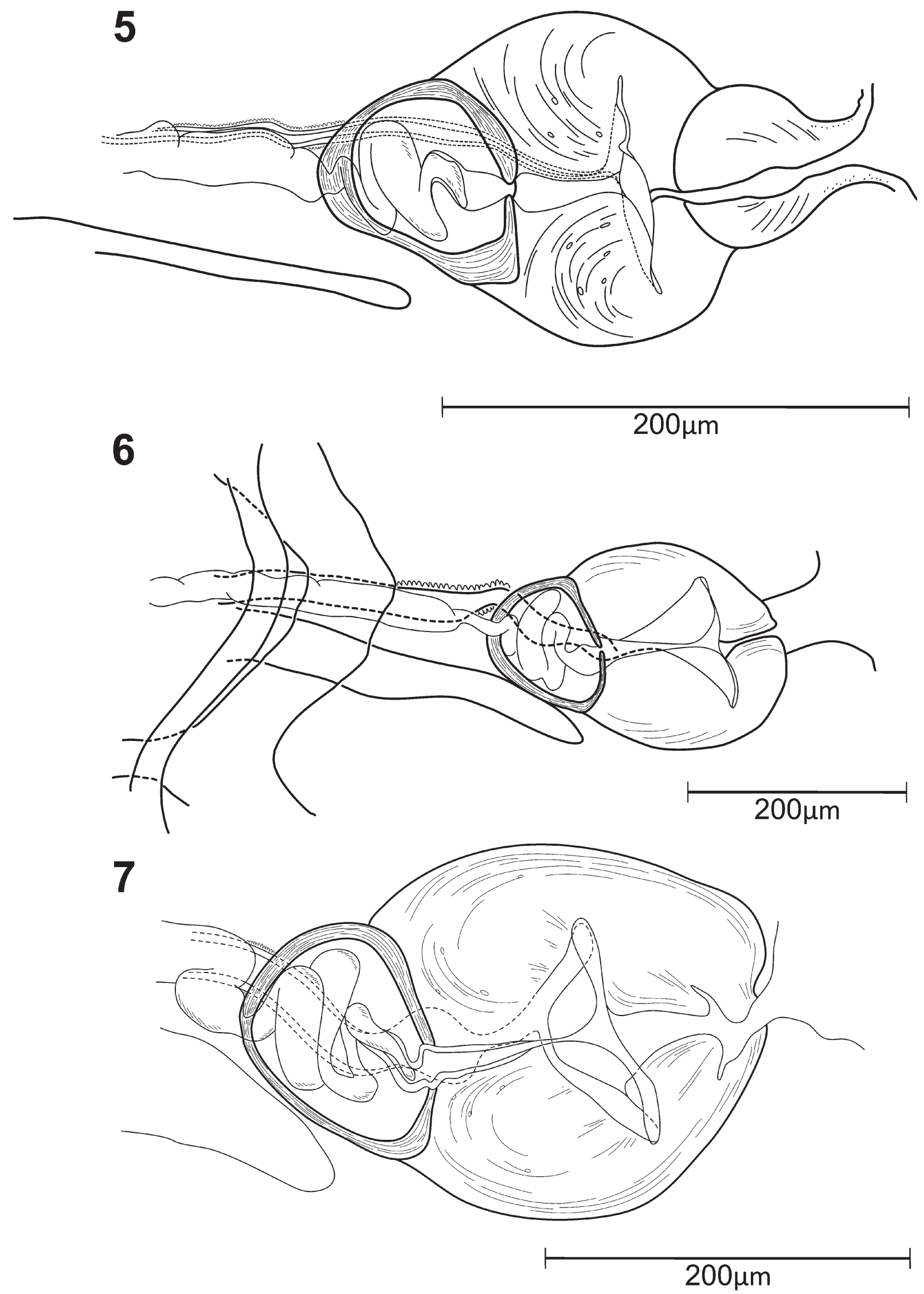
8

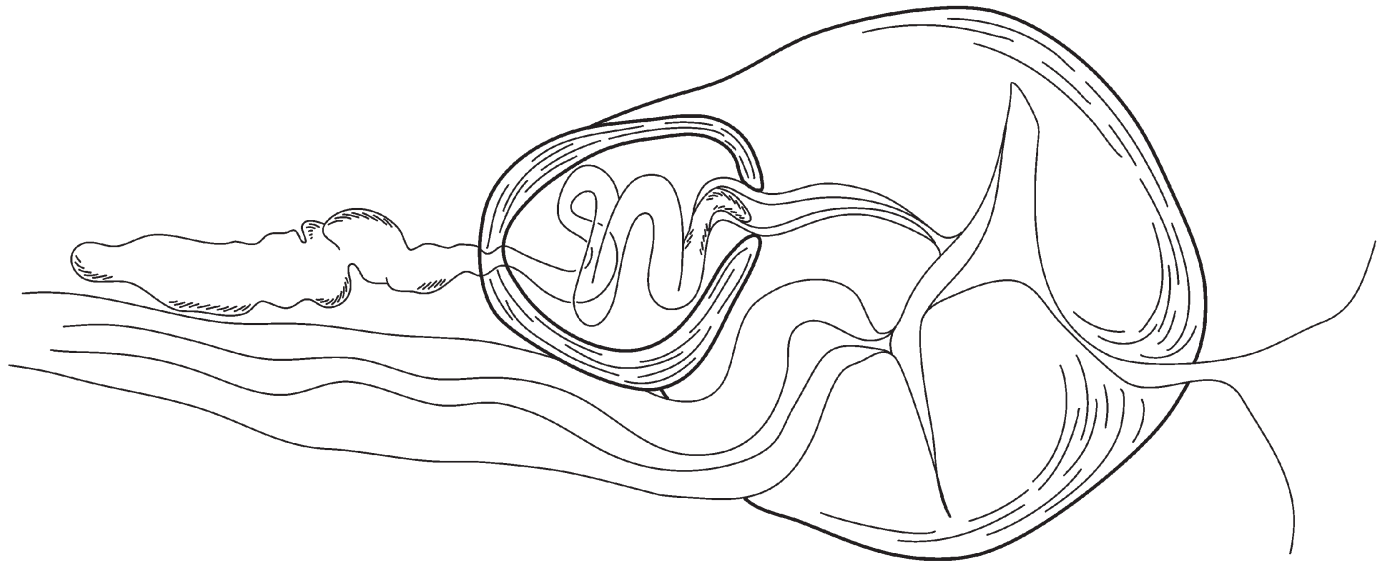

$9200 \mu m$ 0.00000 .0 -

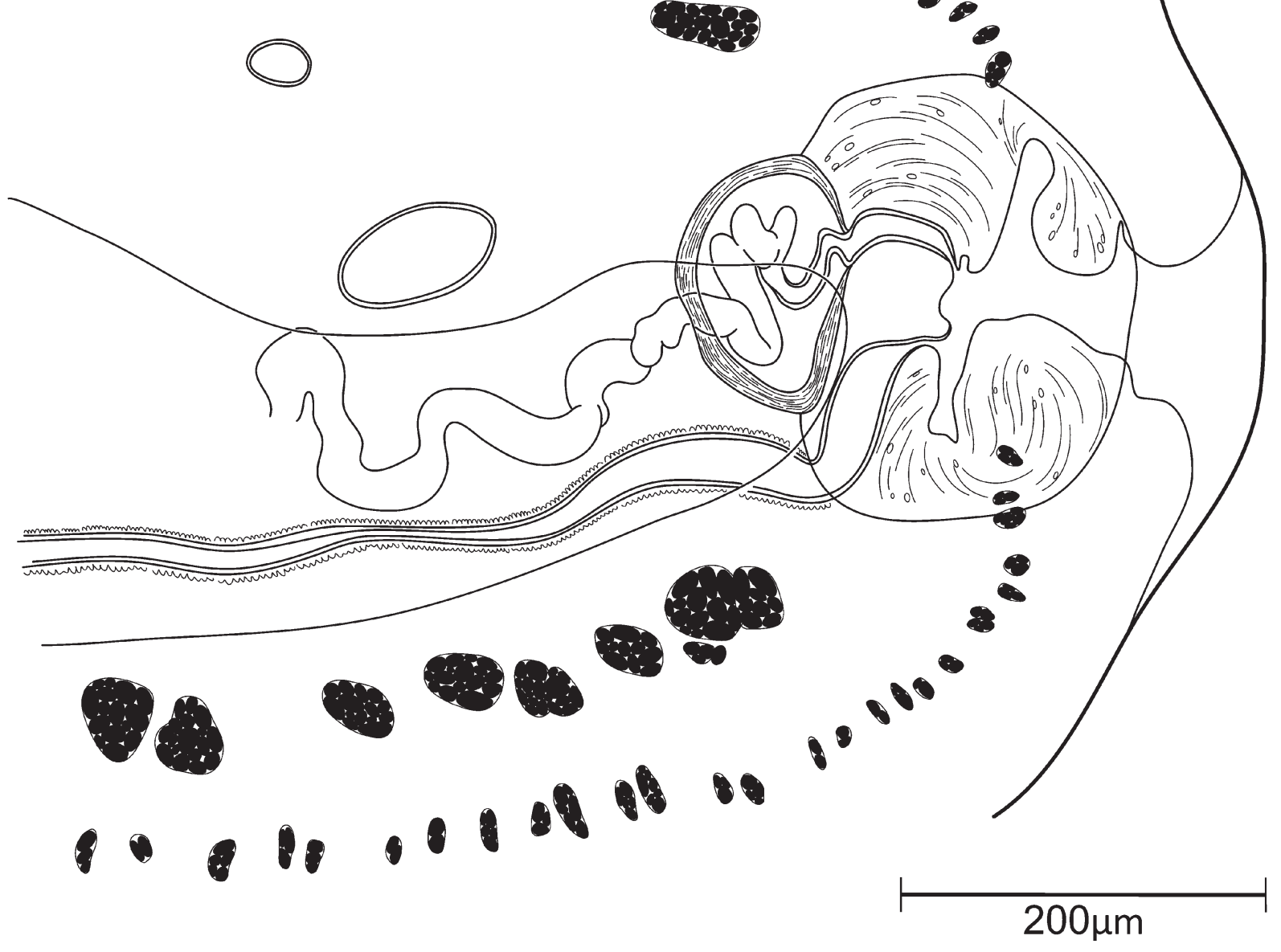




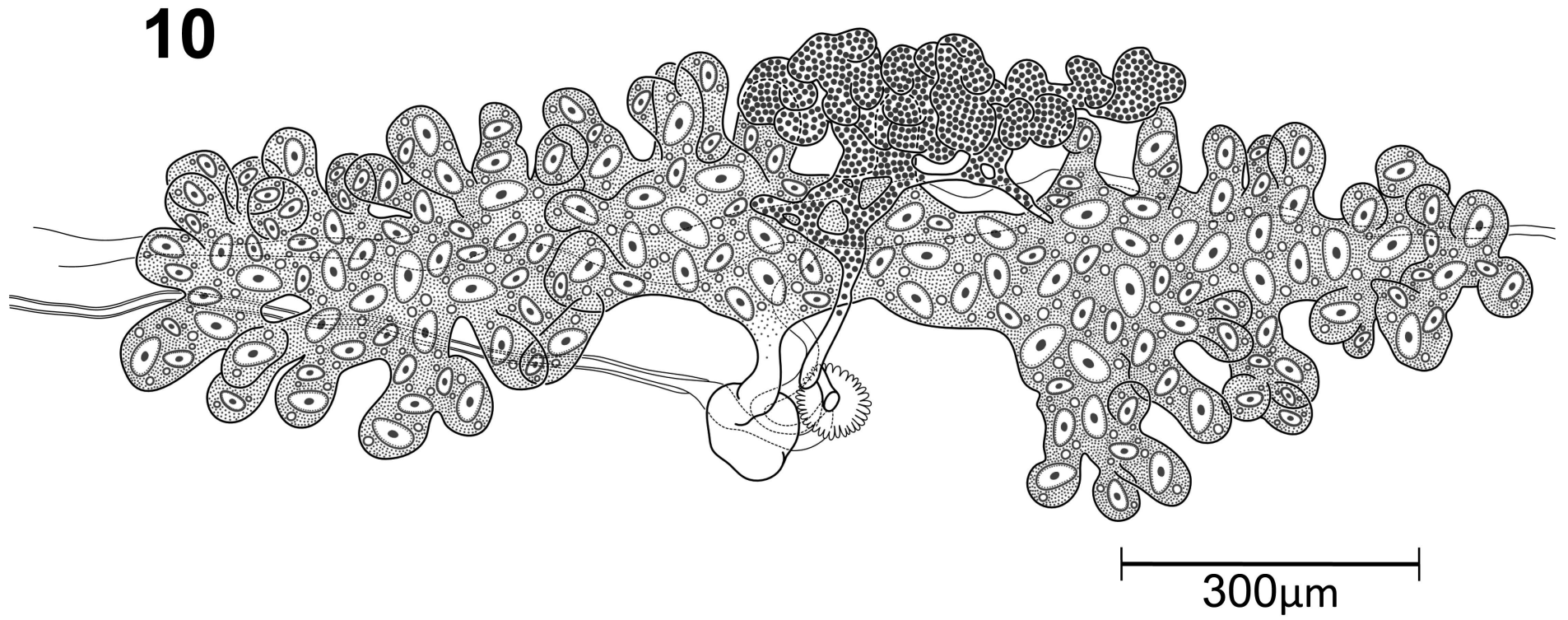

11

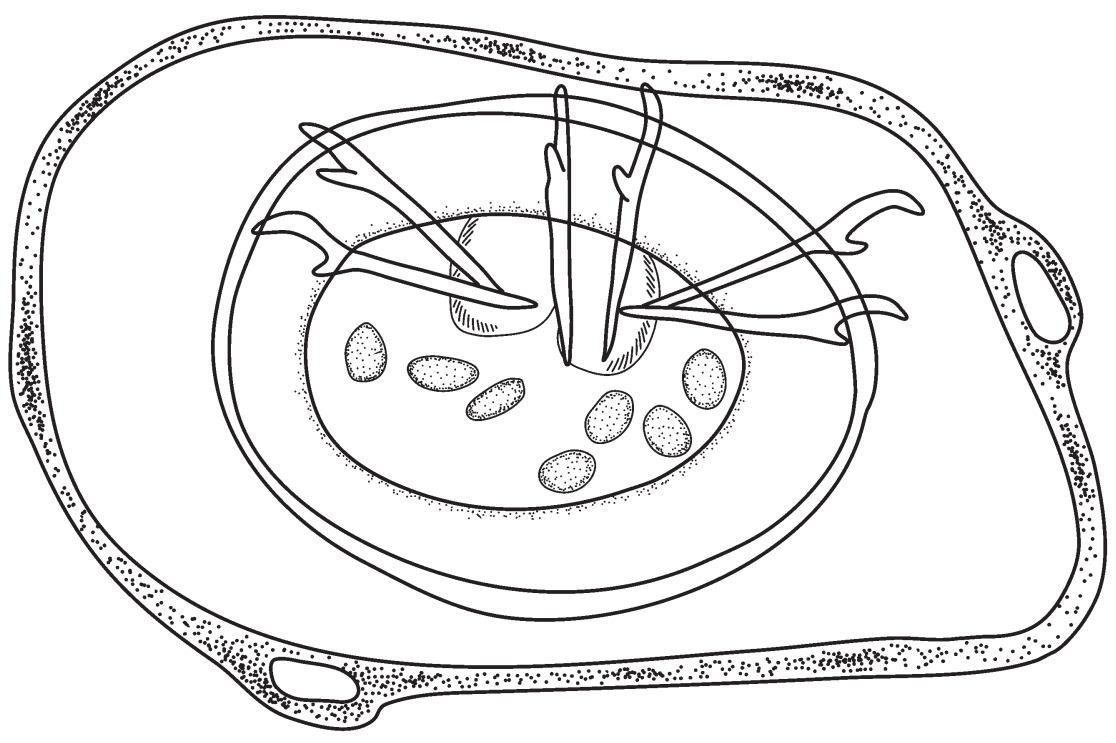

$50 \mu \mathrm{m}$ 
Figures 12-15. Tetrabothrius alcae n. sp., showing structure of scolex and bothridia from micrographs of whole-mounted strobilate, gravid specimens (scale bars in micrometers). Fig. 12. Scolex and elongate neck region in paratype specimen (2640-3A), dorsoventral view. Fig. 13. Scolex detail showing strongly developed suckerlike bothridia and reduced auricles; note the prominent domelike apical region. Fig. 14. Scolex and elongate neck region in paratype specimen (018-75-A), showing lateral view of suckerlike bothridia. Fig. 15. Scolex showing muscular structure of bothridia in lateral view.

Figures 16-18. Tetrabothrius alcae n. sp., showing structure of proglottids at progressive stages of ontogeny and positions of male and female organ systems from micrographs of whole-mounted specimens (scale bars in micrometers). Fig. 16. Proglottids in early maturity (holotype, 2640-1A), dorsal view, showing dextral position of genital pore, disposition of testes surrounding female system with gap in distribution along anterior margin of dendritic ovary and follicular vitelline gland. Fig. 17. Proglottids in maturity (paratype 018-75-A), ventral view, showing bilobed dendritic ovary and follicular anteroventral vitelline gland. Fig. 18. Proglottids in maturity (holotype, 2640-1A), dorsal view (poral aspect of segments from midline to marginal genital pore), showing position of testes, genital ducts relative to poral osmoregulatory canals, initial development of transverse uterine stem, and prominent dextral genital pore.

Figures 19-21. Tetrabothrius alcae n. sp., showing structure of female organ systems in ventral view from micrographs of a wholemounted specimen (scale bars in micrometers). Fig. 19. Structure of strongly dendritic and bilobed ovary (ov); highly elongate, follicular vitelline gland (vt); and granular uterine stem (ut) (paratype 018-75-A) in early maturity. Fig. 20. Ovary (ov), anteroventral vitelline gland (vt), and position of Mehlis' gland (me) (paratype 018-75-A) in maturity. Fig 21. Genital duct systems and transverse uterine stem (paratype 018-75-A) in region between poral wing of ovary (ov) and genital pore; note highly convoluted male vas deferens (vd), narrow vagina and expanding, elongate to pyriform vaginal seminal receptacle (vsr); and transverse uterine stem (ut) passing ventral to the poral osmoregulatory canals (osm) in maturity.

Figures 22-23. Tetrabothrius alcae n. sp., showing structure of genital atrium, cirrus sac, male atrial canal, and vagina from micrographs of a whole-mount specimen and hand-cut transverse sections in postmature to pregravid development (scale bars in micrometers). Fig. 22. Genital pore and atrium in dorsal view from whole mount (holotype 2640-1A), showing marginal position of the genital pore (ge); genital atrium (ga) with bilobed papilla; and prominent, strongly muscularized cirrus sac (cs). Fig. 23. Genital atrium in transverse section (holotype 2640-1C), viewed from posterior (dorsal to top), showing structure of cirrus sac (cs), genital atrium (ga), genital papillae, weakly curved male genital canal and position of atrial seminal receptacle (asr), and $90^{\circ}$ turn in vagina adjacent to the cirrus sac. Apertures of the male and ventrally disposed female canal open centrally and near the base of the genital papillae. The uterus (ut), vas deferens (vd), and vagina (va) pass ventrally to the dorsal (dosm) and ventral (vosm) osmoregulatory canals. Note the position, dimensions, and distribution of the inner (im) and outer (om) bundles of longitudinal musculature.

Figures 24-25. Tetrabothrius alcae n. sp., showing structure of genital atrium, cirrus sac, vagina, and genital ducts in transverse hand-cut sections, viewed from anterior, from micrographs of the holotype specimen (dorsal to top; scale bars in micrometers). Fig. 24. Genital atrium (holotype 2640-1C), showing relative positions of genital ducts, expanding uterus ventral to the osmoregulatory canals. Vagina, with thick wall and expanded atrial seminal receptacle (asr) enters genital atrium in $90^{\circ}$ turn; female canal opens ventral, not strongly adjacent, to orifice of male canal. Cirrus sac on lateral border of genital atrium with slightly curved male canal opening between weakly bilobed papilla in center of atrium. Fig. 25. Genital atrium (holotype 2640-1C), showing relationships of cirrus sac (cs) (containing highly convoluted vas deferens and retracted cirrus), genital atrium (ga) with male and female genital canals (arrows), genital papillae (gp), and atrial vagina.

Figures 26-29. Tetrabothrius alcae $\mathrm{n}$. sp., showing structure of gravid uterus from micrographs of whole-mounted specimens (scale bars in micrometers). Fig. 26. Uterus (paratype 2640-3C), dorsal view, showing strongly lobate, saccular structure (ut) during late development, extending beyond poral osmoregulatory canals to level of cirrus sac, genital pore (ge). Fig. 27. Gravid uterus (paratype 2640-3C), dorsal view (scale as in Fig. 26), showing completely developed, broad sacculate structure, at stage with fully developed oncospheres, extending to margins of proglottid. Fig. 28. Gravid uterus (paratype 2640-3G), dorsal view, showing position passing ventrally to poral osmoregulatory canals (arrows denote ventral osmoregulatory canal). Fig. 29. Uterine pore (paratype 2640-3C), dorsal view, showing developing dehiscence (arrows) on the midline near anterior margin of successive gravid proglottids. 


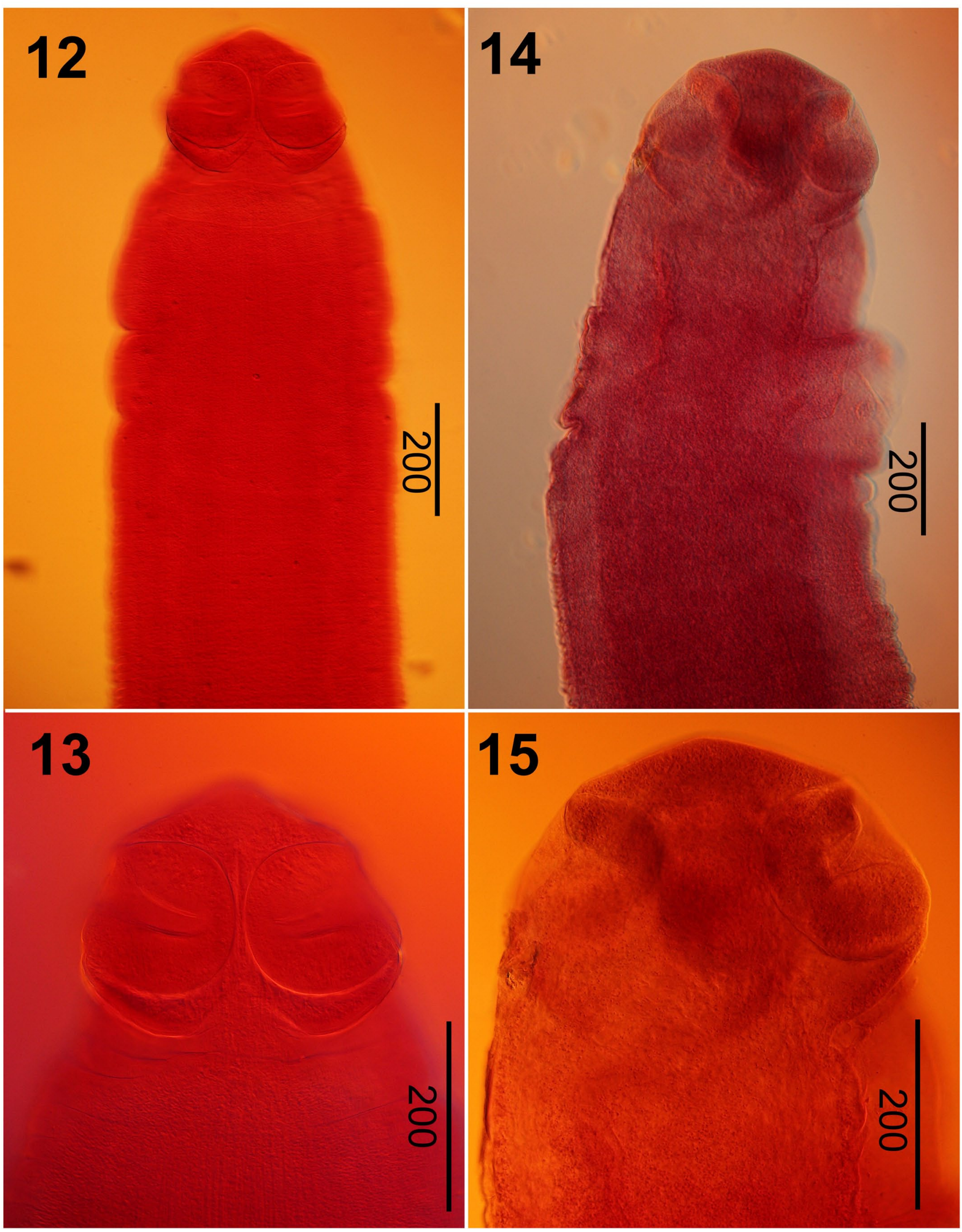




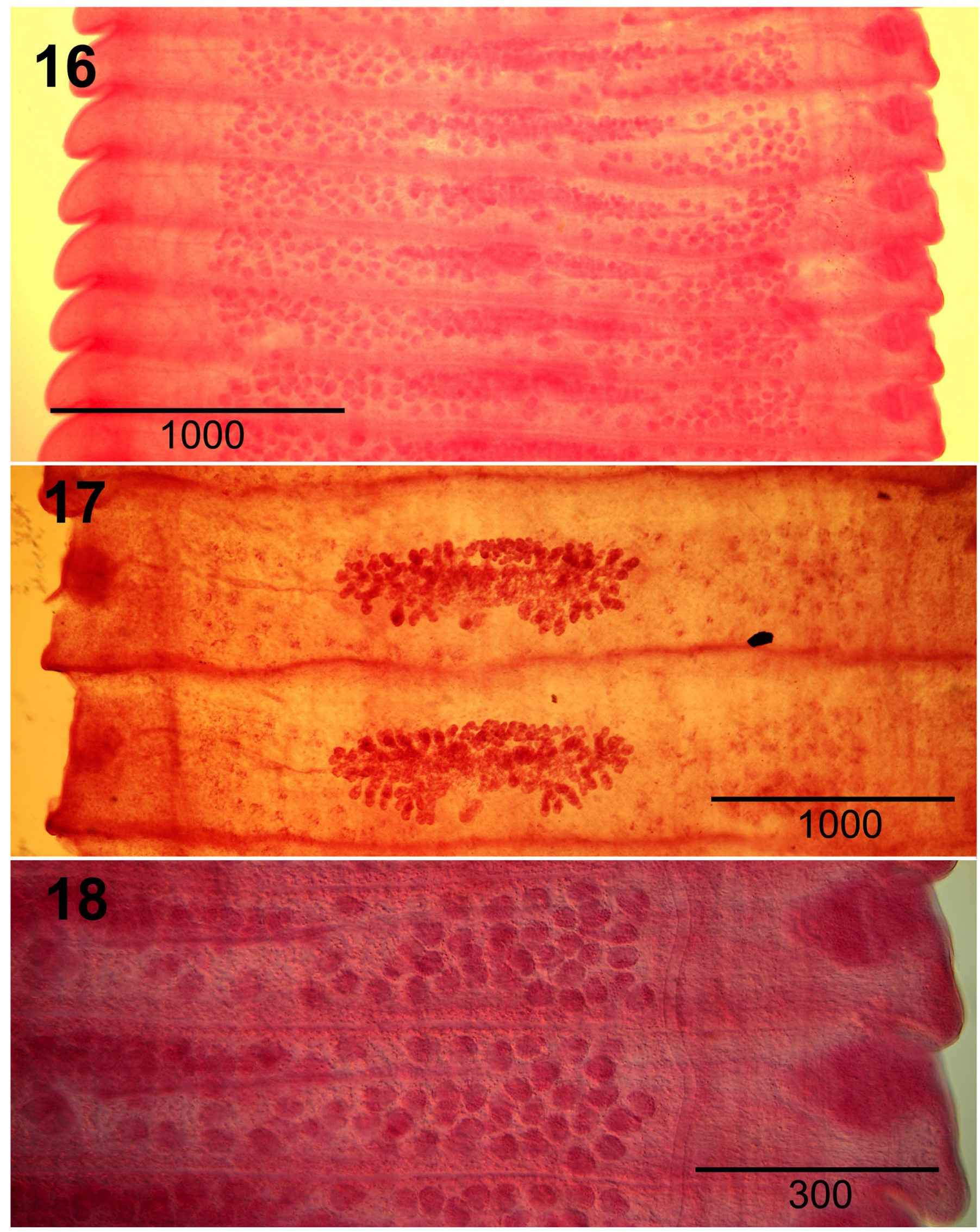




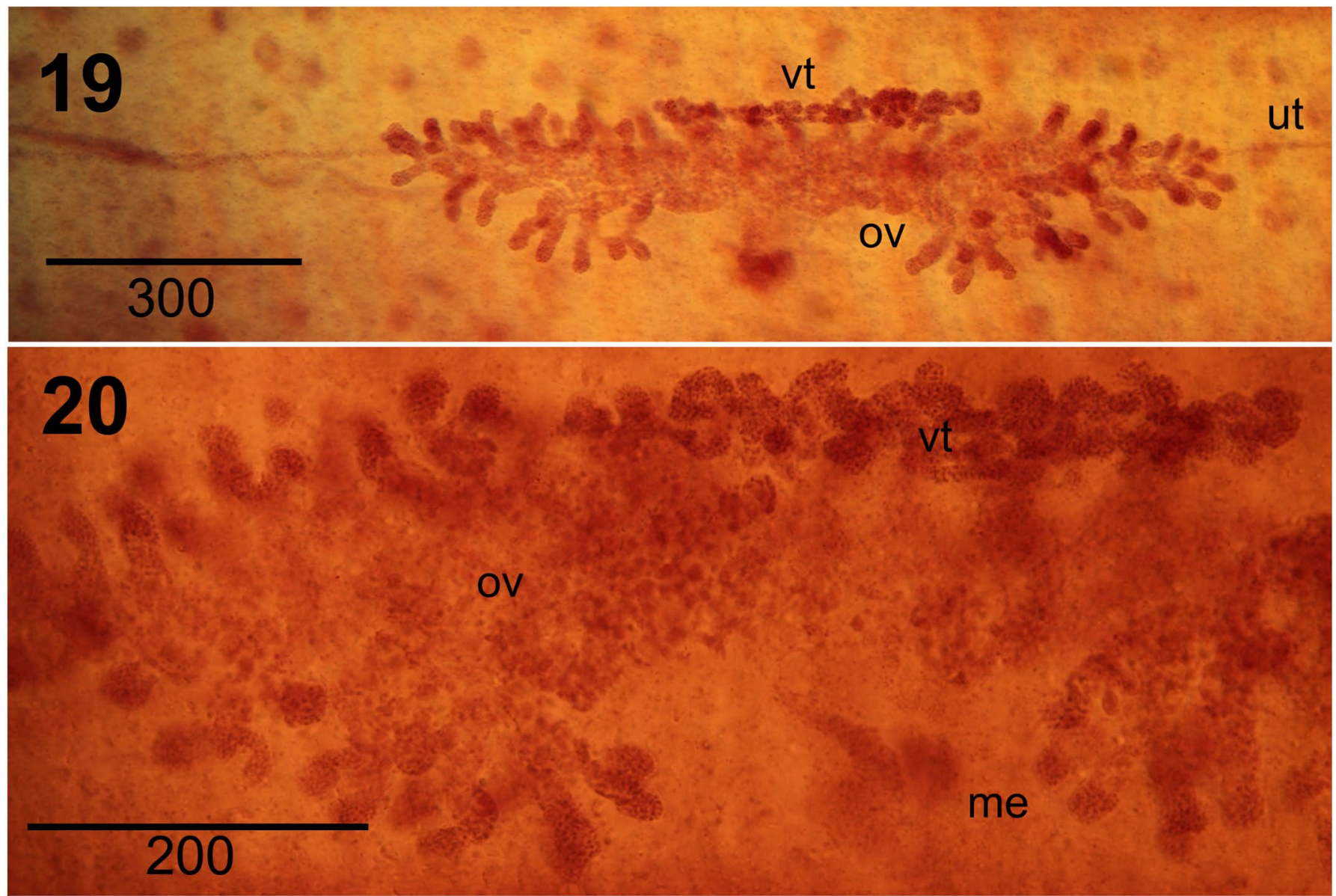

21

osm

vd

ut

VSr

ov 


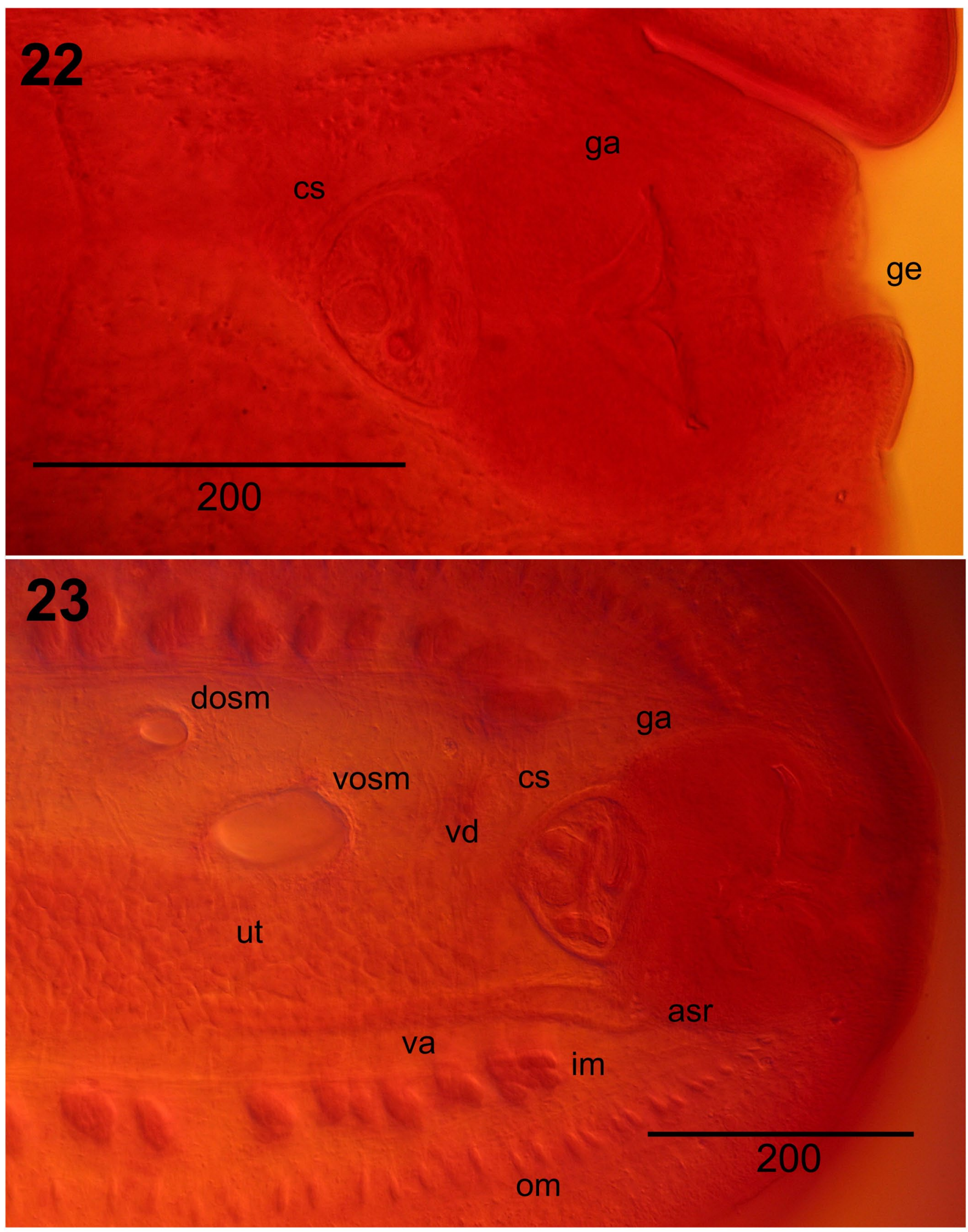




\section{4}




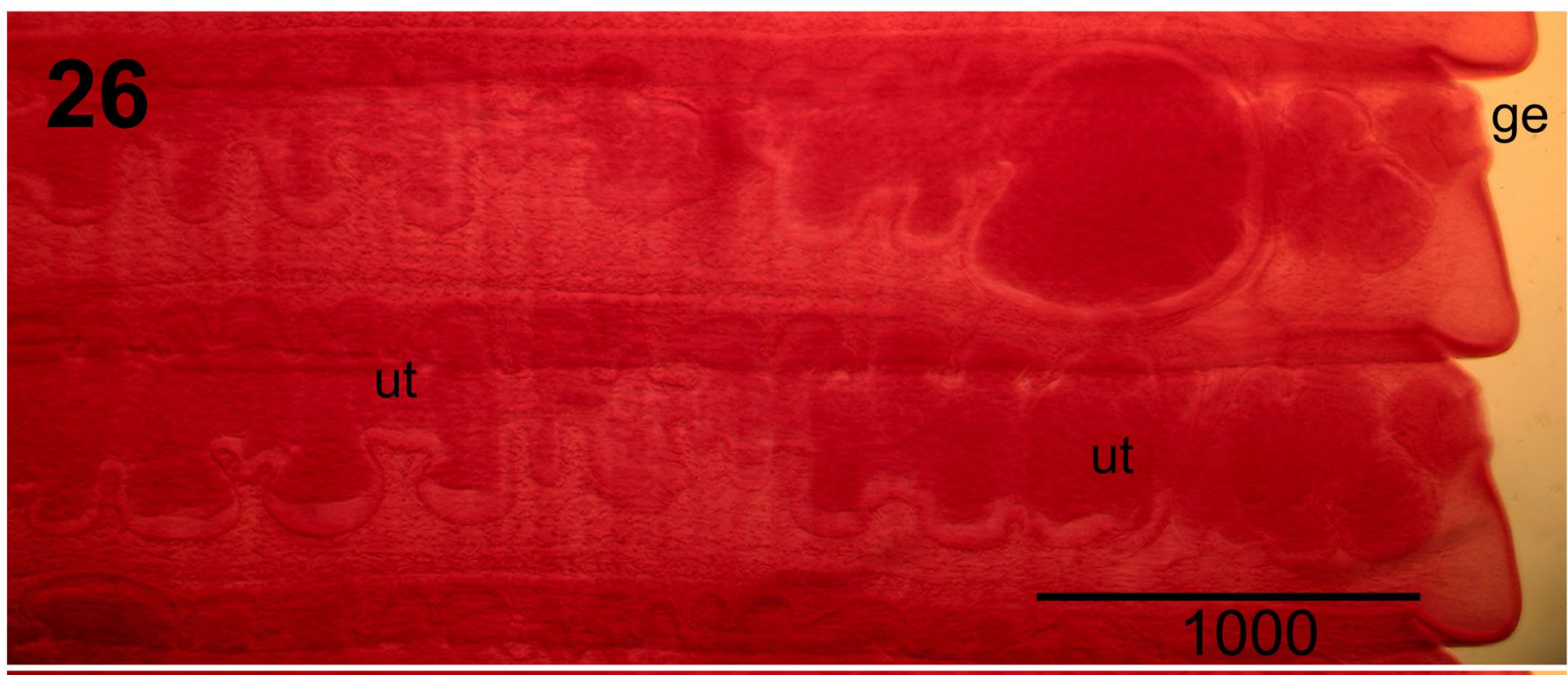

27

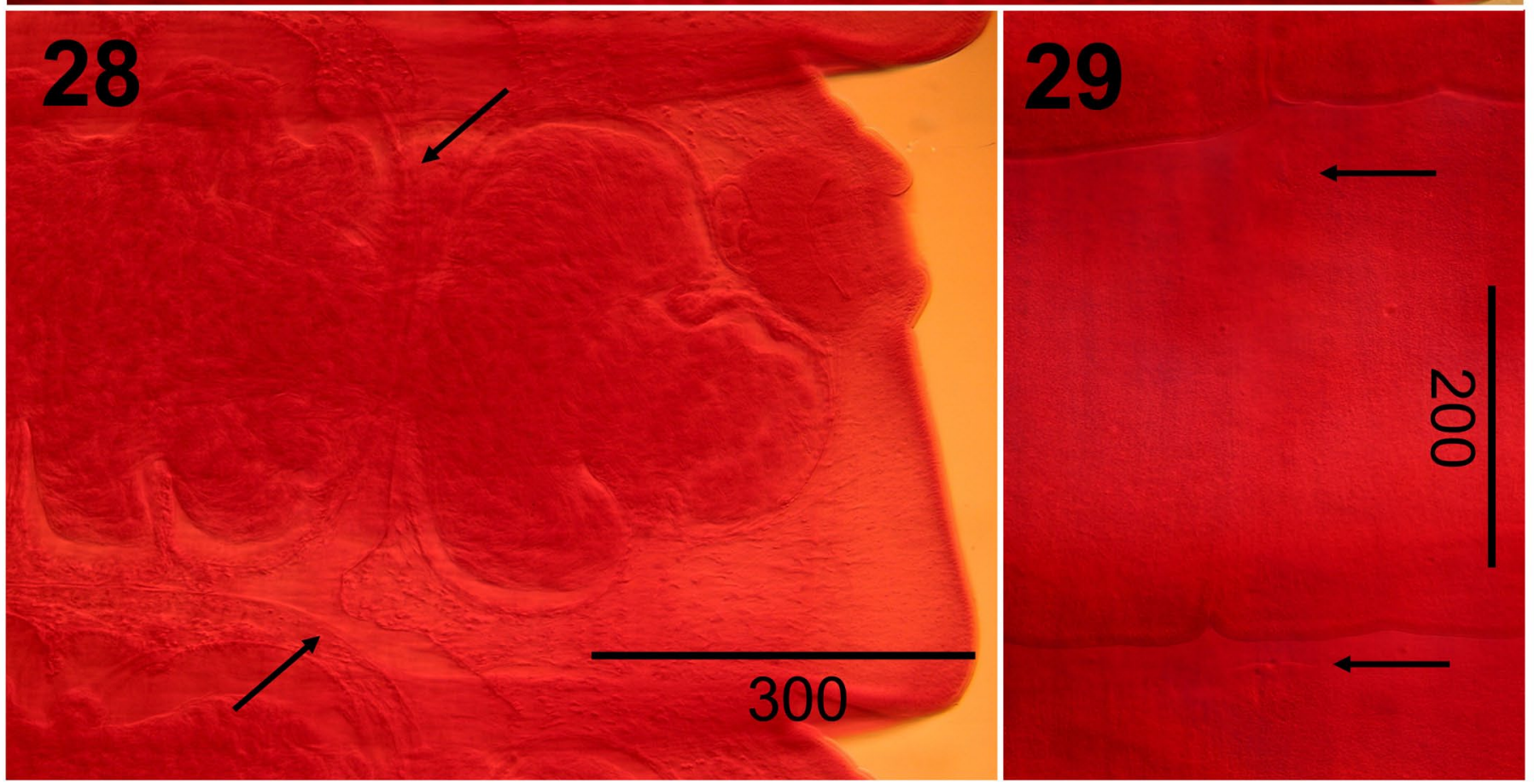


Female Genitalia: Ovary dendritic, multilobate, with 2 prominent wings, initially visible in 150th-170th segment; fully developed in 280th-330th segment; $(n=150) 892$ $1820(1,396)$ in width from early to late maturity; situated in anterior $2 / 3$ of segment with center of female organs (ovary and Mehlis gland) shifted slightly porad of midline; not extending to osmoregulatory canals. Vitelline gland extremely elongate, narrow, $(n=300) 301-1,018$ (556) wide $\times$ 52-156 (104) long; situated anteroventral to ovary, shifted under antiporal wing of ovary, with center of organ near midline; follicular structure with multiple reticulate, anastomosing ducts fusing to form broad common vitelline duct passing ventral to ovary. Common vitelline duct extends posteriad becoming confluent with common vaginal and ovarian duct to ventrally enter prominent Mehlis' gland, $(n=105)$ 52-94 (75) in diameter; nascent ascending, convoluted, uterine stem extends dorsally from Mehlis' gland. Proximal vagina terminates with expansion as thin-walled, ellipsoidal inner seminal receptacle receiving broad ovarian duct slightly dorso-lateral to Mehlis' gland. Vagina extends porad from internal seminal receptacle as thin tube dorsal to ovary, ventral to testes. Vaginal seminal receptacle develops as a voluminous, elongate, cylindrical to weakly pyriform, saccular dilatation of vagina with thin, membranous wall, extending from near level of poral wing of ovary (occasionally attains ovarian wing in pregravid), tapering porad, confluent with terminal vagina beyond level of osmoregulatory canals; maximum diameter and length $(n=40) 36-110(77) \times 520-1,350$ (869) (in 4 strobila) attained in mature to pregravid segments; sphincter demarking antiporal end. Distal vagina with thickened muscular wall, often expanded as atrial seminal receptacle, enters genital atrium in sinuous curve, ascending and at about $90^{\circ}$ ventral to cirrus sac. Female genital canal parallel to male duct, opening ventrally near base of weakly bilobed papilla; orifice ventral to aperture of male canal, not immediately adjacent; atrial vagina spinose. Ascending uterus extends anteriad from dorsal aspect of Mehlis' gland; transverse tubular uterine stem initially visible coinciding with ovarian development, dorsal to ovary, ventral to testes. Mature uterus, a broad, lobate, sacculate structure lined with cellular epithelium, situated dorsally in proglottid, extending ventrally beyond osmoregulatory canals, attaining margins of segment; gravid by 520th to 640th segment. Uterine pore median, initially visible dorsally as a miniscule dehiscence near anterior margin of proglottid on midline; patent in pregravid strobila; segments anapolytic. Mature eggs contained within irregular capsule with granular membrane. Hyaline embryophore elliptical $(n=50) 36-56(44)$ wide $\times 25-46$ long (34) con- tains oncosphere $(n=100)$ 28-45 (36) wide $\times 21-34(26)$ long. Embryonic hooks ( $n=50)$ 17-20 (18) for medial pairs, $(n=50) 20-21$ (20) for lateral groups.

\section{Taxonomic Summary}

Hosts: Type host-Common murre, Uria aalge (Pontoppidan, 1763). Other known hosts-Thick-billed murre, Uria lomvia (Linnaeus, 1758); ancient murrelet, Synthliboramphus antiquus (Gmelin, 1789); pigeon guillemot, Cepphus columba Pallas, 1811; and parakeet auklet Aethia psittacula (Pallas, 1769).

Localities: Type locality-Talan Island, northern Sea of Okhotsk, Russia, ca. $59^{\circ} 19^{\prime} \mathrm{N}, 149^{\circ} 06^{\prime} \mathrm{E}$, in type host on 25 July 1988. Other known localities-St. Lawrence Island, Alaska (Savoonga and Gambell); Cape Thompson, eastern Chukchi Sea, Alaska; Cape Lisburne, eastern Chukchi Sea, Alaska; St. Matthew Island, Bering Sea, Alaska; Buldir Island, western Aleutian Islands, Alaska; Pelagic waters south and adjacent to western Aleutian Islands; Kodiak Island (Chiniak Bay), Gulf of Alaska, Alaska; Ugaiushak Island, Gulf of Alaska, Alaska; Humboldt Bay, eastern North Pacific, California; Pelagic waters over Grays Marine Canyon, eastern North Pacific, Washington (Supplementary Data Tables 2-4).

Specimens: Holotype-in type host (subadult male), from type locality collected by E. P. Hoberg, A. la. Kondratiev, L. Kondratieva, and S. Bondarenko (field number 2640-1-A through 2640-1-G, single specimen on 7 slides including scolex, strobila, and hand-cut thick sections); identification by EPH. Museum of Southwestern Biology, Collection Catalogue No. MSB PARA-29629. Specific MSB PARA Collection data for paratype series and vouchers with georeferenced localities (linked to original field designations), hosts, dates, numbers of specimens (and slides), field collectors, and identifiers are summarized in Supplementary Data Table 4 and online in the Arctos database platform.

\section{Zoobank Name Registration for Tetrabothrius alcae: LSID urn:Isid:zoobank.org:pub: 35C7B2E7-DE5B-4E06-8640-29B948DBE4AF}

Symbiotype: Host specimens or tissues not retained and archived.

Etymology: Tetrabothrius alcae is derived from álka, denoting colonial diving birds in the Icelandic dialect obtained from Old Norse; northern hemisphere seabirds are now referred to the family Alcidae. 


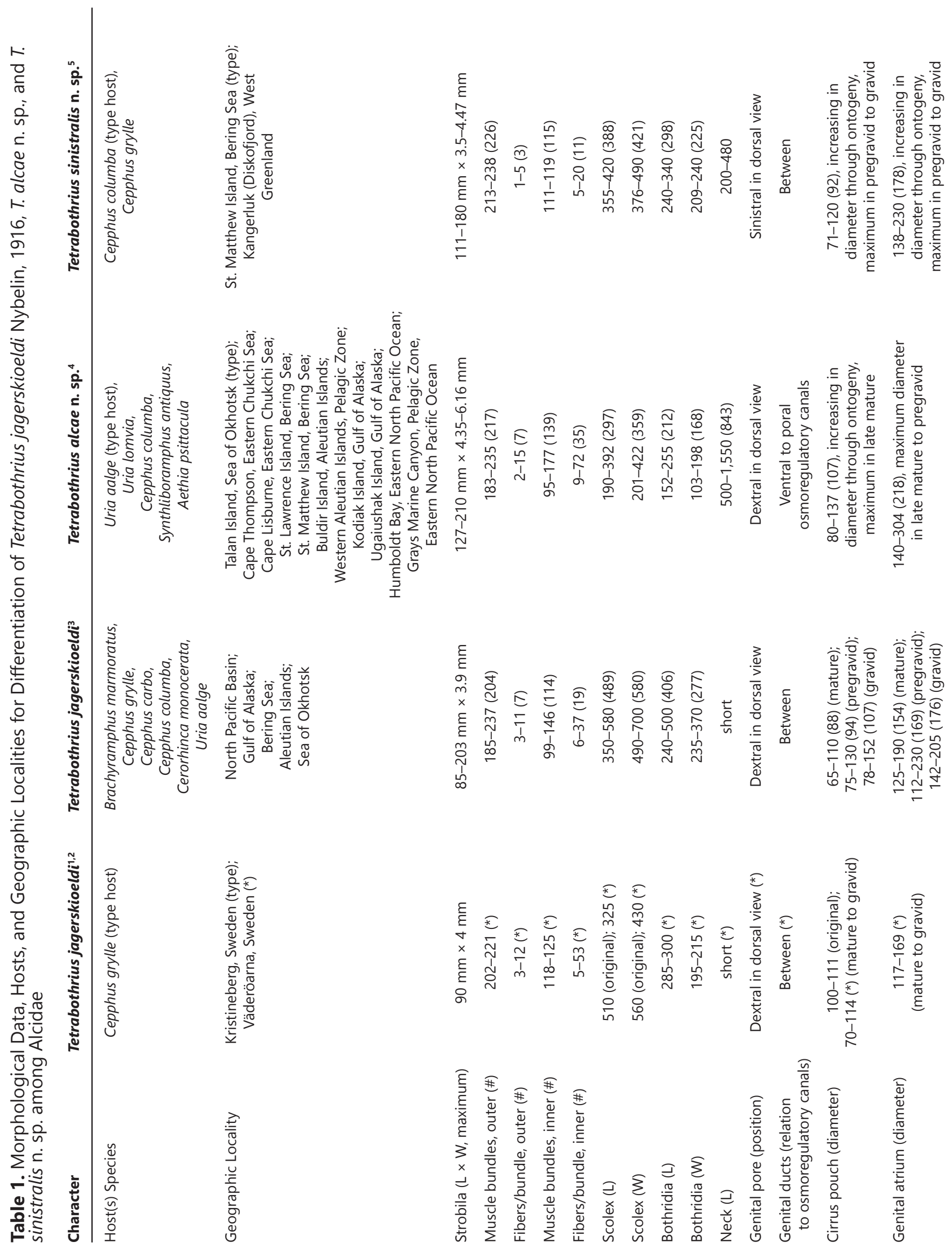




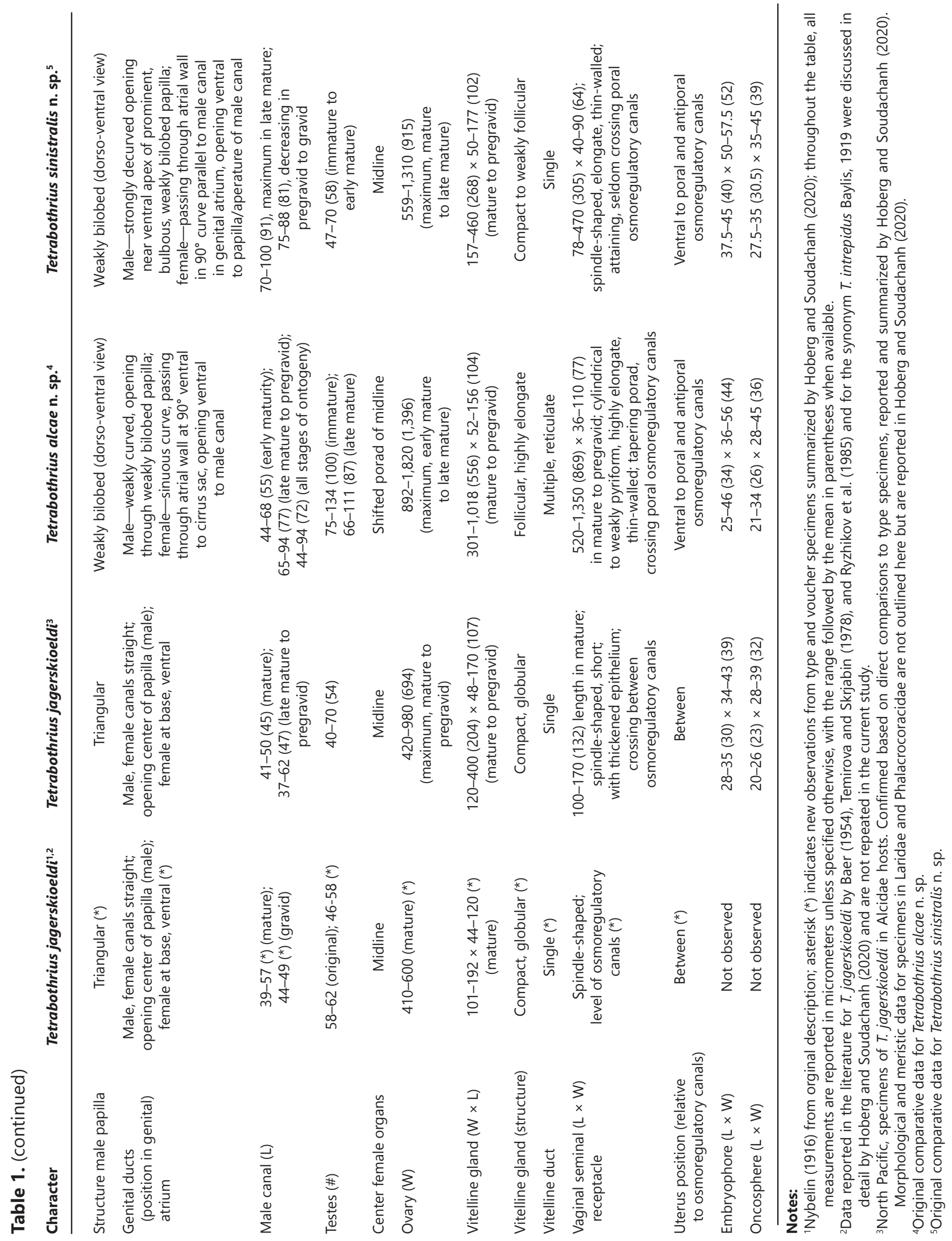




\section{Remarks and Diagnosis}

Among the 50 currently known nominal species in the genus (42 among avian hosts; 8 among mammalian hosts), specimens of Tetrabothrius alcae n. sp. are morphologically most similar to those of $T$. jagerskioeldi (see Mariaux et al., 2017; Hoberg and Soudachanh, 2020). Both species are characterized by a robust and large strobila and otherwise share considerable superficial similarity. A suite of structural and mensural characters allows unequivocal differentiation of these cestodes in the species-complex historically represented by $T$. jagerskioeldi. Specimens of T. alcae are distinguished from those of $T$. jagerskioeldi by attributes of the scolex; male and female organ systems; structure and dimensions of the vitelline gland; numbers of testes; configuration of the genital atrium; genital papillae and the male and female atrial canals; position of the genital ducts relative to the poral osmoregulatory canals; structure, dimensions, and position of the vaginal seminal receptacle; and dimensions of the embryophore and oncosphere, in addition to a broader array of characters. Some suites of characters-such as the structure and position of the vaginal seminal receptacle, relative positions of the poral osmoregulatory canals, and position of the female organs relative to the midline and structure of the vitelline gland-are applied for the first time in differentiation among species of Tetrabothrius (Table 1, Figs. 1-29; for $T$. jagerskioeldi, Supplementary Data File 5, Figs. 1-15) (Hoberg and Soudachanh, 2020).

The substantially smaller scolex of $T$. alcae possesses strongly developed, suckerlike bothridia with reduced auricles and a domelike, hypertrophied apical zone (Figs. 1-4; Figs. 12-15). In T. jagerskioeldi the scolex has typically broad, concave bothridia with strongly muscularized and prominent auricular appendages. The elongate and inflated neck region further contrasts with T. jagerskioeldi. Anastomoses of the osmoregulatory canals, observed in the scolex and neck region of $T$. alcae, are absent in T. jagerskioeldi. In T. alcae the dorsal osmoregulatory canals (poral) are shifted mediad relative to the ventral canals; in T. jagerskioeldi the poral canals are positioned equidistant from the proglottid margin.

Genital systems and organs are distinct in T. alcae. The genital ducts and uterine stem (and mature sacculate uterus) are consistently ventral to the osmoregulatory canals at all stages of development (Fig. 9; Figs. 23 and 25); in T. jagerskioeldi the ducts and uterus pass between the poral canals. The position of the center of the female organs (defined by the position of the Mehlis' gland, isthmus connecting the wings of the bilobed ovary, and vitelline gland) is shifted porad of the midline; in $T$. jagerskioeldi these systems reside on the midline of the proglottid. In T. alcae the developing and mature ovary is strongly dendritic, and the vitelline gland is highly elongate and follicular, with a reticulate anastomosing duct structure that coalesces into a single descending duct (Figs. 3-4, 10, 19-20); the mature ovary is multilobate, not dendritic, and a compact globular structure of the vitelline gland, whereas a single duct is typical in T. jagerskioeldi. In T. alcae the vaginal seminal receptacle (vsr) is highly elongate, expanded, cylindrical to pyriform, and sacculate with a thin wall, lacking epithelium, that extends from near the poral wing of the ovary to beyond the poral osmoregulatory canals (Figs. 3-4, 21); in T. jagerskioeldi the vsr is a spindle-shaped expansion, with a well-developed epithelium, that crosses between the dorsal and ventral osmoregulatory canals. In T. alcae the atrial seminal receptacle (a defined expansion contained in the wall of the genital atrium) is well developed; it is weakly developed in T. jagerskioeldi. In T. alcae the sinuous ascending vagina enters the genital atrium at $90^{\circ}$ to the cirrus sac and male atrial genital canal (Figs. 8-9, 23-25). In T. jagerskioeldi the terminal vagina is relatively straight entering the wall of the genital atrium, with the female genital canal becoming slightly curved in parallel to the cirrus sac and male canal. In gravid specimens, fully developed embryophores, oncospheres, and embryonic hooks are larger in T. alcae relative to those in T. jagerskioeldi.

Specimens of T. alcae have a substantially greater number of testes than T. jagerskioeldi. In T. alcae the numbers of testes are $>75$, maximum $=134$, mean determined in immature proglottids $=100$; overall from immature to pregravid proglottids $=96$. In specimens of $T$. jagerskioeldi among alcid, larid, and phalacrocoracid hosts, the range for numbers of testes was demonstrated as 40-73 (only exceptionally exceeding 60 in number) with a mean \pm 55 (Hoberg and Soudachanh, 2020). Testes surround the female organs laterally and to the posterior in T. alcae, with a gap in distribution directly anterior to the vitelline gland and ovary; distribution anterior to the female organs is without a gap in T. jagerskioeldi.

In T. alcae the male and female atrial genital canals are weakly curved ventrally (as observed in transverse sections), opening through a dorsally oriented, bilobed genital papilla; apertures of genital ducts are not in close proximity (Figs. 8-9, 23-25). Lateral muscular processes, directed ventrally bordering the genital papilla are absent; a single prominent, triangular genital papilla is absent. In T. jagerskioeldi the male and female genital canals are relatively straight, opening ventrally below the apex of a prominent triangular genital papilla; male and female canal apertures are adjacent. Lateral muscular processes are prominent (in transverse section, appearing as a dorsal bar in dorso- 
ventral view), extending ventrally and bordering the anterior edge of the genital papilla. The male atrial canal is substantially greater in length at all stages of ontogeny in specimens of T. alcae.

Among the series of specimens of $T$. alcae examined during our current study, we noted no variation in the ventral position of the genital ducts, transverse uterine stem, and fully developed gravid uterus. The typical position, among nearly all species of Tetrabothrius in avian hosts in which these characters have been documented is between the canals, as has been observed consistently in specimens of T. jagerskioeldi (e.g., Hoberg and Soudachanh, 2020) and in nearly all nominal species in the genus (Baer, 1954; Temirova and Skrjabin, 1978). A ventral position for the genital ducts relative to the osmoregulatory canals is rare among the 6 genera and 71 species of tetrabothriids, with inclusion of T. alcae (Mariaux et al., 2017). A ventral position for the ducts is apparent among species of Priapocephalus Nybelin, 1922, large cestodes of baleen whales (Hoberg, 1994). Among the 51 recognized nominal species of Tetrabothrius (8 among cetaceans, 43 among avian hosts with inclusion of T. alcae), a ventral position has been described in T. eudyptidis (Lönnberg, 1896) among sphenisciform birds and in T. arsenyevi Deliamure, 1955; T. egregius Skrjabin and Murav'eva, 1971; T. ruudi Nybelin, 1928; and T. schaeferi Markowski, 1955 among baleen whales. These 4 latter species, among a larger assemblage of cestodes in avian and cetacean hosts, have been provisionally referred to the subgenus Oriana Leiper and Atkinson, 1914 (see Mariaux et al., 2017). The placement of the genital ducts relative to the dorsal and ventral osmoregulatory canals thus appears to be a stable character contributing to species-level identity among tetrabothriids.

\section{Expanding Diversity in the T. jagerskioeldi- Complex, Cestodes in Guillemots}

Primary materials representing $T$. sinistralis n. sp. include specimens in 2 alcid hosts (single specimen in C. columba from the central Bering Sea and 2 specimens in C. grylle from West Greenland), with 3 cestodes on 6 slides in the type series on which the description is based (Supplementary Data Table 4); additional vouchers are not currently recognized. In the North Pacific basin, this species was found only in a pigeon guillemot (1 of 22, 4.5\%). Specimens attributable to $T$. sinistralis were not recognized among additional species of Cepphus, other alcids, nor a broader assemblage of marine birds, occurring in 1 of 1,345 alcid specimens examined ( $<1.0 \%$ ) from 1 of 55 localities (Supplementary Data Tables 2 and 3).

\section{Description-Tetrabothrius sinistralis $\mathbf{n}$. sp.}

Figures $30-49$

General Description: Large, robust, tetrabothriids; maximum length of strobila 111-180 mm, maximum width of 4,475 attained in pregravid segments; with $(n=2) 377-544$ proglottids in gravid specimens. Segments wider than long throughout strobila; $150-234$ long $\times 811-1,750$ wide in immature proglottids; $275-520 \times 1,261-4,100$ in mature (including early to postmature); $585-1,450 \times 3,500-4,425$ in gravid. Length:width ratio 1:3.88-9.0 in immature; 1:4.0410.8 in mature; 1:2.41-6.9 in pregravid to gravid. Scolex rectangular, wider than long $(n=3) 355-420$ (388) long $\times$ 376-490 (421) wide; auricles not prominent. Bothridia well developed, $(n=8)$ 240-340 (298) long $\times$ 209-240 (225) wide, flattened to concave with muscular margins; square across anterior margins of prominent auricles and bothridia. Apical region hypertrophied, domelike, expanded anterior to auricles. Neck, as measured from base of scolex to first indication of internal segmentation, short, 200-480 long $\times$ 365-450 wide. Ventral osmoregulatory canals 25-183 in diameter, width increasing posteriad in strobila; transverse canal 10-15, seldom with multiple anastomoses; dorsal canals 10-28 in diameter with limited variation throughout strobila. Dorsal canal overlies ventral canal. Genital pores unilateral, sinistral in dorsal orientation of strobila, marginal, situated in middle third of proglottid. Male and female genital ducts passing between poral osmogregulatory canals; transverse uterine stem and gravid uterus passing ventral to poral and antiporal osmoregulatory canals.

Longitudinal Musculature: Musculature prominent in transverse sections of proglottids; inner and outer bundles arranged in single layers. Inner bundles large in diameter; $(n=4) 111-119$ (115) in number; $(n=15)$ 5-20 (11) fibers per bundle. Outer bundles relatively small in diameter; $(n$ = 4) 213-238 (226) in number; $(n=15)$ 1-5 (3) fibers per bundle. Numbers of muscle bundles maximum in mature proglottids, diminishing in number posteriad in postmature and gravid segments.

Male Genitalia: Genital anlagen visible immediately posterior to neck, protandrous; first testes observed in 110th120th segment; male fully mature in 210th-250th segment. Testes positioned dorsally in 1-2 layers surrounding and partially overlapping female organs laterally and along 
posterior margin of ovary, gap in distribution of testes along anterior margin of ovary and vitelline gland; $(n=$ 90) 63-105 (80) in diameter. Testes $(n=45$ segments from 3 strobila) 47-70 (58) in number counted in immature to early mature segments. Vas deferens prominent, highly convoluted, distended adjacent to poral osmoregulatory canals. Cirrus sac ovoid, situated in dorsal aspect of genital atrium, ( $n=125) 71-120$ (92) in diameter overall across all stages of ontogeny, increasing in dimensions posteriad with progressive development, attaining maximum dimensions in late maturity. Cirrus sac diameter in maturity $(n=86)$ $71-120$ (88); in pregravid $(n=29) 79-120$ (100); in gravid ( $n=10$ ) 90-110 (101). Muscular wall of cirrus sac thickened, $(n=55)$ 7.5-18 (12). Cirrus sac contains extension of convoluted vas deferens and cirrus armed with miniscule but prominent spines. Genital atrium ovoid, highly muscularized $(n=145) 138-230(178)$ in diameter overall across all stages of ontogeny, attaining maximum diameter in pregravid to gravid. Genital atrium diameter in maturity $(\mathrm{n}=$ 105) 138-200 (168); in pregravid $(n=30) 171-230$ (201); in gravid ( $n=10$ ) 200-220 (205). Male genital canal, dorsal, extending through wall of atrium, strongly decurved ventrally to open subventrally near apex of prominent, bulbous, bilobed papilla in center of atrial lumen; sphincters not observed. Length of male genital canal increases with age of proglottid and development of genital atrium, attaining maximum in late maturity; $(n=9) 70-100(91)$; length in pregravid to gravid segments $(n=9) 75-88(81)$.

Female Genitalia: Ovary multilobate, with 2 prominent wings, ovarian development and transverse uterine stem visible in 145th-160th segment; ovary fully developed in 275th-320th segment; $(n=60)$ 559-1,310 (915) in maximum width increasing in dimensions from mature to pregravid proglottids; situated in anterior $2 / 3$ of segment with center of female organs on midline; not extending to osmoregulatory canals. Vitelline gland compact to weakly follicular, relatively narrow, 50-177 (102) long $(n=115) \times 157-460$ (268) wide, increasing in dimensions from mature to pregravid proglottids; situated anteroventral to ovary, with center of organ on midline; with single broad common vitelline duct passing ventral to ovary. Common vitelline duct extends posteriad becoming confluent with common vaginal and ovarian duct to ventrally enter prominent Mehlis' gland, ( $\mathrm{n}=$ 35) 39-75 (57) in diameter; nascent ascending, convoluted, uterine stem extends dorsally from Mehlis' gland. Proximal vagina terminates with expansion as thin-walled, ellipsoidal inner seminal receptacle, $(n=15) 55-71$ (81) in diameter in mature to late mature proglottids, receiving broad ovarian duct slightly dorso-lateral to Mehlis' gland. Vagina extends porad from internal seminal receptacle as thin tube dorsal to ovary, ventral to testes. Vaginal seminal receptacle (vsr) present as highly elongate, spindle-shaped expansion of vagina with thin, membranous wall, lacking prominent epithelium when fully developed; originating and extending mediad from near level of poral osmoregulatory canals, attaining but seldom crossing poral canals in late mature to pregravid condition, not attaining poral wing of ovary; tubular vagina with initial expansion of vaginal seminal receptacle near 275th segment; maximum diameter of vsr $(n=45) 40-90$ (64) wide $\times 78-470$ long (305); increasing in dimensions from mature to pregravid proglottids, rapidly diminishes in diameter from pregravid to gravid segments. Distal vagina with thickened muscular wall, enters genital atrium in sinuous curve about $90^{\circ}$, ascending ventral to cirrus sac. Female genital canal parallel to male duct, opening ventrally near base of bulbous bilobed papilla; orifice ventral to aperture of male canal, not immediately adjacent; expanded distally as well-developed atrial seminal receptacle; atrial vagina spinose. Ascending uterus extends anteriad from dorsal aspect of Mehlis' gland; transverse tubular uterine stem initially visible dorsal to ovary and ventral to testes coinciding with ovarian development. Initial tubular expansion in about 295th segment (in cestode specimen with 544 proglottids); first egg about 320th; lobate expansion of uterus about 390th. Nascent dorsal uterine pore visible about 410th segment, initially situated as ovoid protruding bulge and lengthwise dehiscence along midline near anterior margin of proglottid. Fully developed uterus, a broad sacculate structure lined with cellular epithelium, situated dorsally in proglottid, extending ventrally beyond osmoregulatory canals; gravid by 500th segment. Uterine pore median, dorsal, ovoid aperture $(n=5)$ 190-370 (236) in diameter when fully patent in gravid strobila; segments anapolytic; eggs released near 510th segment to termination of strobila leaving lobate sac largely devoid of eggs. Mature eggs contained within ovoid to irregular capsule with thickened granular membrane. Hyaline embryophore elliptical, $(n=30) 50-57.5(52)$ wide $\times 37.5-45(40)$ long, contains oncosphere $(n=30)$ 35-45 (39) wide $\times$ 27.5-35 (30.5) long. Embryonic hooks $(n=50) 16.5-22.5$ (19) in length for medial pairs, $(n=50)$ 17.5-24 (22) for lateral groups.

\section{Taxonomic Summary}

Hosts: Type host-Pigeon guillemot, Cepphus columba Pallas, 1811. Other known host(s)—black guillemot, Cepphus grylle (Linnaeus, 1758).

Localities: Type locality-St. Matthew Island, Central Bering Sea, Alaska, ca. $60^{\circ} 20^{\prime} \mathrm{N}, 171^{\circ} 00^{\prime} \mathrm{W}$ on 27 July 1982. Other known localities-Adjacent to Kangerluk (formerly, Diskofjord), West Greenland, ca. $69^{\circ} 29^{\prime} \mathrm{N}, 53^{\circ} 56^{\prime} \mathrm{W}$, on 27 July 1955. 
Figures 30-32. Tetrabothrius sinistralis n. sp. scolex and mature proglottid. Fig. 30. Scolex, dorsoventral view, in holotype specimen (1301) in Cepphus columba. Fig. 31. Scolex, dorsoventral view in paratype (108-60) in C. grylle; note expanded apical region and vestigial apical organ. Fig. 32. Proglottid in ventral view in mature region of strobila from paratype. Note sinistral position of genital pore and terminal genitalia (when in dorsal orientation), position of uterine stem ventral to osmoregulatory canals, and genital ducts passing between osmoregulatory canals.

Figures 33-36. Tetrabothrius sinistralis n. sp. genital atrium in whole mount and in transverse section and the fully developed egg with oncosphere. Fig. 33. Genital atrium, ventral view in whole mount in late maturity from paratype in Cepphus grylle (10860). Fig. 34. Genital atrium, ventral view in whole mount in pregravid condition (108-60). Fig. 35. Genital atrium in transverse section in late maturity from holotype in C. columba (1301). Note relative positions of the male and female genital ducts; strongly decurved male canal opening subventrally on weakly bilobed papilla. Fig. 36. Egg.

Figures 37-40. Tetrabothrius sinistralis n. sp., showing scolex and attributes of the genital atrium (scale bars in micrometers). Fig. 37. Scolex in dorsoventral view from whole-mounted specimen (holotype 1301-1A), showing bothridia and prominent muscularized auricles. Fig. 38. Proglottid margin in lateral view, transverse section from posterior, dorsal to top (holotype 13011B), showing sinistral genital pore (ge) and genital atrium (ga), with position of vas deferens (vd), vagina (va), and expanding uterus (ut) relative to dorsal (dosm) and ventral (vosm) osmoregulatory canals in late maturity. Cirrus sac (cs) on lateral border of genital atrium (ga), with strongly decurved male atrial canal (arrow) opens on subventral apex of prominent genital papilla (gp); aperture of female canal and vagina is adjacent and ventral. Fig. 39. Proglottid margin from transverse section, from posterior (holotype 1301-1D) in pregravid stage, showing sinistral genital pore, terminal genitalia, and position of sacculate, expanding uterus relative to osmoregulatory canals. Fig. 40. Proglottid margin from transverse section (holotype 1301-1D) in gravid stage, showing genital atrium (ga), terminal genitalia, and position of sacculate uterus (ut) ventral to osmoregulatory canals (osm).

Figures 41-43. Tetrabothrius sinistralis n. sp., showing proglottids at successive stages of ontogeny and positions of male and female systems, from a whole-mounted specimen in dorsal orientation (scale bars in micrometers). Fig. 41. Proglottids in immature strobila (holotype 1301-1A) showing distribution of testes with gap along anterior margins of vitelline gland and ovary. Fig. $\mathbf{4 2 .}$ Proglottids in early maturity (holotype 1301-1A) showing structure of ovary and vitelline gland. Fig. 43. Proglottids in maturity (holotype 1301-1B) showing region from near midline to marginal, sinistral genital pore (ge), including genital atrium (ga), cirrus sac (cs), transverse uterine stem (ut), and margin of ovary (ov).

Figures 44-45. Tetrabothrius sinistralis n. sp., showing male and female ducts in dorsal view with detail of cirrus pouch, genital atrium, and vaginal seminal receptacle (scale bars in micrometers). Fig. 44. Cirrus sac (cs), genital atrium (ga), and genital pore (ge) in dextral-lateral aspect of pregravid proglottid showing relative position of osmoregulatory canals (osm) and vaginal seminal receptacle (vsr) (holotype 1301-1A). Fig. 45. Expanded vaginal seminal receptacle attaining and extending between poral osmoregulatory canals in pregravid condition of segments, also showing ventral position of the uterus (ut) (holotype 1301-1A).

Figures 46-49. Tetrabothrius sinistralis n. sp., showing gravid proglottids from whole-mounted specimen in dorsal orientation (holotype 1301-1E) (scale bars in micrometers). Fig. 46. Gravid proglottids showing lobate saccular uterus, at stage with fully developed oncospheres, extending beyond osmoregulatory canals. Fig. 47. Uterine pore at stage of full patency (arrows), showing structure on midline near anterior margins of successive gravid proglottids. Fig. 48. Oncospheres contained within capsules and embryophores in passage through patent uterine pore. Fig. 49. Embryophores containing fully developed oncospheres showing medial and lateral hooks. 

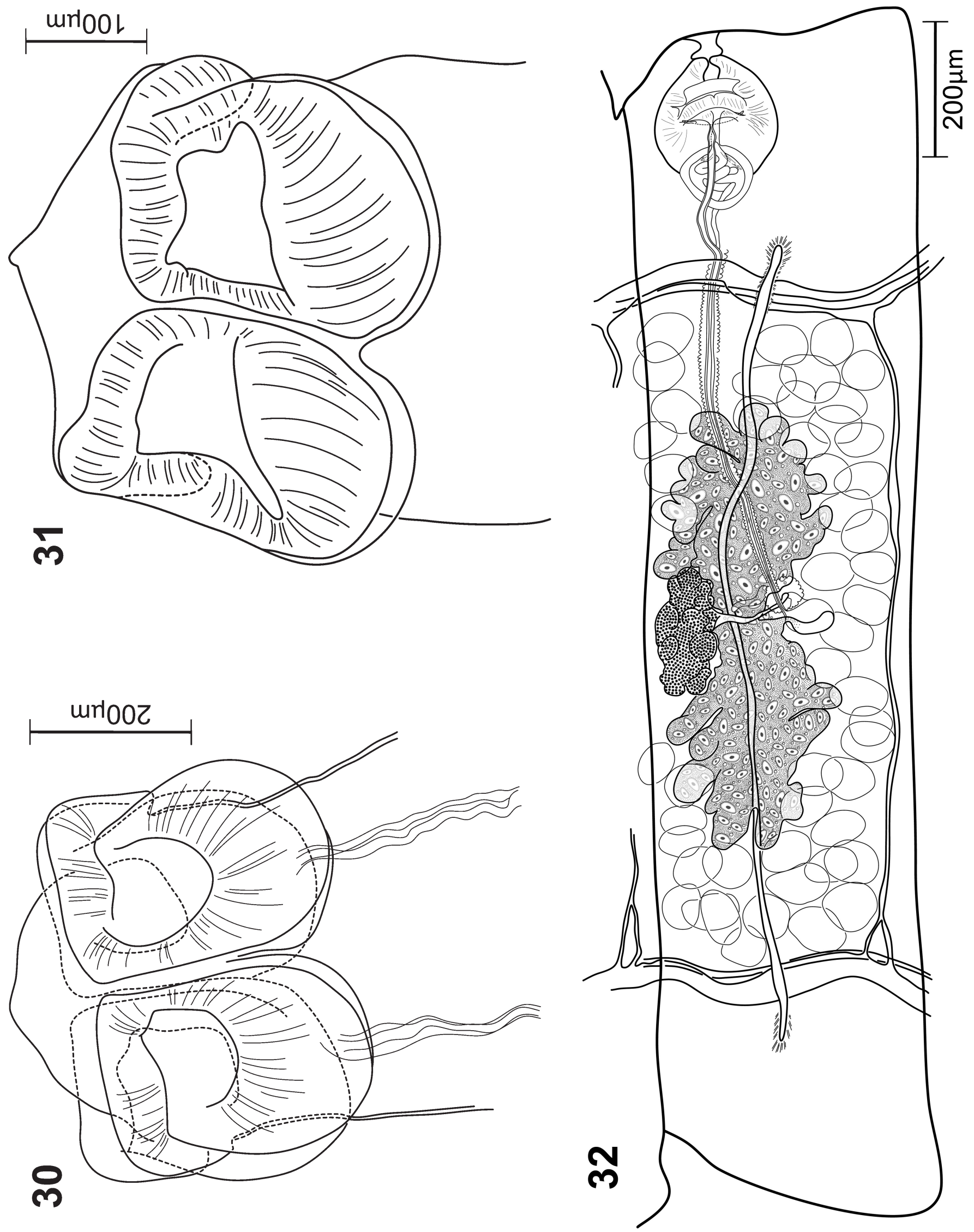


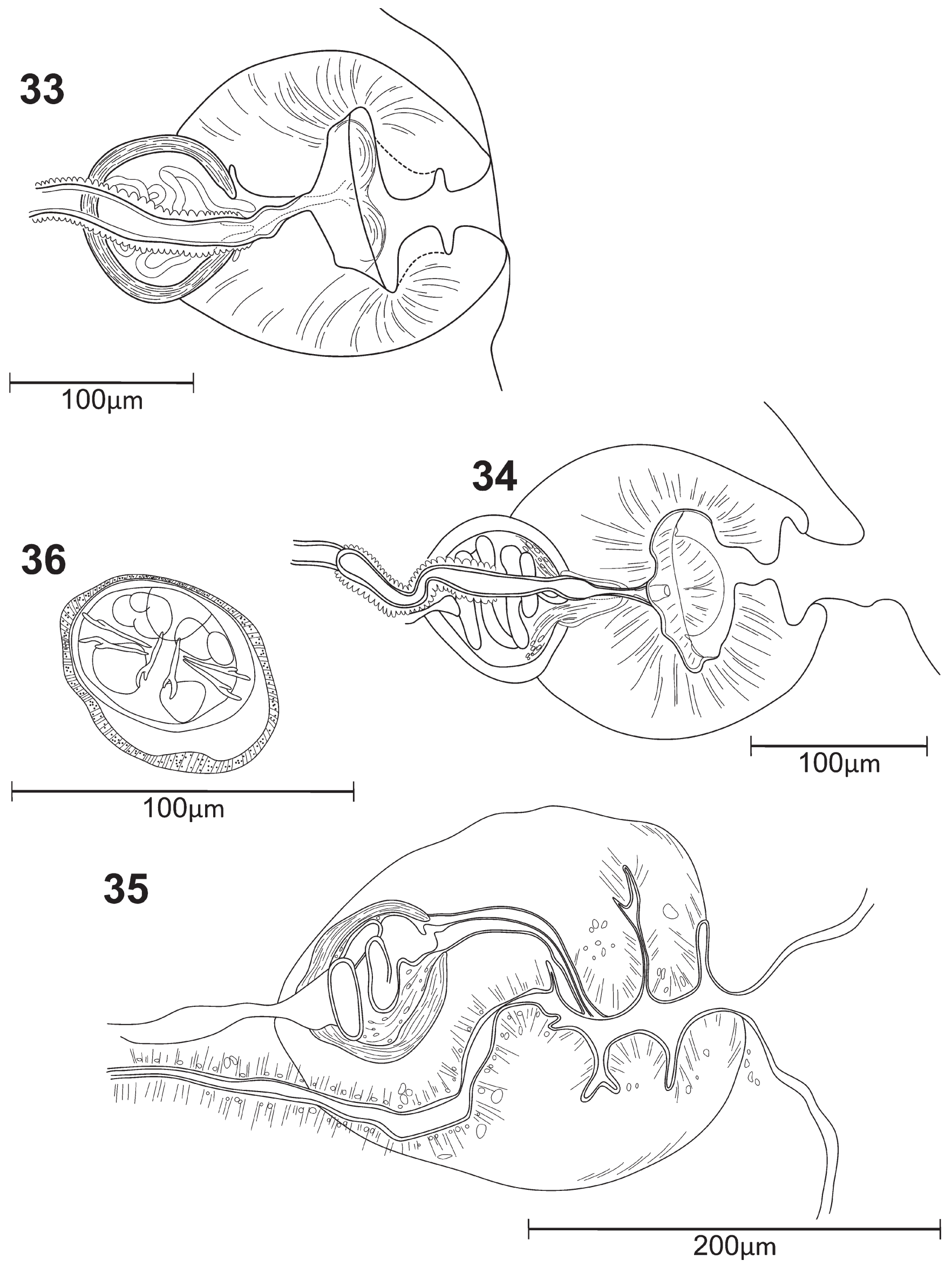




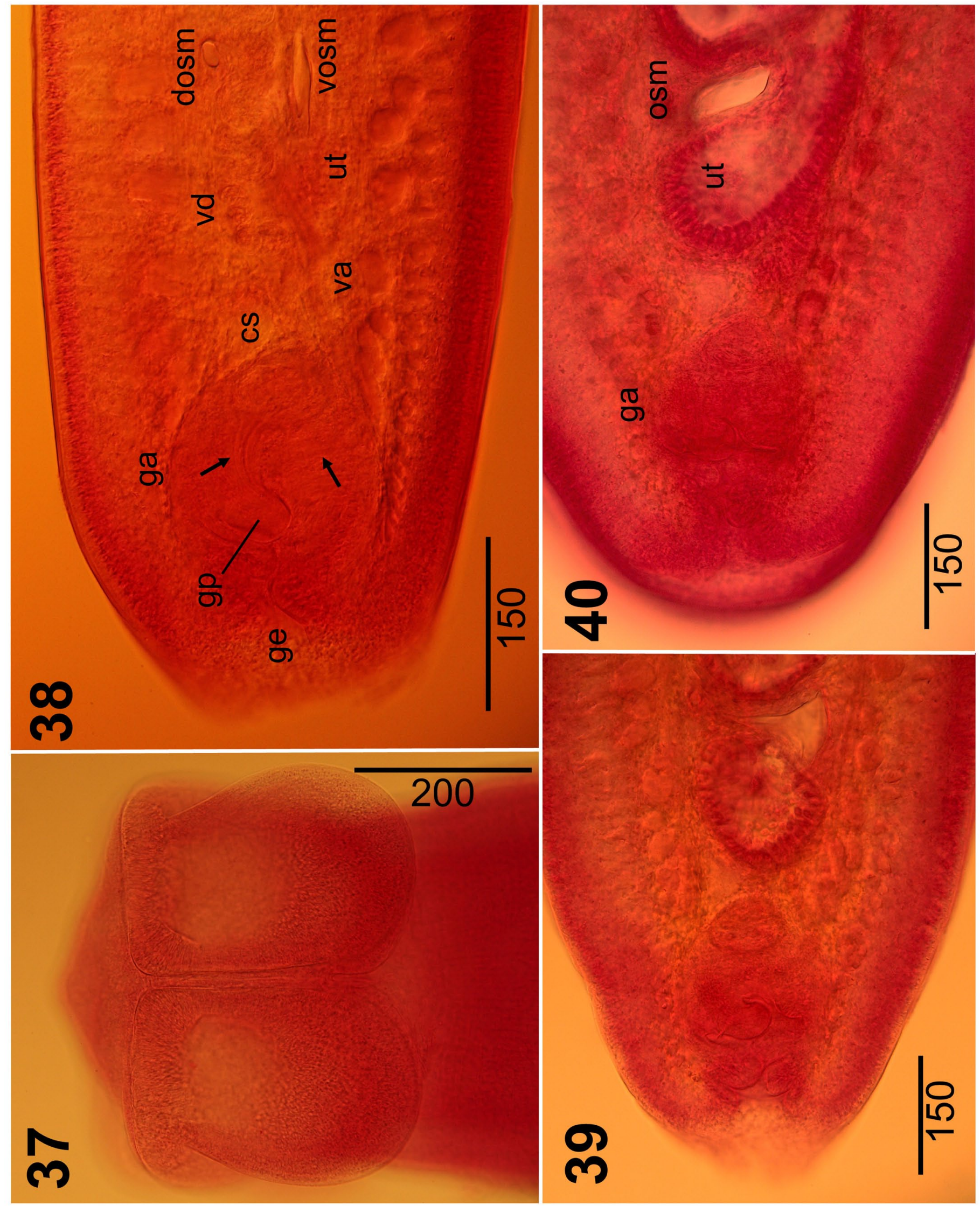



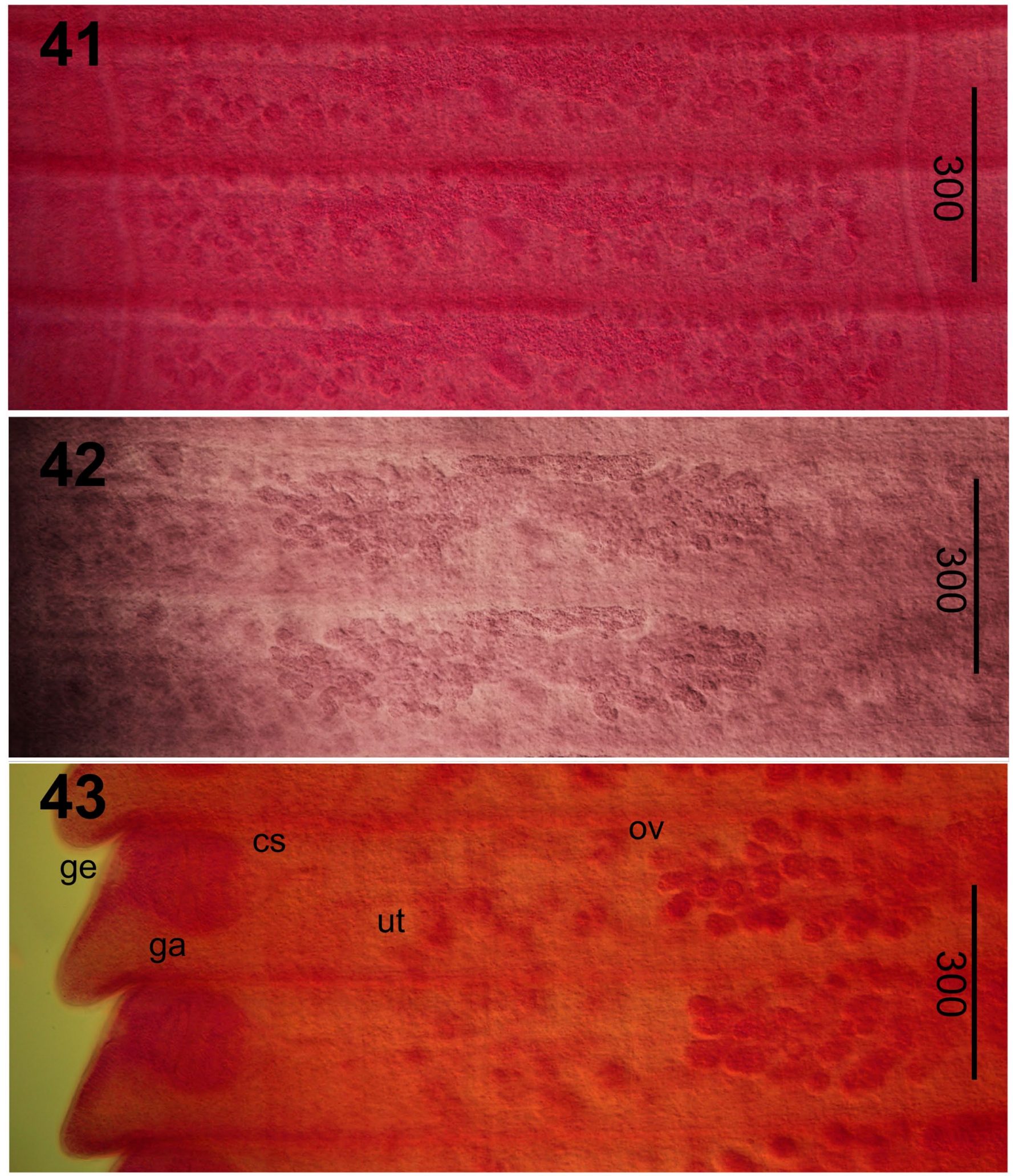


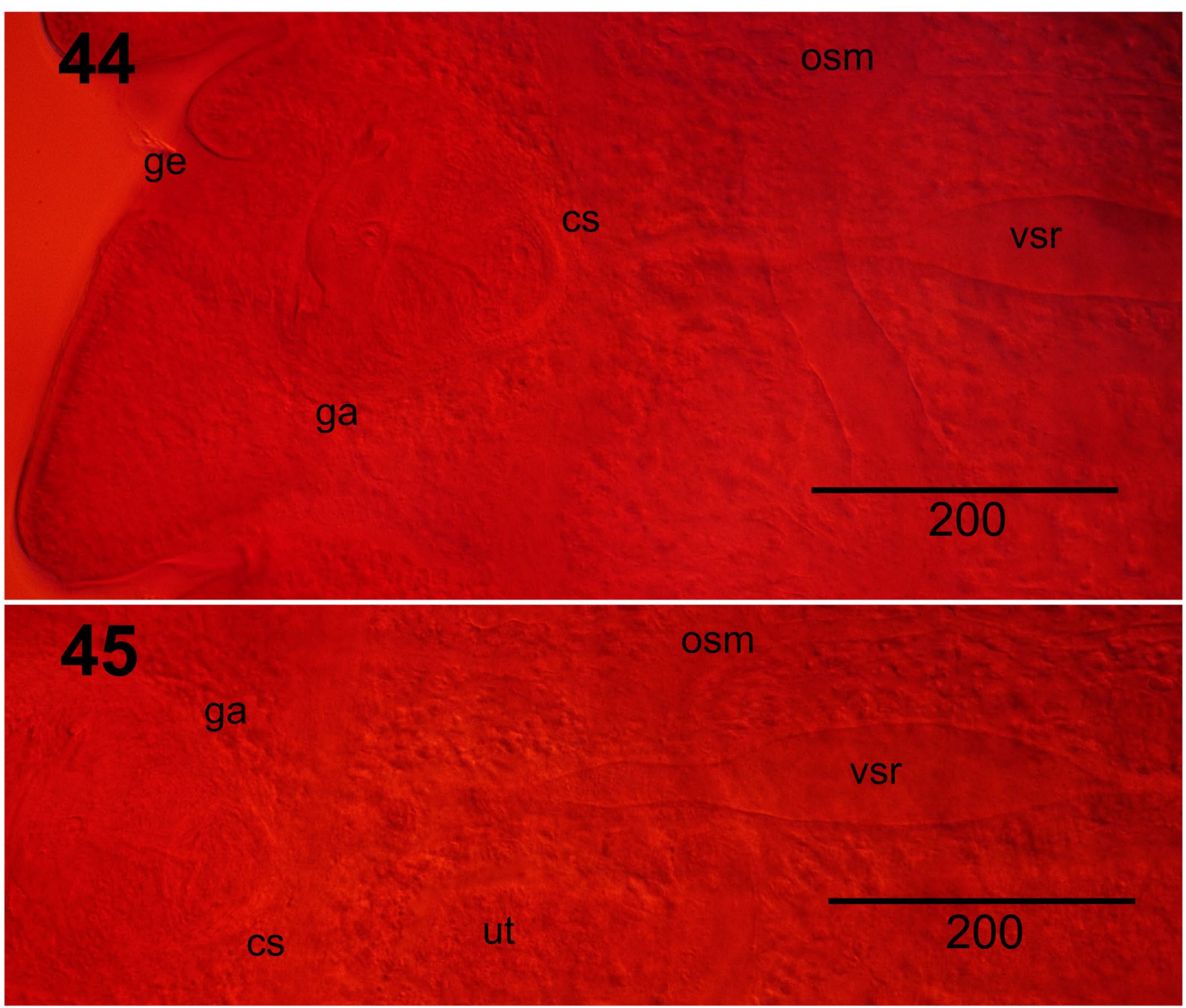




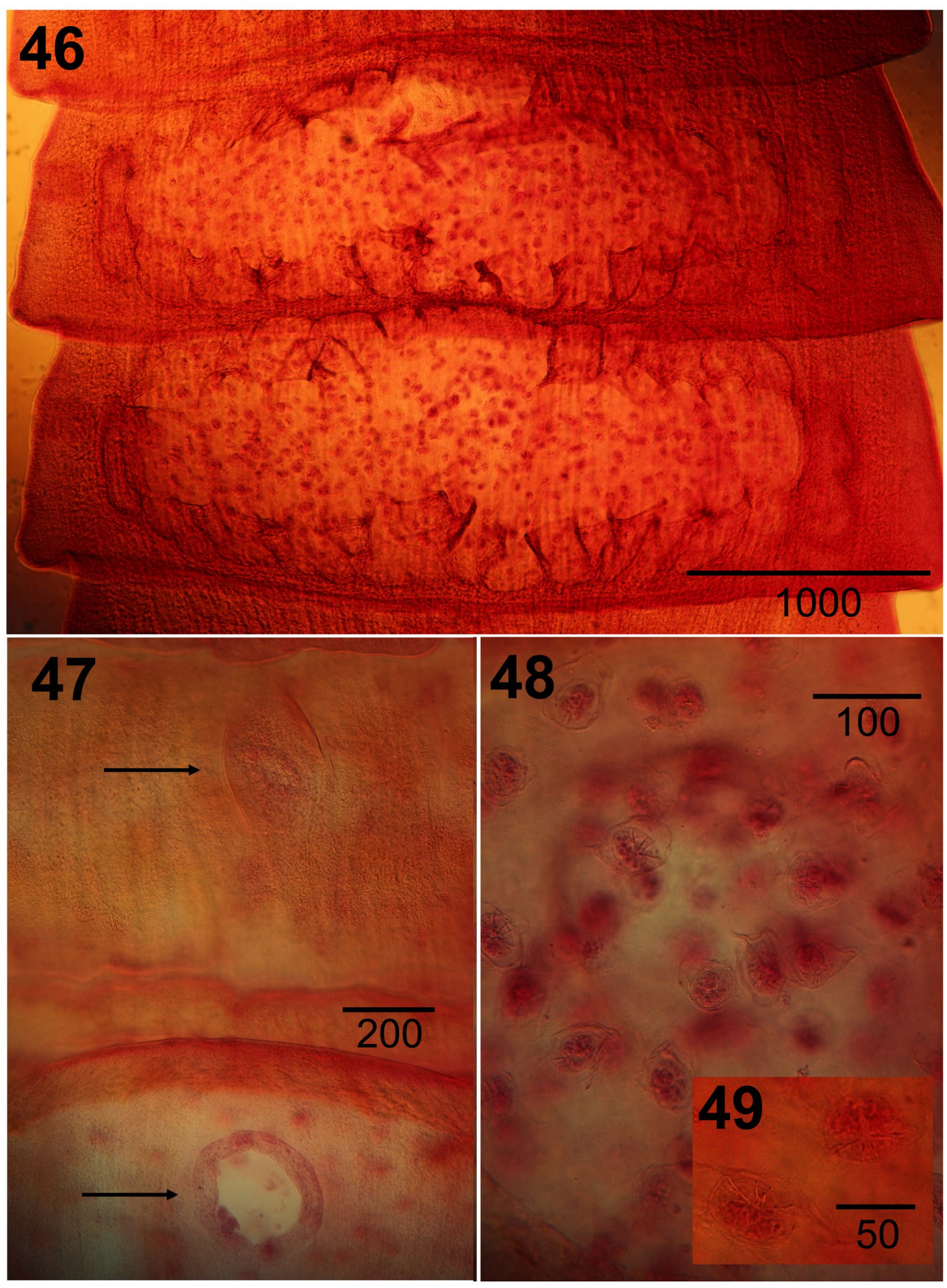


Specimens: Holotype-in type host (adult male), from type locality collected by E. P. Hoberg, (field number 1301-1-A through 1301-1-D; single gravid specimen on 5 slides including scolex, strobila, and hand-cut thick sections); identification by EPH. Museum of Southwestern Biology, MSB Collection Catalogue No. 29677. Paratype specimensParatype 1 and Paratype 2, including 2 complete specimens on 1 slide, formerly attributed to Tetrabothrius jagerskioeldi Nybelin, 1916, Museum d'Histoire Naturelle, Geneva (No. 108/60), from West Greenland collected by J. G. Baer on 27 July 1955; identification by EPH.

\section{Zoobank Name Registration for Tetrabothrius sinistralis: LSID urn:Isid:zoobank. org:act:23C47EF6-C595-4BB6-96AE-46C3ECB92AF2}

Symbiotype: Host specimens or tissues not retained and archived.

Etymology: Tetrabothrius sinistralis n. sp. is derived from sinistra in Latin and Medieval Latin, denoting the unique position of the genital pore "on the left side" of each proglottid in dorsal view.

\section{Remarks and Diagnosis}

Specimens of Tetrabothrius sinistralis $\mathrm{n}$. sp. are immediately distinguished from all species of Tetrabothrius, including 43 (with inclusion of $T$. alcae) and 8 congeners recognized respectively in avian and mammalian hosts. The sinistralmarginal position of the genital pore, in dorsal orientation of the strobila, contrasts with a dextro-marginal orientation which is observed among all nominal species. We note that Yamaguti (1935) reported irregular alternation in the position of the genital pore in some specimens of T. lari Yamaguti, 1935 (junior synonym of T. erostris Lönnberg, 1896). In those specimens, reversal of an otherwise dextral position occurred rarely in single segments or in short series of contiguous segments but did not consistently involve orientation in the entire strobila.

Among the current 44 nominal species in avian hosts, cestodes representing $T$. sinistralis are most similar to specimens of $T$. jagerskioeldi and $T$. alcae in overall dimensions of the strobila and scolex, with the latter being consistently wider than long. The numbers of testes are similar in $T$. sinistralis and T. jagerskioeldi, and the dorsal and ventral osmoregulatory canals (poral) are positioned with near equidistance from the proglottid margin. Relative to T. jagerskioeldi, specimens of $T$. sinistralis are distinguished by smaller dimensions of the scolex $(490-700 \mu \mathrm{m}$ in width among specimens of $T$. jagerskioeldi from the North Pacific), attributes of the genital atrium, genital papilla and ducts, position of the uterus, structure of the vitelline gland, and dimensions of the embryophore and oncosphere (Table 1; Hoberg and Soudachanh, 2020; for T. jagerskioeldi, Supplementary Data File 5, Figs. 1-15). Although the male and female genital ducts are positioned between the poral osmoregulatory canals in $T$. sinistralis and T. jagerskioeldi, the transverse uterine stem, and uterus at all stages of development in the former species, pass ventral to the canals (Figs. 32, 38-40, 45). In T. sinistralis the elongate, spindleshaped, thin-walled, vaginal seminal receptacle attains but seldom crosses the poral osmoregulatory canals (considerably smaller, thick-walled, and positioned between the canals in T. jagerskioeldi) and does not attain the ovarian wing (Figs. 44-45). The vitelline gland is weakly follicular and relatively elongate in $T$. sinistralis, contrasting with the compact and globular condition in T. jagerskioeldi (Figs. 41-42). The testes surround the female organs in T. sinistralis and T. jagerskioeldi, although there is a gap in continuous distribution along the anterior margin of the vitelline gland and ovary in the former species. The genital atrium in $T$. sinistralis is characterized by a bulbous, weakly bilobed, but prominent genital papilla and a ventrally directed, strongly decurved, male canal with a subventral aperture near the apex between the lobes (Figs. 35, 38-39); the aperture of the female genital canal is ventral to and adjacent to that of the male canal. The vagina enters the genital atrium in a $90^{\circ}$ curve in T. sinistralis; in T. jagerskioeldi the vagina attains a slight curve. In T. jagerskioeldi the male and female genital canals are relatively straight and parallel, opening ventrally below the apex of a single, prominent triangular genital papilla. The length of the male canal is substantially greater in T. sinistralis relative to T. jagerskioeldi. The embryophore and oncosphere are substantially larger in $T$. sinistralis.

Specimens of $T$. sinistralis and T. alcae are distinguished by dimensions and structure of the scolex and neck region; numbers of testes; position of the genital ducts; structure of the genital atrium, genital papilla, ducts, and distal vagina; and in the form and length of the vaginal seminal receptacle (Table 1). In T. sinistralis the scolex is flattened dorso-ventrally and possesses slightly concave bothridia with strongly developed auricles (Figs. 30-31, 37); the neck region is short. In contrast, T. alcae has powerfully muscular suckerlike bothridia with reduced auricles; the neck region is elongate and inflated. The dimensions of the scolex in $T$. sinistralis are notably larger. The position of the dorsal and ventral osmoregulatory canals is equidistant from the poral margin of the proglottid in T. sinistralis; the dorsal canal is shifted mediad in T. alcae (Figs. 35, 38). The male (vas deferens) and female (vagina) ducts pass between the poral osmoregulatory canals in T. sinistralis, and only the uterus is ventral in position. Alternatively, in T. alcae the 
genital ducts and the uterus are entirely ventral to the canals. The female organ systems are centered on the midline in T. sinistralis, whereas the center of the ovary and Mehlis' gland is shifted porad and the center of the vitelline gland is shifted to the antiporal ovarian wing in T. alcae. In T. sinistralis the ovary is lobate but not dendritic, and the vitelline gland is weakly follicular; in T. alcae the ovary is strongly dendritic, and the vitelline gland is highly elongate and follicular. The vaginal seminal receptacle is spindle-shaped and elongate in T. sinistralis, differing from the voluminous pyriform to cylindrical condition in T. alcae (Figs. 44-45). The numbers of testes are considerably fewer in specimens of $T$. sinistralis. Dimensions of the cirrus sac and muscular genital atrium overlap, although these organs tend to be smaller in specimens of $T$. sinistralis at comparable stages of development. The length of the male atrial canal overlaps between the species; however, the structure differs considerably. In $T$. sinistralis the male genital canal is strongly decurved ventrally, opening subventrally near the apex of a bulbous, weakly bilobed papilla (Figs. 35, 38-39). In T. alcae the male canal is weakly curved, opening near the base of a dorsally disposed bilobed genital papilla in the center of the atrium. In T. sinistralis and T. alcae the vagina passes through the wall of the genital atrium in a $90^{\circ}$ curve ventral to the cirrus sac.

Tetrabothrius sinistralis can also be distinguished from 4 additional species of Tetrabothrius that may circulate among larids and other seabirds, including some cestodes that have been sporadically reported among alcid hosts from the North Pacific basin and Holarctic seas (Linton, 1927; Belopol'skaia, 1952; Baer, 1954; Temirova and Skrijabin, 1978; see Hoberg and Soudachanh, 2020). Specimens of species discussed in this and the following paragraphs (and T. jagerskioeldi) all have well-developed scolexes that are consistently wider than long and with typical flattened to concave bothridia and prominent auricular appendages. Among these, specimens of $T$. sinistralis differ from T. cylindraceus Rudolphi, 1819 based on dimensions and structure of the strobila (highly serrate, $\pm 50 \mathrm{~mm}$ long for gravid specimens of T. cylindraceus) and scolex (about 250 $\mu \mathrm{m}$ wide), the numbers of testes (about 20), smaller dimensions of most organ systems, and the structure of the genital atrium (male and female genital canals are parallel and ventrally curved throughout the length and open on a prominent strongly decurved genital papilla) (Linton, 1927; Baer, 1954; Temirova and Skrjabin, 1978).

Specimens of $T$. sinistralis differ from those of $T$. erostris based on generally smaller dimensions in the latter for the scolex ( $280 \mu \mathrm{m}$ in width in T. erostris), genital atrium (140 $\mu \mathrm{m}$ greater diameter), cirrus sac (mean diameter $=80$ $\mu \mathrm{m})$, ovary (480 $\mu \mathrm{m}$, maximum width), and vitelline gland
(125-175 $\mu \mathrm{m}$, maximum width, compact and globular) and in having fewer testes $(37-40$, maximum $=50)$. The spindleshaped vaginal seminal receptacle is positioned between the poral osmoregulatory canals in T. erostris. The genital atrium is similar in these species, with the male canal being ventrally decurved and opening near the apex of a genital papilla (Baer, 1954; Temirova and Skrjabin, 1978).

Specimens of $T$. sinistralis differ from those of T. macrocephalus Rudolphi, 1819 based on a series of characters in the latter species including substantially longer strobila (maximum $300 \mathrm{~mm}$ in T. macrocephalus), larger scolex (1,020-1,420 $\mu \mathrm{m}$ in width), relatively smaller genital atrium (140-210 $\mu \mathrm{m}$, in greater diameter) and cirrus sac (range 57-75 $\mu \mathrm{m}, 86 \mu \mathrm{m}$ maximum, greater diameter), fewer testes (35-40 in number), short male atrial canal (64 $\mu \mathrm{m}$ in length), and a strongly compact vitelline gland. The muscular genital atrium lacks a prominent papilla, and the male (dorsal) and female (ventral) canals are parallel, straight, and open centrally in the atrium (Linton, 1927; Baer, 1954; Temirova and Skrjabin, 1978).

Specimens of $T$. sinistralis differ from those of $T$. morschtini Murav'eva, 1968 in reference to a series of characters in the latter, including a smaller strobila, a substantially larger scolex (mean $=580 \mu \mathrm{m}$, maximum $840 \mu \mathrm{m}$ in width in T. morschtini), smaller genital atrium (98-138 $\mu \mathrm{m})$ and cirrus sac $(75-90 \mu \mathrm{m})$, a strongly compact vitelline gland, and substantially fewer testes (32-34 in number). The vaginal seminal receptacle in T. morschtini is spindleshaped and elongate, and does not attain the poral osmoregulatory canals. The structure of the genital atrium is also similar to $T$. sinistralis where the male canal is decurved ventrally, opening near the apex of a bulbous genital papilla, with the aperture of the vagina ventral and adjacent (Murav'eva, 1968).

\section{Metacestodes and Scolex Ontogeny among Species of Tetrabothrius}

Among specimens of T. alcae, postlarval cestodes, ranging from a few primary immature proglottids to initial appearance of genital anlagen and protandrous development of the testes, were identified based on structural characteristics of the scolex and powerful suckerlike bothridia. Among specimens of $T$. sinistralis, structural characters associated with developing metacestodes in the definitive host were not recognized. Attributes of metacestode or postlarval scolexes in T. alcae were defined by an expanded apical region, vestigial pedicle, apical pore, and padlike to ovoid apical organ (Figs. 50-57); a terminal apical sucker was not 
observed in any specimens. Postlarval specimens, with minimal development, were collected from 16 adult hosts (8 U. aalge, 6 U. lomvia, 1 A. psittacula, and 1 S. antiquus) at sites spanning the North Pacific and Bering Sea (Sea of Okhotsk, Aleutian Islands, central and Northern Bering Sea, Gulf of Alaska, and eastern Pacific from Grays Marine Canyon to Humboldt Bay) (Figs. 50-57) (Supplementary Data Table 4). Additionally, cestode specimens with larval attributes and strobilization with minimal development of early mature proglottids were observed predominantly among chicks of common (8) and thick-billed murres (1) near the time of fledging prior to dispersal from nesting cliffs adjacent to marine habitats on Talan Island; and in an adult ancient murrelet in the pelagic zone south of the Aleutian Islands (Figs. 58-61). A pigeon guillemot chick at St. Lawrence Island was infected by a fully developed cestode. Adult strobilate and gravid cestodes in which the scolex retained larval attributes (including the holotype) were observed in 4 subadult or adult murres ( $U$. aalge and U. lomvia) at Talan Island and in pelagic waters south of the Aleutian Islands. The occurrence of postlarval specimens and strobilate cestodes with larval characters encompasses an extensive spatial distribution and among 5 species of alcids, indicating that the life cycle is broadly completed within the North Pacific ecosystem.

An ontogenetic progression associated with cestodes recently acquired in the definitive host accounts for the degree of development of the inflated apical zone, apical organ, and vestigial apical pedicle and dimensions of individual scolexes (e.g., Hoberg, 1987a; Galkin, 1987). Generally, these developing scolexes were consistently wider than long $(n=23 ; 170-370 \mu \mathrm{m}$ [mean $=293$ ] in length, 165-400 [297] in width) and in the most developed specimens approached dimensions observed in large strobilate and adult cestodes (e.g., Figs 1-2; Figs. 12-15). Bothridia were strongly muscularized and suckerlike with relatively inconspicuous auricular appendages, $(n=52) 125-280$ (205) in length and 75-190 (138) in width. An elongate, inflated neck region was typical, and varying degrees of primary strobilization were evident (Figs. 50-57; Figs. 58-61). Apical expansion or hypertrophy indicative of recent infection and accelerated development and strobilization were also observed in strobilate adult and gravid specimens of cestodes in the type and voucher series. (e.g., the holotype and associated paratypes from Talan Island).
An intact apical sucker was not observed among fully developed (strobilate) or immature specimens of $T$. alcae. A rudimentary pedicle and vestiges of this organ following loss of the apical sucker in the definitive host were observed in some specimens consistent with scolex ontogeny among other Tetrabothriidae (e.g., Galkin, 1987; Hoberg, 1987a, 1989; Hoberg and Ryan, 1989; Hoberg et al., 1991; Hoberg and Measures, 1995). A single apical sucker, and vestiges of the apical organ system, have been described in immature and fully developed strobilate cestodes among multiple genera and species of Tetrabothrius and Anophryocephalus Baylis, 1922 in avian and pinniped hosts. The occurrence of a fully developed apical sucker, or hypertrophied apical region with a pedicle, serves to further confirm the uniformity of an accelerated ontogenetic pathway within the Tetrabothriidae (Hoberg, 1994). The scolex of the metacestode in the intermediate host is undifferentiated, with a prominent muscular apical sucker at the apex of an unsegmented body of the plerocercoid (Hoberg, 1987a; Galkin, 1987). Structural characters of the bothridia are attained through rapid development of the adult scolex, coinciding with or following initial strobilization, secondary to establishment in the avian or mammalian definitive host. Among specimens of $T$. alcae, patterns of accelerated differentiation for the scolex and strobila are further indicated by already strobilate specimens of tapeworms occurring in young common and thick-billed murres at the time of fledging (near 15-18 days of age, 8 birds; about 20 days, 2 birds) as evident at Talan Island. The typical fledging time for murres is about 20-22 days (range in reported duration prior to departure, 16-30 days), with young birds leaving the cliff-face ledges prior to attaining capacity for flight (Harris et al., 1997; Harris and Birkhead, 1985; Boekelheide et al., 1990). Thus, acquisition of parasites occurs before young birds have departed colony sites and become established in marine environments, being dependent on prey (usually piscine; e.g., Boekelheide et al., 1990; Piatt et al., 2020), which serve as intermediate or possibly paratenic hosts, provided directly by adult birds (e.g., Hoberg, 1992a, 1996). Prey species diversity varies regionally; for example, in the Farallon Gulf system off California, juvenile rockfish (species of Sebastes Cuvier, 1829) are a dominant resource for developing chicks, whereas in the Bering Sea sandlance (species of Ammodytes Linnaeus, 1758) are essential (Ainley and Sanger, 1979; Ainley, 1990; Piatt et al., 2020). 
Figures 50-57. Tetrabothrius alcae n. sp. postlarval scolexes showing relative progression in development of the adult holdfast (scale bars in micrometers). Fig. 50. Scolex, dorsoventral view, during initial development in postlarval cestode in Uria aalge (299A), Chiniak Bay, Kodiak Island. Note extensive inflated apical region and apical organ, suckerlike bothridia in development with rudimentary auricular appendages and inflated neck. Fig. 51. Scolex, dorsoventral view, showing retention of apical pedicle and developing bothridia in U. aalge (362-78b) at Chiniak Bay, Kodiak Island. Fig. 52. Scolex, lateral view, showing development of suckerlike bothridia and retention of apical pedicle in U. aalge (362-78a) at Chiniak Bay, Kodiak Island. Fig. 53. Scolex, dorsoventral view, showing domed apical region with apical organ and pore (arrow) in Uria lomvia (103AB) at Ugaiushak Island, Gulf of Alaska. Fig. 54. Scolex, dorsoventral view, showing apical organ and pore (arrow) in U. lomvia (1389), St. Matthew Island, Bering Sea. Fig. 55. Scolex, dorsoventral view, showing enlarged apical region and apical organ and muscular, suckerlike bothridia in Aethia psittacula (2723-2) at Talan Island. Fig. 56. Scolex, lateral view, showing domed apical region of holdfast and muscularized suckerlike bothridia in U. aalge (2440-2) from Grays Marine Canyon, eastern North Pacific. Fig. 57. Scolex, lateral view, with domelike apical region, padlike apical organ with pore (arrow), and strongly muscularized bothridia with rudimentary auricles in A. psittacula (2723-3) at Talan Island.

Figures 58-61. Tetrabothrius alcae n. sp. early strobilate cestodes (development to early maturity, with primary terminal proglottid) in dorsoventral view. Scolexes retain characteristics of postlarval specimens. Fig. 58. Scolex in early mature strobilate cestode retaining a primary proglottid in $U$. aalge, a chick near fledging (2660) at Talan Island. Note ovoid apical organ with padlike structure and apical pore (arrow) with muscular suckerlike bothridia. Fig. 59. Scolex in early mature, strobilate cestode. Note inflated neck region lacking segmentation and deep, muscular bothridia with poorly developed auricles, in U. aalge (2658-2), a chick near fledging at Talan Island. Fig. 60. Scolex in early mature, strobilate cestode, in U. aalge (2659-3), a chick near fledging at Talan Island. Note broad, dome-shaped apical region and retention of padlike apical organ and pore. Fig. 61. Scolex in lateral view, early mature, strobilate cestode, in U. aalge (2657-3) at Talan Island. 


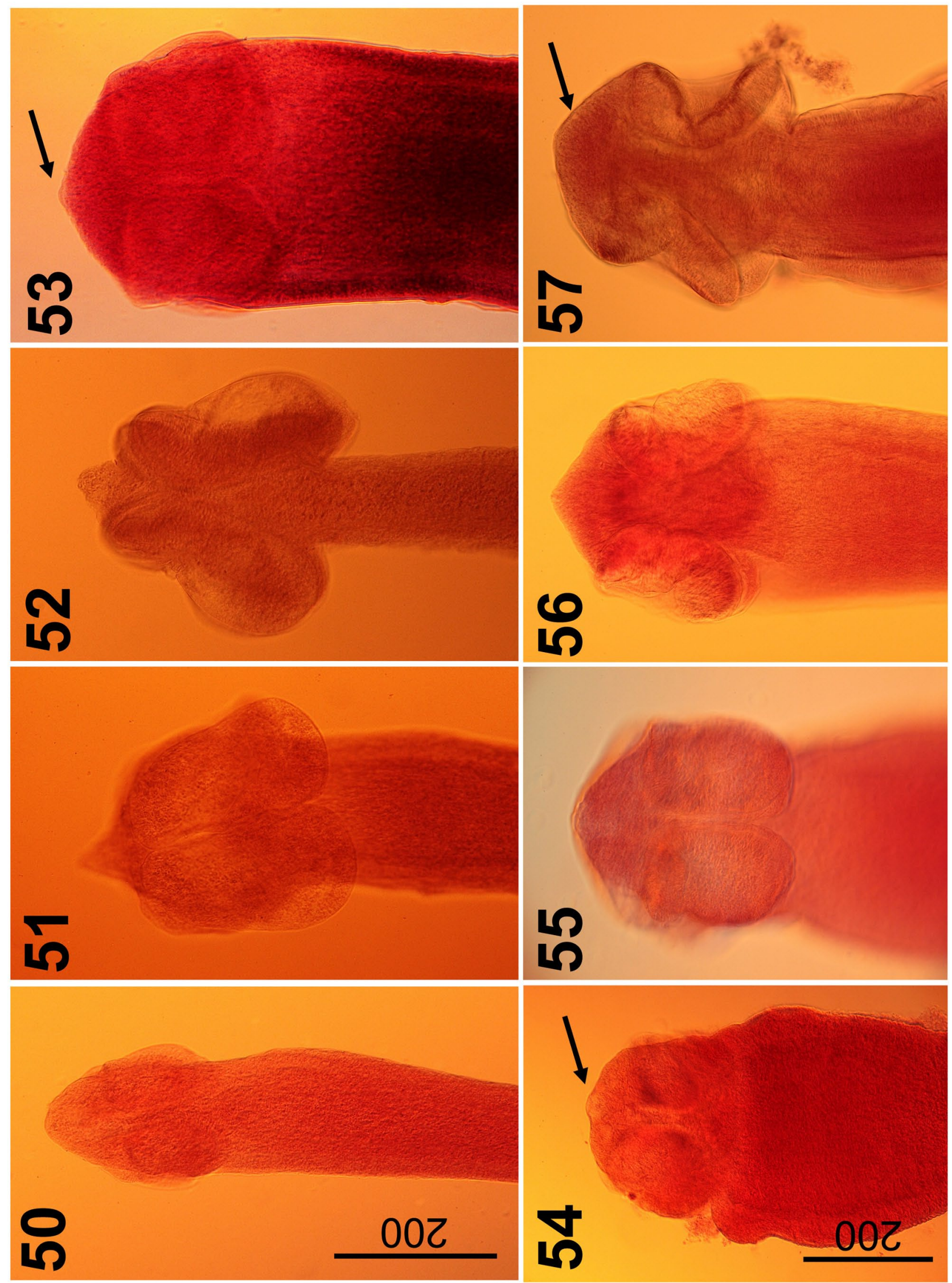



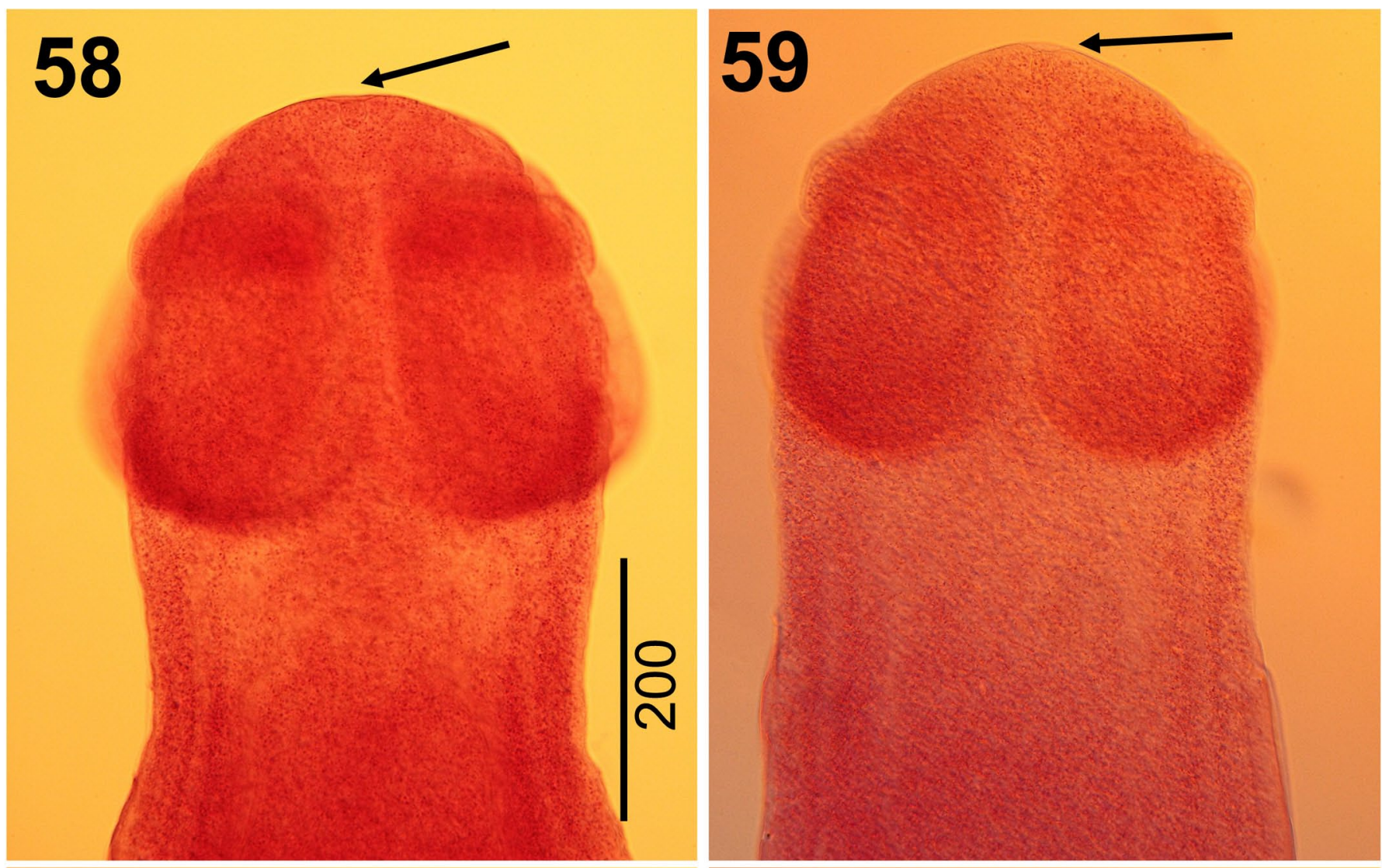

\section{0}

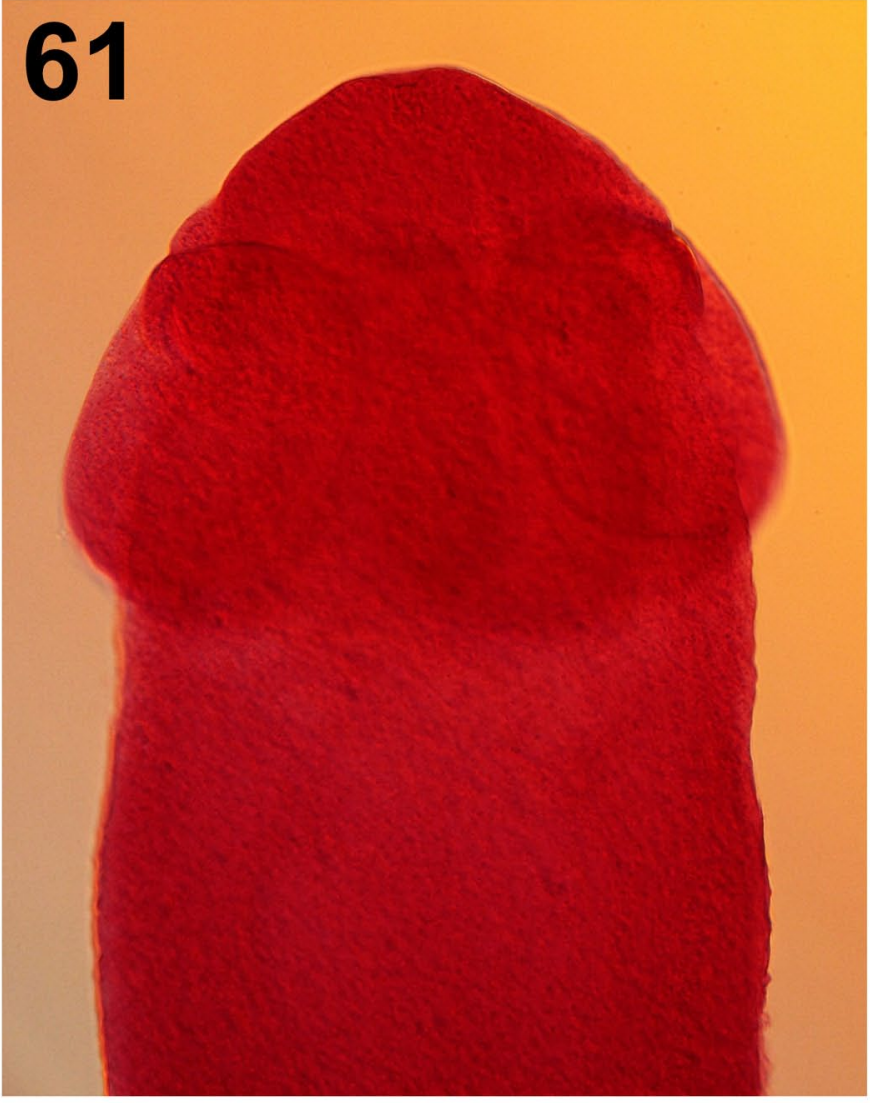




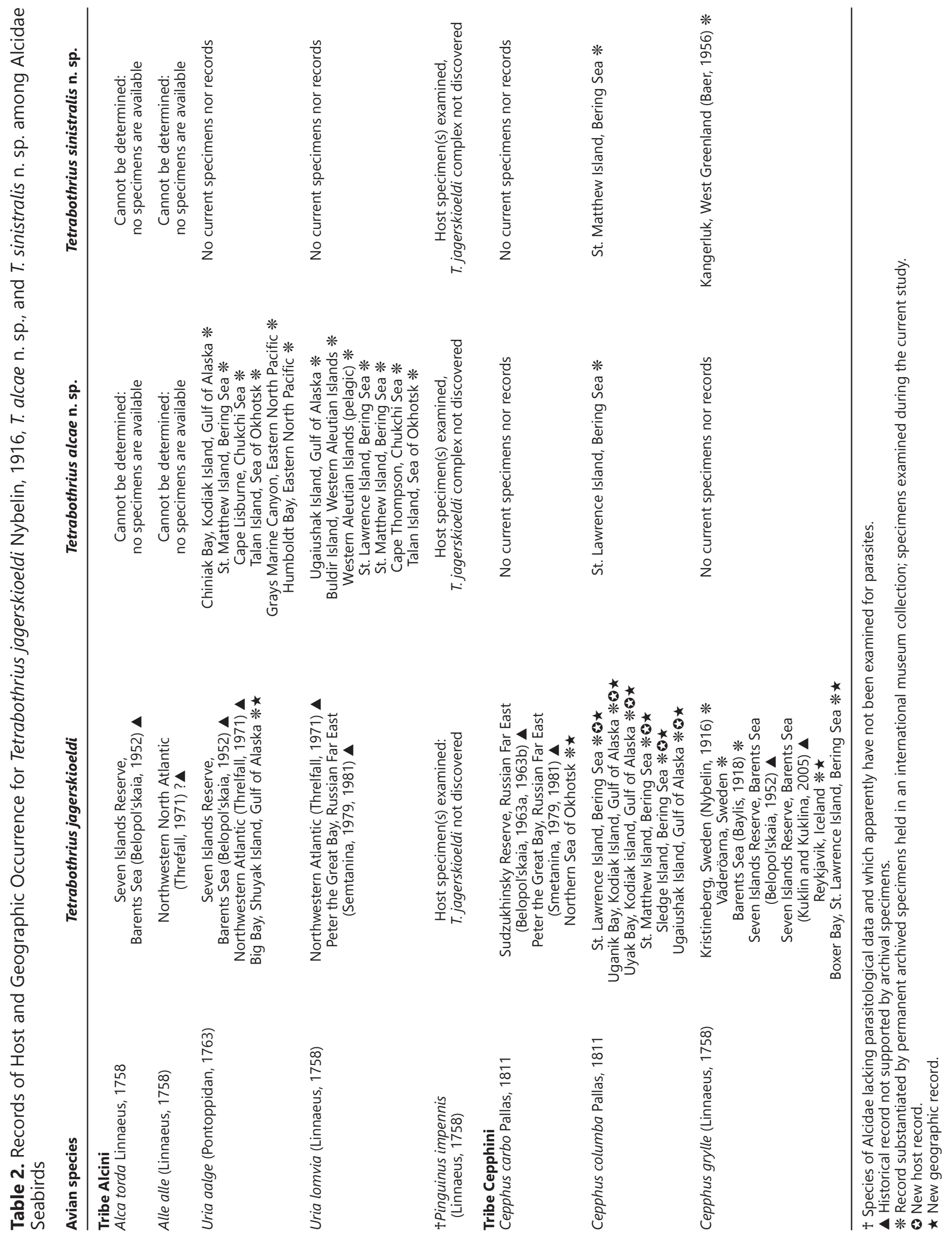




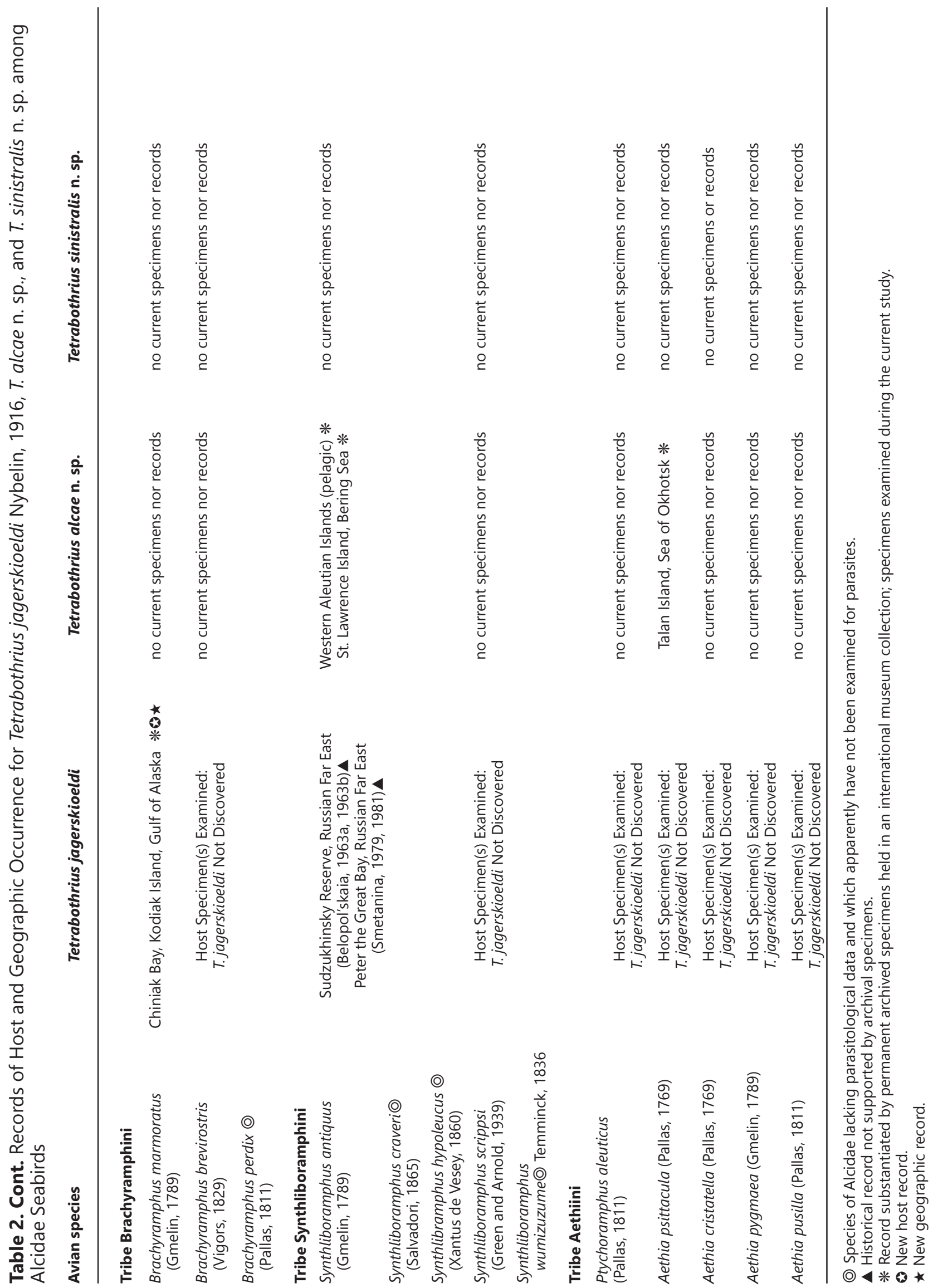




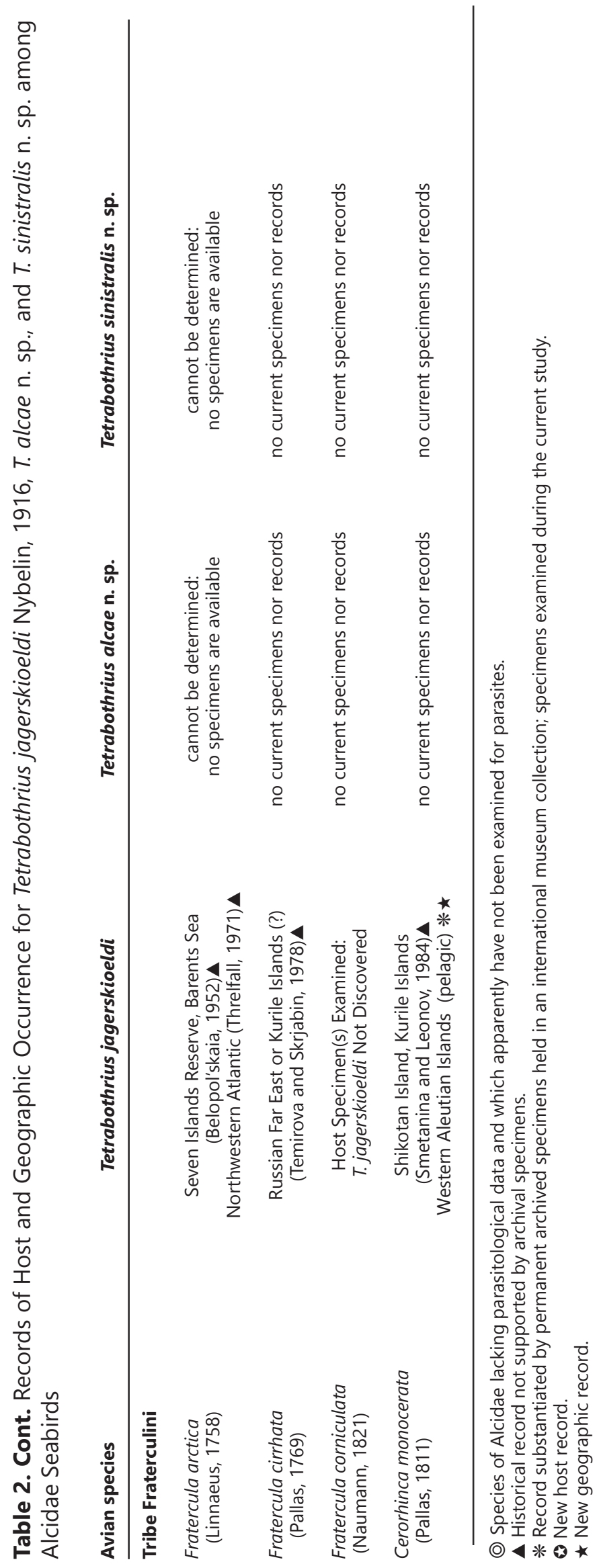




\section{Discussion}

We begin the resolution of the T.jagerskioeldi-species complex with descriptions of Tetrabothrius alcae $\mathrm{n}$. sp. based on numerous specimens from the greater North Pacific basin and Tetrabothrius sinistralis n. sp. based on cestodes from the central Bering Sea and West Greenland. These species of Tetrabothrius are the first to be described in avian hosts since the late 1980s, indicating the degree to which attention to these dominant marine cestodes has languished. It remains apparent that extensive revision of this group is required, including redescription and validation of the now 52 nominal species in avian and mammalian hosts (e.g., Hoberg, 1987b, 1994, 1996; Mariaux et al., 2017). A principal tenet continues for complete descriptions and redescriptions that adopt a standardized basis for morphological and mensural comparisons reflecting progressive modification of the genital organs during ontogeny (e.g., Rawson, 1964; Murav'eva and Popov, 1976; Hoberg, 1987b; Hoberg et al., 1991). When possible, integrated approaches that embody molecular and genomics data with comparative morphology should be expected, although such will not be a generality in assessing diversity assembled through centuries of collections and with the relatively minimal numbers of specimens now held in museum repositories globally. New and continuing field collections with accumulation of archived specimens, biodiversity information, and robust phylogenetic assessments will be central to resolution of diversity and history for tetrabothriids, species of Tetrabothrius, and related genera among the more than 326 species of seabirds (excluding Anseriformes), 91 Cetartiodactyla (suborders Odontoceti and Mysticeti), and 36 Pinnipedia (e.g., Hoberg 1996; Hoberg et al., 2013; Dunnum et al., 2017; Mariaux et al., 2017). Following descriptions of Tetrabothrius alcae and Tetrabothrius sinistralis, the genus Tetrabothrius contains 44 species that are parasites in marine avian hosts with 3 nominal cestode taxa among Alcidae.

\section{Fallacy of Expected Identification}

The history of this apparent complex has been confused. Historically, identifications of T. jagerskioeldi were based on host association (host identity = parasite identity) directly linked to expectations emerging from cospeciation and assumed specificity (e.g., Nylin et al., 2018; Brooks et al., 2019). Knowledge or assumptions about diversity were derived from a host-centric view and host taxonomy rather than from parasite morphology, genetic data, and phylogeny, a generality which has been apparent across diverse assemblages of hosts and parasites. Parasite taxonomy as a reflection or extension of host range has historically been a core assumption of parasite biodiversity knowledge. A context linking cospeciation, host specificity, species limits, and taxonomy has been effectively refuted with the advent of phylogenetic/comparative methods (e.g., Hoberg and Brooks, 2008 and references therein; Agosta et al., 2010; Brooks et al., 2019). A context for seabird parasite diversity, and especially published records among the Alcidae, has been strongly influenced by these assumptions over the past century following the description of T. jagerskioeldi by Nybelin (Nybelin, 1916).

Superficial resemblance of large tetrabothriid cestodes has been problematic. Thus, any large tetrabothriid in an alcid host would by default be identified as T. jagerskioeldi. As we noted, the understanding of the distribution of parasite diversity among alcids and other seabirds has been confounded by the nearly universal absence of a large series of archival vouchers in museum collections (Hoberg and Soudachanh, 2020). Although we refer to this broadening assemblage recognized as a species-complex, that idea currently rests on overall morphological similarity in the absence of a phylogenetic foundation. It will remain to be revealed the degree to which these species of large Tetrabothrius among the Alcidae are related as a series of sister species representing a clade within a broader phylogenetic framework that comprises cestodes among the Aequornithae (core water birds-Gaviiformes, Procellariiformes + Sphenisciformes, Suliformes [Phalacrocoracidae, Sulidae, Fregatidae, Anhingidae] + Pelecaniformes [Pelecanidae and others]), Phaethontiformes, Podicipediformes, and other Charadriiformes, in addition to cetaceans and pinnipeds (e.g., Hoberg, 1996; see Jarvis et al. [2014] for entry to current higher avian phylogeny and taxonomy).

\section{A Complex of Tetrabothrius Species among Alcidae}

Specimens of $T$. alcae were discovered predominantly in common and thick-billed murres across a broad distribution encompassing 11 localities from the greater northern North Pacific, Bering Sea, Chukchi Sea, and northern Sea of Okhotsk (Table 2; Supplementary Data Table 3; Supplementary Data Table 4). Cestodes attributed to this species were rarely observed in other species of alcids and included specimens archived from 2 ancient murrelets, a pigeon guillemot, and a parakeet auklet (Supplementary Data Table 3, Supplementary Data Table 4). Tetrabothrius alcae is currently unrecognized in the Arctic basin and North Atlantic, although it is likely to have been confused with T. jagerskioeldi in prior inventories (e.g., Hoberg and Soudachanh, 2020).

A direct consequence of misidentification is revealed in errors that have emerged in redescriptions and the perpetuation of those conclusions in the literature that influence assumptions about host range (e.g., Baer, 1954; 
Temirova and Skrjabin, 1978; Ryzhikov et al., 1985; Muzzafar and Jones, 2004). Specifically, specimen(s) in Stercorarius parasiticus (Linnaeus, 1758) from Chukotka, Cepphus carbo from the Russian Far East, and Fratercula arctica (Linnaeus, 1758) from the Barents Sea appear to have contributed to a composite redescription of $T$. jagerskioeldi that likely includes the former taxon, T. alcae and another currently undescribed species (see Temirova and Skrjabin, 1978; Hoberg and Soudachanh, 2020). Our contention that the redescription of Temirova and Skrjabin (1978) represents a species chimaera is based on morphological incompatibility (as depicted in the figures from Temirova and Skrjabin) relative to the original type series of $T$. jagerskioeldi and other validated specimens from the North Pacific (discussed in Hoberg and Soudachanh, 2020). Resolving sources for these specimens is also complicated. Specimens in parasitic jaeger appear to be from Chukotka (village of Enurmino, Chukotka Autonomous Okrug, Russia, ca. 66 $56^{\prime} 44.80^{\prime \prime} \mathrm{N}$,

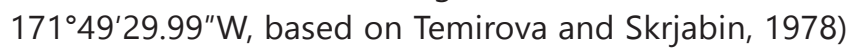
rather than Seven Islands, East Murman (as suggested in Hoberg and Soudachanh, 2020), and the original collector is undetermined. Cestodes in C. carbo, presumably from the Okhotsk or adjacent seas, are likely attributable to Belopol'skaia (1963a, 1963b), whereas those in Atlantic puffin from the Barents Sea were from earlier collections (Belopol'skaia, 1952).

Absence of archival vouchers, misattribution, and inattentive identification with subsequent uncritical duplication of published records serve to confound our perspective for host and geographic range (e.g., Muzzafar and Jones, 2004). Prior collections attributed to T. jagerskioeldi in Cepphus grylle, Alca torda, Uria aalge; Fratercula arctica; and Stercorarius parasiticus from the Seven Islands, Gosudarstvennogo Zapovednik in the Barents Sea, were unaccompanied by morphological descriptions, and any vouchers were later destroyed accidentally (Belopol'skaia, 1952).

Reports of $T$. jagerskioeldi in species of murres ( $U$. aalge and U. lomvia) appear likely to represent $T$. alcae (e.g., Threlfall, 1971; Belopol'skaia, 1952). Substantiated records of $T$. jagerskioeldi indicate a Holarctic oceanic distribution principally among 3 species of Cepphus guillemots across a minimum of 15 insular localities based on recognized specimens (Nybelin, 1916; Baylis, 1919; Hoberg and Soudachanh, 2020). Archival specimens, aside from those among the Cepphini are limited to a single cestode in U. aalge at Shuyak Island (Gulf of Alaska), 9 cestodes in B. marmoratus at Kodiak Island (Gulf of Alaska), and one in $\mathrm{C}$. monocerata from pelagic waters south of the western Aleutian Islands (Table 2; Supplementary Data Table 3). Beyond the Alcidae, in the North Pacific basin T. jagerskioeldi is known from a single specimen in Urile pelagicus (Pallas, 1811) (at Buldir Island) and from multiple specimens in Larus glaucescens Naumann, 1840 (at Puffin Island and Central Island in the Gulf of Alaska) (Hoberg and Soudachanh, 2020).

A paucity of archived voucher specimens from prior field collections that reported T. jagerskioeldi among murres, guillemots, other alcids, and marine charadriiforms from the North Pacific, Arctic, and North Atlantic hinders direct attribution of species identity within the complex (e.g., Belopol'skaia, 1952, 1963a, 1963b; Baer, 1956; Threlfall, 1971; Smetanina, 1979, 1981; Temirova and Skrjabin, 1978; Kuklin and Kuklina, 2005). It seems remarkable that T. alcae, T. sinistralis, and a cryptic complex had remained unrecognized for the past century, given that these species are unequivocally differentiated by multiple suites of unique structural attributes relative to T. jagerskioeldi (Table 1) (Hoberg and Soudachanh, 2020). It is apparent that $T$. alcae, T. jagerskioeldi, and T. sinistralis may occur in sympatry but with minimal overlap in the faunas associated with murres (Alcini) and guillemots (Cepphini) (Table 2; Supplementary Data Table 3). Current records for $T$. sinistralis are insufficient to document the actual limits for host and geographic distribution, although this species minimally occurs across the Holarctic with specimens in C. grylle from Greenland and C. columba from the Bering Sea (Table 2).

\section{Defining Diversity among Tetrabothriids}

Complex historical, biological, and physical oceanographic drivers provide explanations of diversity and faunal assembly in tetrabothriid faunas (Hoberg, 1995; Hoberg and Adams, 2000; Hoberg and Brooks, 2008). Deep phylogenetic inference within the Eucestoda, relative to the Cyclophyllidea, indicates considerable age, duration, persistence, and extensive diversification for this fauna among marine birds attributable to episodes of host colonization (Hoberg et al., 1997; Hoberg, Gardner, et al., 1999; Hoberg, Jones, et al., 1999; Hoberg et al., 2001; Caira et al., 2014). Further, episodes of colonization in conjunction with cophylogenetic processes (where cophylogeny is not a synonym for cospeciation-see Brooks et al., 2019), may also determine the foundations of faunal structure for species of Tetrabothrius among orders, families, and subfamilies of core water birds (Hoberg, 1989, 1996). The extent and chronology of switching events within cophylogenetic histories of association among genera and species occurring in seabirds, pinnipeds, and cetaceans have yet to be completely elucidated, although colonization appears to be a major component of diversification (Hoberg, 1995; Hoberg, Gardner, et al., 1999; Hoberg and Brooks, 2008; Araujo et al., 2015; Brooks et al., 2019). 
Circulation of species of Tetrabothrius among alcids (and a larger assemblage of parasites and marine homeotherms) depends on capacity for infection by cestodes and host foraging behaviors and conditions influenced by foodwebs and prey availability that determine opportunity spatially and temporally. Ecological partitions emerging in fitness space can influence host range and are evident across spatial and temporal scales. Ecological interactions directly and indirectly influence connectivity within foodwebs and are seen in (1) aspects of foraging behavior and capacity (distance, depth, time); (2) taxonomic prey spectrum (e.g., adult and larval fishes, macro- and microzooplankton, cephalopods, and other invertebrates); (3) prey selection, size, and availability (diel and vertical spatial patterns); and (4) physical oceanographic conditions (water mass structure, zonation, temperature, nearshore and offshore upwelling, advection and current regimes, frontal zones and eddies in relation to islands, and marine stratification and sea ice, especially in the Sea of Okhotsk and Bering Sea) (e.g., Ainley, Strong, et al., 1990; Springer et al., 1999; Piatt and Springer, 2003; Sydeman et al., 2017; Hunt et al., 2018; Piatt et al., 2018, 2020). Regional and seasonal dynamics are at play with shifts by foraging seabirds among and between diverse prey resources over space and time (Ainley, Strong, et al., 1990; Hunt et al., 2018; Kitasky and Hunt, 2018). Ocean-atmosphere interactions, including the shifting thermal regimes of the El Niño Southern Oscillation and the Pacific Decadal Oscillation, further influence marine productivity, temporal and spatial restructuring of foodwebs, and the potential for continuity in life history and life cycles for assemblages of marine parasites (e.g., Chavez et al., 2003; Anderson and Piatt, 1999; Hoberg, 1996, 2005; Mouritsen and Poulin, 2002; Sydeman et al., 2012, 2015; Hoberg et al., 2017). Persistent high-temperature anomalies, or marine heat waves, emerging from global warming are shifting the overall structure and phenology of foodwebs (Schultz et al., 2009; Piatt et al., 2020; Suryan et al., 2021). Changing trajectories, which are now being recognized across the greater North Pacific ecosystem under climate forcing, may constitute physical and biological tipping points (e.g., Lenton et al., 2008, 2019; Brovkin et al., 2021) and are resulting in large-scale mortality events for seabirds and marine mammals (e.g., Jones et al., 2018, 2019; Piatt et al., 2020). These factors of marine biological structure, diversity, and conditions within foodwebs are predicted to either facilitate or dampen transmission dynamics and occurrence of marine parasites, driving previously unrecognized associations and distributions among invertebrate, piscine, and avian hosts (e.g., Hoberg, 1996, 2005; Hoberg et al., 2017; Hoberg and Soudachanh, 2020).
The dynamics of prey resources exploited by seabirds vary biogeographically (Piatt et al., 2018). Availability and prey selection by diverse assemblages of resident breeding and migratory seabirds will be strongly influenced by marine province or domain. Seabirds rely on a broad assemblage of potential prey species but generally exploit a narrow array of piscine and invertebrate species spatially and oceanographically and relative to the breeding cycle (e.g., Ainley and Sanger, 1979). Seasonally the greater North Pacific is not homogeneous; consequently, conditions in the subarctic pelagic domain will be different relative to the Sea of Okhotsk, the Aleutian Arc, islands of the Bering Sea and Chukchi Sea, Gulf of Alaska, and province of the California Current (e.g., Ainley and Sanger, 1979; Hunt, Burgeson, et al., 1981; Hunt et al., 2018; Ogi, 1982; Springer et al., 1999; Piatt and Springer, 2003; Paredes et al., 2012; Piatt et al., 2018). For example, in the upwelling system of the Farallones (California Current), breeding alcids and migrating sooty shearwaters are dependent on what has been termed the "juvenile rockfish economy," which can drive extensive overlaps in foraging and diets (Ainley, Strong, et al., 1990). In contrast, in systems strongly influenced by advection in the Bering Sea, Aleutian Islands, and northern Gulf of Alaska, distinctly different assemblages of pelagic fishes, zooplankton, and cephalopods are critical resources (e.g., Ainley and Sanger, 1979; Hunt, Burgeson, et al., 1981; Schneider and Hunt, 1982; Springer et al., 1999; Piatt and Springer, 2003; Sydeman et al., 2017).

Diverse potential prey resources across space and time lead us to ask about the common elements of these systems that may contribute to continuity of life cycles for a multispecies complex of Tetrabothrius tapeworms on broad oceanographic scales. How do these relationships change across oceanographic provinces and in a regime of warming and extreme events (e.g., Hunt et al., 2018; Sydeman et al., 2017; Kitaysky and Hunt, 2018; Piatt et al., 2020)? This is the interface, viewed through a Darwinian lens, for the nature of the organism and the nature of the conditions that interact in processes of faunal assembly over time (e.g., Brooks et al., 2019; Agosta and Brooks, 2020). Fundamental fitness space- the potential for these cestodes to utilize resources across diverse marine avian species-appears broad, whereas realized fitness space and the actual array of host species that are accessed may be restricted or facilitated at any point in time. These complex relationships in sloppy fitness space that link parasites, invertebrate and piscine intermediate (and paratenic) hosts, and seabirds are reflected through realized host range, an outcome of ecological fitting and oscillation in any particular slice of ecological time (e.g., Agosta et al., 2010; Hoberg et al., 2017; Brooks et al., 2019). 


\section{Alcid Tetrabothrius Are Rare}

Alcids and cestodes of the T. jagerskioeldi-complex are restricted to cold marine systems of advection and upwelling along coastal margins adjacent to the continental shelf or are associated with archipelagos (especially the Aleutians), isolated islands, and rocky headlands of the Bering Sea, Chukchi Sea, Gulf of Alaska, Sea of Okhotsk, and Sea of Japan. Especially important is the eastern boundary current (with an upstream connection to the cold Kurishio Current and the West Wind Drift south of the Aleutians) that extends along the narrow continental shelf on the western coast of North America (Ainley, 1990). As a zone of spectacular marine productivity, these marine provinces support great diversity and populations of breeding alcids, larids, phalacrocoracids, and some procellariids and hydrobatids, while serving as seasonal migration corridors for procellariiforms and other seabirds (Hunt, Burgeson, et al., 1981; Hunt, Eppley, et al., 1981; Hunt, Gould, et al., 1981; Ainley, 1990; Piatt and Springer, 2003). Amphi-Pacific distributions among Alcidae, bounded by cold water systems from the Sea of Japan to the southern reaches of the northeastern Pacific along the California Current (and the seas of the Arctic basin into the North Atlantic), constitute the smallest (most restricted) oceanic range of any seabird group. Transmission for cestodes and persistence of this fauna is expected to be associated with pelagic and neritic systems adjacent to colony sites in zones where critical prey species are concentrated or secondarily dispersed downstream by predictable advective processes and become available to foraging birds (e.g., Hoberg, 1995, 1996, 2005). Life cycles are completed across the extent of the oceanographic distribution for Alcidae and this assemblage of Tetrabothrius. Focal zones or metaphorical islands of transmission (concentrating prey, infected intermediate hosts, and seabirds) are indicated by recency of infections and cestodes with scolexes and strobila in early stages of ontogeny collected from multiple hosts, host species, and age classes associated with colony sites spanning the greater North Pacific basin, Bering Sea, and Chukchi Sea (Figs. 50-61; Supplementary Data Table 3; Supplementary Data Table 4). Focality in transmission is consistent with birds returning to predictable regions where foraging has been successful on varying temporal/ spatial scales in the context of frontal zones, upwelling, ice edges, and prey aggregations, such as spawning shoals of fishes, zooplankton, or cephalopods (Woo et al., 2008; Elliot et al., 2009; Paredes et al., 2012; Harding et al., 2013; Hunt et al., 2018).

Our inventory indicates that these cestodes occur infrequently when assessed across all species of alcids examined; for T. alcae (53 of 1,345 alcids, 4\%), T. sinistralis (1 of $1,345,<1.0 \%$ ), and T. jagerskioeldi (14 of $1,345, \sim 1.0 \%$ ). This obscures the occurrence (and greater prevalence) of respective cestode species within a limited spectrum of hosts, or within particular age classes of a host species (e.g., murres and T. alcae; guillemots and T. jagerskioeldi) as outlined previously. Among these species of the complex, only T. jagerskioeldi has been shown unequivocally (based on validated specimens) to infect avian hosts in other families, including a larid and a phalacrocoracid (Hoberg and Soudachanh, 2020). Absolute (or realized) host range (here the number of species infected) is similar for T. alcae ( 5 species of alcids; most prevalent among 2 species of Uria, overall, $11.5 \%$ ) and T. jagerskioeldi ( 6 alcids; most prevalent among 3 species of Cepphus, overall, 32\%; also in single species of Urile Bonaparte, 1855 (see also Phalacrocorax Brisson, 1760 and Sticticarbo Bonaparte, 1856) and Larus Linnaeus, 1758 , although the spectrum of host diversity differs (Table 2). These patterns of occurrence parallel the distribution of large Tetrabothrius spp. (reported as T. jagerskioeldi) among adults of other alcid host species and across oceanographically widespread localities spanning Holarctic seas, where prevalence rarely exceeds $10 \%$ and infections are of low intensity (only exceptionally $>1-2$ cestodes in individual hosts) (e.g., Belopol'skaia, 1952; Threlfall, 1971; Smetanina, 1979, 1981).

Recognition of a cryptic complex emphasizes the rarity of broad host range for any species in this assemblage. Cestode species appear limited to particular subfamilies and tribes within the Alcidae in an arena defined by the dimensions of opportunity (e.g., Alcinae-including Alcini [T. alcae] and Cepphini [T. jagerskioeldi and T. sinistralis (?)] or Fraterculinae-including Fraterculini and Aethiini [Tetrabothrius n. sp., undescribed]). These patterns are also consistent with the distribution and occurrence for species of Alcataenia Spasskaia, 1971 (distantly related cyclophyllidean tapeworms in alcids and larids) among murres and a broader assemblage of sympatric alcids in the Holarctic (e.g., Hoberg, 1984, 1992b). For example, as we have noted, $T$. jagerskioeldi occurs primarily among 3 species of guillemots while having a capacity to infect other alcids and nearshore or shelf-edge seabirds minimally, including marble murrelets, rhinoceros auklets, common murres, a larid, and a phalacrocoracid. Likewise, T. alcae occurs primarily among 2 species of murres with a capacity to infect a broader assemblage of alcids (e.g., parakeet auklets, ancient murrelets, and pigeon guillemots) based on opportunity.

These patterns demonstrate that host range and transmission among these cestodes is defined by opportunity. Differences in prevalence for $T$. alcae between common and thick-billed murres were not apparent, suggesting ecologically equivalent (but not identical) sources and pathways 
for transmission over wide expanses of the North Pacific basin. Variation in exploitation of piscine versus benthic invertebrates as prey does not appear to influence prevalence (see Swartz, 1967; Piatt and Springer, 2003). Essentially, these observations may serve to eliminate amphipods or euphausiids from consideration as intermediate hosts for T. alcae. Euphausiids, and particularly species of Thysanoessa Brandt, 1851 are recognized intermediate hosts for other cestodes among alcids (species of Alcataenia), suggesting these pelagic crustaceans may not be involved in life cycles and transmission among species of Tetrabothrius (e.g., Hoberg, 1984, 1996). Differences in prevalence for Alcataenia tapeworms in murres were attributed to prey selection and greater importance of euphausiids in diets of thick-billed murres in contrast to common murres from the central Bering Sea.

Murres are the dominant avian marine piscivores of the North Pacific, foraging near the continental margins across oceanic (pelagic) environments and over the continental shelf adjacent to colony sites (e.g., Piatt and Springer, 2003; Iverson et al., 2007; Piatt et al., 2018; Piatt et al., 2020). Thick-billed murres exploit pelagic fishes over shelf habitats and a wide diversity of oceanic prey, including euphausiids, amphipods, and squid (Ainley and Sanger, 1979). Common murres forage almost exclusively on pelagic schooling fish during the summer. Murres explore and exploit a greater range of habitats over wider areas and distances compared to guillemots, emphasizing a dependence on mid-depth fishes and midwater schooling prey (e.g., Ainley, Strong, et al., 1990; Boekelheide et al., 1990; Elliot et al., 2009; Piatt and Springer, 2003; Piatt et al., 2020).

Where data are available-for example, for T. alcae and murres-young birds (near the time of fledging) and subadults ( $35 \%$ prevalence) are consistently infected with greater frequency than adult breeding birds (7\%) (Supplementary Data Table 3). Differences in prevalence between adult birds and young prior to fledging may be expected as a generality (although data are elusive) and are consistent with field observations, indicating selective presentation of energetically valuable piscine prey to developing chicks by breeding birds (e.g., Tuck and Squires, 1955; Spring, 1968). In the high Arctic, adult thickbilled murres may forage on amphipods during incubation and then shift to high-energy fishes during chick rearing (Woo et al., 2008; Elliott et al., 2009). Similar disparities in prevalence between fledgling birds and adults for other species of Tetrabothrius among larid hosts [Rissa tridactyla (Linnaeus), Larus schistisagus Stejneger] have also been documented and are considered indicators of differential prey selection (or presentation) of fishes or zooplankton relative to host age (Hoberg, 1992a, 1996).
Guillemots demonstrate less variable foraging ranges in contrast to murres. Benthic-littoral fishes and shoals or aggregations of pelagic fishes are exploited through foraging in shallow nearshore and intertidal environments (e.g., Ainley and Sanger, 1979; Ainley, Boekelheide, et al., 1990; Litzow et al., 2004). Considerable selectivity may result in a narrow prey base at some sites and over periods of time (Ainley, Boekelheide, et al., 1990). Although data are minimal, such selectivity appears to extend across the chickrearing period, and infections recognized for T. jagerskioeldi may be more prevalent in young birds versus breeding adults (see Belopol'skaia [1952] for large Tetrabothrius in black guillemots). Further, outcomes of prey selection may be compounded by dissimilarities in zooplankton exploited by pelagic and or demersal forage fishes, and variation in these trophic links, relative to avian hosts, could influence potential transmission pathways for cestodes and other parasites. Relative ecological isolation among murres, guillemots, and their respective prey assemblages, or factors that determine opportunity through foodwebs and spatial distribution, may have explanatory power for understanding the host ranges for T. alcae and T. jagerskioeldi, with parasites secondarily revealing insights about the structure of the North Pacific marine ecosystem.

\section{Tetrabothrius in the North Pacific System}

Abundance for species of Tetrabothrius among alcid hosts is low, prevalence is limited, and cestodes were not demonstrated at all oceanic or geographic sites where intensive sampling was conducted (Supplementary Data Table 2; Supplementary Data Table 3). Sampling error and uneven collections across localities could influence these observations. It is apparent, however, that annual to decadal variation may occur in the diversity and distribution of large Tetrabothrius tapeworms among alcids across and within oceanographic provinces (e.g., Hoberg et al., 2013; compare Threlfall [1971] and Muzzafar [2009] for marine systems from the eastern Canadian Arctic to west Greenland; see Belopol'skaia [1952], Galaktionov [1995], and Kuklin and Kuklina [2005] for Barents Sea and East Murman). Fundamentally, this reflects temporal disparities in physical and biological oceanographic determinants for marine productivity, prey spectrum, and availability on regional, provincial, and local scales over time (e.g., Ainley, 1990; Ainley, Strong, et al., 1990; Anderson and Piatt, 1999; Sydeman et al., 2017; Piatt et al., 2018; Hunt et al., 2018). Consequently, the diets of seabirds (at least during breeding cycles) depend on the oceanographic location of a colony site in a physically and biologically heterogeneous ocean (Schneider and Hunt, 1982) which secondarily defines a window of time in which parasite transmission is occurring (e.g., Hoberg, 1996, 2005). 
Table 3. Specimens and Localities for Procellariiformes Infected with Species of Tetrabothrius from the Greater North Pacific during the Boreal Summer

Species/Localities ${ }^{1,2}$

Number of Hosts ${ }^{3}$

Ardenna creatopus (Coues, 1864) / Pink-footed Shearwater

Grays Marine Canyon, Washington State, Eastern North Pacific / 8 September 1982

Grays Marine Canyon, Washington State, Eastern North Pacific / 31 August 1985

Grays Marine Canyon, Washington State, Eastern North Pacific / 21 August 1987

Ardenna bulleri (Salvin, 1888) / Buller's Shearwater

Grays Marine Canyon, Washington State, Eastern North Pacific / 31 August 1985

Ardenna tenuirostris (Temminck, 1836) / Short-tailed Shearwater

Central Bering Sea and Bristol Bay, Bering Sea, Alaska

$\left(56^{\circ} 37^{\prime} \mathrm{N}, 170^{\circ} 26^{\prime} \mathrm{W}\right.$ to $\left.56^{\circ} 55^{\prime} \mathrm{N}, 159^{\circ} 49^{\prime} \mathrm{W}\right) /$ August-September 1976

Kodiak Island region, Gulf of Alaska / June-September 1977

Western Aleutians, Pelagic / 1981

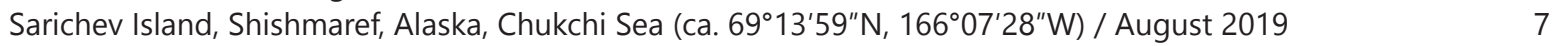

Ardenna grisea (Gmelin, 1789) / Sooty Shearwater

Kodiak Island region, Gulf of Alaska / June-September 1977

Western Aleutians, Pelagic / 1981

Grays Marine Canyon, Washington State, Eastern North Pacific / 31 August 1985

Grays Marine Canyon, Washington State, Eastern North Pacific/ 21 August 1987

Fulmarus glacialis (Linnaeus, 1761) / Northern Fulmar

Bristol Bay, Alaska, Bering Sea / May 1970

Nunivak Island, Alaska, Bering Sea / 30 August 1949

Central Bering Sea and Bristol Bay, Bering Sea, Alaska

$\left(56^{\circ} 37^{\prime} \mathrm{N}, 170^{\circ} 26^{\prime} \mathrm{W}\right.$ to $\left.56^{\circ} 55^{\prime} \mathrm{N}, 159^{\circ} 49^{\prime} \mathrm{W}\right)$ / August-September 1976

Western Aleutians, Pelagic / 1981

Grays Marine Canyon, Washington State, Eastern North Pacific / 31 August 1985

Grays Marine Canyon, Washington State, Eastern North Pacific / 21 August 1987

4

7

Oceanodroma furcata (Gmelin, 1789) / Fork-tailed Storm Petrel

Western Aleutians, Pelagic / 1981

Western Aleutians, Pelagic, south of Tanaga and Adak Island / 1982

Grays Marine Canyon, Washington State, Eastern North Pacific / 8 September 1982

Phoebastria nigripes (Audubon, 1839) / Black-footed Albatross

Grays Marine Canyon, Washington State, Eastern North Pacific / 8 September 1982

1

Grays Marine Canyon, Washington State, Eastern North Pacific / 21 August 1987

Specimens Examined $=103$

Species Examined $=7$

\section{Notes:}

${ }^{1}$ Localities correspond to those outlined in Supplementary Data Tables 2 and 3, except Sarichev Island, Shismaref, Alaska, in 2019, which is noted in the current table.

${ }^{2}$ Host voucher specimens from Grays Marine Canyon are held in the Burke Memorial Washington State Museum.

3Prevalence for species of Tetrabothrius cannot be accurately determined for all host species and localities based on these collections. Prevalence approached $100 \%$ in most species and localities, and specimen numbers above reflect all procellariiforms in which Tetrabothrius was found or collected. 
We can provisionally begin to explore the limits on host and spatial range with explanations about rarity, low abundance, and insular occurrence within an otherwise extensive and simultaneously patchy oceanographic distribution for these species of Tetrabothrius among Alcidae. How do rare species of parasites become oceanographically widespread, as is apparent for the T. jagerskioeldi-complex in an open system defined by degrees of dilution? Resolving these contrasting observations is at the interface for physical and biological processes: (1) Are there ecologically equivalent but taxonomically diverse zooplankton, cephalopod, and piscine taxa with capacities to serve as appropriate hosts (compatibility across a host assemblage) in varying oceanographic provinces in the context of ecological fitting? In this sense, capacity is equated with compatability under the perspective of all species (intermediate and definitive) involved in an association. (2) Are there widespread but rare prey species that consistently serve as an assemblage of intermediate host(s) across oceanographic domains? (3) Does rarity reflect dilution by distance from an island focus (colony site) and as an outcome of dispersed but central-place foraging in neritic and pelagic waters (Hoberg, 1996; Elliott et al., 2009; Harding et al., 2013)? and/or (4) Are infections influenced through dilution by advection downstream that may determine the distribution of infective stages in the water column and infected intermediate hosts at increasing distances from islands and foraging zones (Hoberg, 1995)? (5) What are the parameters of passive advection and dispersal for parasites (e.g., Piatt and Springer, 2003) in contrast to connectivity mediated by highly vagile seabirds (see parallels to species of Anophryocephalus Baylis, 1922 cestodes in northern pinnipeds; Hoberg, 1995). In this context, when do intermediate and potential paratenic hosts become infected and when are these competent in transmission pathways? Completion of these marine life cycles may be influenced by the limits on foraging behavior, feeding capacity (e.g., physical limitations on particle size or prey dimensions for foraging), and food selection by zooplankters, larval and adult fishes, and cephalopods of different age and size classes and life history patterns at the interface with seabird hosts (e.g., Hoberg, 1996). These are the dimensions in sloppy fitness space for developing metacestodes and opportunity that circumscribes the potential for infections in avian hosts and which defines realized host range within the broader extent of fundamental fitness space (Brooks et al., 2019). Multiple transmission pathways, through ecological fitting, may characterize particular oceanic provinces related to distinct assemblages of invertebrate, piscine, and avian diversity (e.g., Springer et al., 1996; Piatt et al., 2018).

\section{Complexity and Considerations within a Larger Fauna}

Prevalence revealed among species of the T. jagerskioeldicomplex in alcids is considerably lower than that seen for an assemblage of Tetrabothrius among resident species of Laridae and resident and migratory species of Procellariiformes, which may occur in sympatry (e.g., Hoberg, 1992a, 1996; Hoberg and Soudachanh, 2020; Supplementary Data Table 3; Table 3). No matter the species reported-for example, most published inventory records reported as $T$. jagerskioeldi are expected to be largely incorrect-prevalence of large Tetrabothrius is largely consistent with a picture of infrequent occurrence in Holarctic alcids. Concurrently, species typical of a Tetrabothrius fauna among Holarctic Laridae (e.g., T. erostris and T. cylindraceus) are rarely observed among alcids (Hoberg and Soudachanh, 2020); other high-latitude species such as T. morschtini have not been recognized in alcids (Murav'eva, 1968; Temirova and Skrjabin, 1978; Galkin, 1994; Hoberg and Soudachanh, 2020). Additionally, species reported in the literature in alcid hosts, including T. macrocephalus, have not been directly confirmed based on archived specimens.

Faunas are ecologically segregated and appear spatially structured between nearshore and pelagic environments; substantial differences in diversity, abundance, and prevalence of infection are apparent. For example, large larid gulls (species of Larus), with eclectic foraging in neritic and littoral waters and relative proximity to intertidal systems, generally support assemblages of high prevalence (often near 100\%) and intensity of infection for multiple species of Tetrabothrius, in addition to helminth faunas of great diversity (e.g., Belogurov, 1966; Belogurov et al., 1968; Hoberg, 1992a, 1996, 2005). A departure from this spatial/ecological relationship for helminth diversity in larids is demonstrated among kittiwakes, Rissa tridactyla, which forage in pelagic environments and support considerably lower species diversity and prevalence of infection for helminths (summarized in part by Hoberg, 1992a, 2005; Hoberg and Soudachanh, 2020; Supplementary Data Table 3). Patterns of pelagic foraging among these disparate groups of seabirds may explain diversity, relative to nearshore environments, although prevalence and abundance of cestodes among procellariiform hosts appears to be an exception.

Cestodes of the T. jagerskioeldi-complex, based on current collections, are absent among resident and transient procellariform seabirds in the North Pacific basin during the boreal summer (Supplementary Data Table 3). Species of shearwaters including sooty [Ardenna grisea (Gmelin, 1789)], short-tailed [A. tenuirostris (Temminck, 1836)], and pink-footed [A. creatopus (Coues, 1864)] are oceanographically wide-ranging seabirds that breed deep in the southern hemisphere during the austral summer. Subsequently, 
following dispersal from colony sites and northward (transequatorial) migration from the southern oceans, shearwaters become a dominant component of the avifauna on neritic and pelagic waters of the subarctic North Pacific and Bering Sea during the boreal summer (Hunt, Gould, et al., 1981; Ogi, 1982). Distributions for a larger assemblage of resident procellariiforms - for example, northern fulmars [Fulmarus glacialis (Linnaeus, 1761)], fork-tailed [Oceanodroma furcata (Gmelin, 1789)] and Leach's [O. leucorhoa Vieillot, 1818] storm petrels, black-footed [Phoebastria nigripes (Audubon, 1939)] and Laysan [P. immutablis (Rothschild, 1893)] albatrosses—alcids, larids, and stercorariids, are regionally to locally abundant, becoming sympatric with these species of Ardenna seasonally and during migration (e.g., Hunt, Gould, et al., 1981; Chu, 1982; Ogi, 1982).

In the North Pacific and Bering Sea, high prevalence, approaching $100 \%$, with intensity of infection often exceeding 100-200 cestodes in individual hosts, characterized multiple species of Tetrabothrius in a diverse assemblage, but relatively limited sample, of pelagic foraging shearwaters and other procellariiforms (Table 3; E.P. Hoberg, unpublished data). These distributions are in contrast to the rarity of cestodes attributed to the T. jagerskioeldi-complex in alcids (Supplementary Data Table 3); respective cestode faunas remain strongly segregated. Although requiring complete evaluation, species in this tetrabothriid fauna among shearwaters appear distinct from those circulating respectively among alcids and larids and other seabirds that occur in sympatry during the boreal spring, summer, and autumn (E.P. Hoberg, unpublished data).

Faunas explored in great shearwaters [A. gravis ( $\mathrm{O}$ 'Reilly, 1818)] from the Atlantic basin serve to emphasize the minimal overlap in cestode species that circulate in the northern and southern hemispheres among migratory and resident procellariiforms (Hoberg and Ryan, 1989). Cestode diversity is represented by different species assemblages in the southern and northern hemispheres with transmission circumscribed by breeding cycles associated with isolated colony sites. Among great shearwaters, the major component of cestode diversity was derived from the South Atlantic Ocean adjacent to breeding grounds (on Gough Island) during the austral spring and summer: $100 \%$ prevalence with maximum intensity of infection exceeding 4,000 cestodes in individual hosts. Transequatorial migration from the south brings different assemblages into sympatry, although contact among avian hosts in common foraging zones does not apparently result in colonization by parasites; for example, no species or other elements of these faunas are shared among procellarifiorms, larids, and alcids. Inventory data suggested a sequential loss of some elements of this fauna in shearwaters, without replace- ment, during northward migration and during a period of residency in the North Atlantic (Hoberg and Ryan, 1989; Hoberg, 1996). Despite common trophic resources seasonally exploited by shearwaters, alcids, and larids across the greater North Pacific, these cestode faunas may circulate through ecologically segregated pathways with minimal exchange (Ainley and Sanger, 1979; Ogi, 1982; Chu et al., 1982). Collectively, these observations are consistent with the considerable abundance of tetrabothriid cestodes in pelagic foraging procellariform seabirds. Concurrently, strong ecological and historical segregation among major groups of marine birds may limit or facilitate opportunity that partitions parasite diversity on regional or provincial scales (see also Hoberg, 1995; Hoberg and Adams, 2000).

Narrow host range with minimal overlap for elements of this fauna are consistent with outcomes of episodes of oceanographic expansion (exploration and host colonization) alternating with bouts of isolation in refugial zones (exploitation and coadaptation) through the late Tertiary period (e.g., Hoberg, 1992b; Hoberg et al., 2012, 2017). Faunal dynamics can be explained within the context of the Stockholm paradigm (e.g., Hoberg and Brooks, 2008; Araujo et al., 2015; Brooks et al., 2019; Agosta and Brooks, 2020). Faunal assembly represents the outcomes of oscillating climate, shifting ranges (breakdown in isolation, ecological fitting, and exploration modes for cestodes), and the changing interfaces for resource availability maintained by trophic and habitat overlaps. Dynamics of these ecotones constitute the nexus of opportunity and capacity for infection among avian hosts in which capacity appears broad and opportunity is ecologically restricted in space and time. Multiple life history pathways are tied to trophic associations and dynamics at mesoscales across marine domains and provinces (consider Gulf of Alaska, Bering and Chukchi Sea, high-latitude gyre systems) (Springer et al., 1996, 1999; Piatt et al., 2018). Resilience and connectivity through ecological fitting strongly suggest the influence of multiple trophic pathways for transmission and persistence (including a history of diversification) of this complex fauna (differing assemblages of zooplankters, fishes, and cephalopods depending on locality, oceanographic conditions, and temporal variability) (e.g., Sydeman et al., 2017; Piatt et al., 2018, 2020).

Returning to the T. jagerskioeldi-complex, transmission occurs across the extent of the greater Pacific basin (Sea of Okhotsk, Bering Sea, Chukchi Sea, Aleutian Arc, Gulf of Alaska, and California Current systems). These are oceanographically definable domains or provinces (characterized by water mass, advection, and upwelling) with distinct but ecologically equivalent assemblages of zooplankton, cephalopods, and fishes. Provincial-level foodwebs are the foundations for prey selection and resource use by particular 
seabirds (e.g., Ainley and Sanger, 1979; Piatt and Springer, 2003; Sydeman et al., 2017; Piatt et al., 2018). Relatively few prey elements are in common or occur consistently across all marine domains. There is broad capacity, however, for completion of life cycles for cestodes across all domains, with transmission circumscribed by breeding cycles and oceanographic location of colonies. These observations are compatible with transmission being limited by opportunity, in the context of partitions in the distribution of tapeworms among particular marine birds (e.g., murres and guillemots), which are to a degree ecologically segregated. Persistence for species of Tetrabothrius is driven by a particular host genus, with broad fundamental fitness space (capacity) indicated by sporadic infection in other alcids in sympatry. These interactions describe the relationship of fundamental fitness space (and potential host range), realized fitness space and outcomes for ecological fitting in sloppy fitness space in faunal assembly, and diversification over time as predicted under the Stockholm paradigm (Agosta et al., 2010; Brooks et al., 2019; Agosta and Brooks, 2020).

Alcid tapeworms circulate under the dynamics of capacity (potential observed for broad multispecies host assemblages) with limits imposed by ecological opportunity. Changing conditions, especially ecological perturbations driven by climate oscillations, directly determine production cycles and distributions of micro- and macro-zooplankton, forage fishes, cephalopods, and trophic structure in highlatitude marine ecosystems. Ocean-atmosphere oscillations-or regime shifts from cold to warm cycles, such as the El Niño Southern Oscillation, Pacific Decadal Oscillation, and the North Atlantic Oscillation-drive one scale of episodic ecological reorganization that will influence foodwebs and the potential for persistence and transmission of marine parasites (e.g., Piatt et al., 1998; Anderson and Piatt, 1999; Hurrell et al., 2003; Chavez et al., 2003; Sydeman et al., 2012; Hoberg et al., 2017; Hoberg and Soudachanh, 2020). Climate and ocean warming can drive the potential for local to regional shifts in the host and geographic distribution of this parasite fauna (e.g., Hoberg and Soudachanh, 2020).

Environmental perturbation is a driver of faunal change, in part reflected in persistence through origins of new host and geographic associations, or under catastrophic disruption a context for extirpations and extinctions (Hoberg and Brooks, 2008; Stigall et al., 2017; Brooks et al., 2019; Agosta and Brooks, 2020). Changing conditions that alter opportunity space may lead to broadening of host range, such that when the original host(s) become extinct, the parasite(s) will survive, a principal demonstrated across evolutionary and ecological time in persistence of complex parasite-host assemblages through ecological fitting and colonization (e.g., Hoberg and Brooks, 2008; Brooks et al., 2019). As a generality, species that persist through major episodes of environmental disruption are those that can leave their original habitats and survive elsewhere based on conserved capacities under a regime of new opportunity (Stigall, 2010, 2012; Stigall et al., 2017; Agosta and Brooks, 2020). In the context of perturbations in the North Pacific ecosystem, such alterations that result in a significant loss of avian species diversity, coincident with a broader reorganization of ecological structure, could produce a small number of surviving avian hosts that support a diverse assemblage of parasites that were not each other's closest relatives, although they might be "related." Under cophylogenetic assumptions, these findings would be consistently misinterpreted as "cophylogeny = cryptic cospeciation" and therefore massive coextinction (Brooks et al., 2019). Consequently, temporal and spatial faunal baselines explored in a backdrop derived from phylogeny can reveal trajectories and new patterns of faunal assembly over time and provide direct insights about systems under dynamic change (e.g., Brooks et al., 2014).

During the past two to three decades, anthropogenic forcing and extensive climate-driven shifts in ecosystem structure have emerged across the greater North Pacific and the provinces of the California Current, Aleutian Arc, Gulf of Alaska, and Bering Sea. Widespread failures of forage fish and high-energy zooplankton, with direct consequences for persistence and reproductive success for marine birds, have been a general outcome for restructuring of nektonic communities (e.g., Schultz et al., 2009; Piatt et al., 2020; Suryan et al., 2021). Persistent high-temperature anomalies, as exemplified by the extreme marine heatwave that unfolded over the years 2014-16, are transforming the entire structure of high-latitude foodwebs, leading to shifts in latitudinal composition and abundance of zooplankton, fishes, and cephalopods, which may reflect cascading physical and biological tipping points (e.g., Jones et al., 2019; Piatt et al., 2020; Suryan et al., 2021; Brovkin et al., 2021). Cascades unfolding from an acceleration in climate forcing and oscillation in marine habitats, with shifting thermal balances and resulting environmental sloshing, are analogous to processes observed in terrestrial systems (Kafle et al., 2020). These expanding regimes of accelerating change emphasize the critical importance of field collections, archives, and baselines to assess biological outcomes across temporal and spatial scales (e.g., Hoberg et al., 2013; Brooks et al., 2014; Dunnum et al., 2017; Cook et al., 2017). Parasite assemblages reveal macro- to meso-scale connectivity serving as adjuncts and proxies in recognizing and understanding outcomes for episodes of environmental oscillation and directional atmospheric and oceanic warming 
in marine ecosystems (e.g., Hoberg, 1996; Springer et al., 1996, 2007; Hoberg et al., 2013; Hoberg et al., 2017; Piatt et al., 2018; Hoberg and Soudachanh, 2020).

Acknowledgments - Joseph and Nella Cook, Felipe Cook, Solé, Remy, Kitty, and the Cook Estancia in the shadow of Sandia Mountain have contributed immeasurably to completion of our explorations of Tetrabothrius diversity. Continued explorations of evolutionary and ecological dynamics under the Stockholm paradigm with Daniel Brooks, Walter Boeger, and Salvatore Agosta are appreciated. The Museum of Southwestern Biology (MSB), Parasitology Division, University of New Mexico, and collections manager Sara Brant curated, archived, and databased our specimens in the Arctos platform and provided laboratory facilities, instrumentation, and general support. Specimens from field collections spanning the decades in Alaskan marine waters were provided by Robert and Virginia Rausch (including specimens from Everett L. Schiller and Francis H. "Bud" Fay) through the R. L. and V. R. Rausch Helminthological Collections at the MSB. Helminthological specimens collected during Project Chariot $(1959,1960)$ from the Cape Thompson region by L. Gerard "Jerry" Swartz were made available for evaluation. Successive curators, Claude Vaucher and Jean Mariaux, Museum d' Histoire Naturelle, Geneva, provided specimens collected by Jean G. Baer from West Greenland in the 1950s. Original field collections spanned the North Pacific basin, extending into the Arctic: the US Geological Survey (under the former US Fish and Wildlife Service, USFWS) supported fieldwork during the Aleutian Canada Goose Recovery Program on Buldir Island and Amchitka Island $(1975,1976)$ with G. Vernon Byrd, John Trapp, Duff H. S. Wehle, and Robert Day. The USFWS supported studies of seabird parasite diversity on Ugaiushak Island (1976) and Kodiak Island (1977) during the Outer Continental Shelf Environmental Assessment Program with Duff $\mathrm{H}$. S. Wehle, David Nysewander, Patricia Baird, Alan Moe, and Doug Forsell. Fieldwork with David Roseneau, Max Hoberg, and Margaret Dykes-Hoberg on St. Matthew Island (1982) was conducted in conjunction with USFWS. Pelagic collections off the continental shelf of Washington State (1982, $1985,1987)$ were organized by Sievert Rohwer and staff of the Burke Memorial Washington State Museum, University of Washington, Seattle, and supported in part by Garett Eddy and assisted by Keith Aubry, Carol Spaa, Dennis Paulson, and others. Diversity assessments and collections were centered at Chaun Biological Station in the Russian Arctic (1981) with Svetlana Bondarenko, Vitus Kontrimavichus, Gennady Atrashkevich, Alexander Kondratiev, and Luba Kondratieva and at Talan Island (1988) with A. Kondratiev, L. Kondratieva, Alexander Kitaysky, Alexi Pinchuck, and S.
Bondarenko under interacademy exchanges between the National Academy of Sciences (USA) and Russian Academy of Sciences with support from the Institute for Biological Problems of the North, Magadan. Diversity assessments were also facilitated by specimens provided through a considerable network of field biologists, including Richard Fitzner (Destruction Island and Protection Island, Washington, 1981); Charles Drost (Channel Islands, California, 1987, 1988); Mark Phillips (Humboldt Bay, California, 1977, 1979); Patrick Gearin (western Aleutians, 1981, 1982), Douglas Causey (western Aleutians, 1991, 1992, 2002); Jane Homan (Point Barrow, Alaska, and St. Paul Island, 1979); and Jean Bédard, John Piatt, Alan Springer, and David Roseneau (St. Lawrence Island). Cestodes in avian specimens collected adjacent to Sarichev Island, Shishmaref, Alaska, by USFWS personnel during a marine mortality event for shearwaters and other seabirds in the Chukchi Sea in 2019 were provided by Gary E. Shugart from the Slater Museum, University of Puget Sound. Our current study benefited our continuing discussions with Kirill Galaktionov about faunal diversity and historical biogeography in northern marine ecosystems. Lastly, Lori Hawkins provided technical assistance in the preparation of our manuscript.

\section{Literature Cited}

Agosta, S.J.; Brooks, D.R. 2020. The Major Metaphors of Evolution: Darwinism Then and Now. Springer International Publishing, Cham, Switzerland. 273 pp. https://doi. org/10.1007/978-3-030-52086-1

Agosta, S.J.; Janz, N.; Brooks, D.R. 2010. How specialists can be generalists: Resolving the "parasite paradox" and implications for emerging infectious disease. Zoologia (Curitiba) 27: 151-162. https://doi.org/10.1590/ $\underline{\mathrm{S} 1984-46702010000200001}$

Ainley, D.G. 1990. Seasonal and annual patterns in the marine environment near the Farallones. In: Seabirds of the Farallon Islands: Ecology, Dynamics, and Structure of an Upwelling-System Community. D.G. Ainley, R.J. Boekelheide (eds.). Stanford University Press, Stanford, CA. 23-50 p.

Ainley, D.G.; Boekelheide, R.J.; Morell, S.H.; Strong, C.S. 1990. Pigeon guillemot. In: Seabirds of the Farallon Islands: Ecology, Dynamics, and Structure of an UpwellingSystem Community. D.G. Ainley, R.J. Boekelheide (eds.). Stanford University Press, Stanford, CA. 276-305 p.

Ainley, D.G.; Sanger, G.A. 1979. Trophic relations of seabirds in the Northeastern Pacific Ocean and Bering Sea. In: Conservation of Marine Birds of Northern North America. J. Bartonek, D.N. Nettleship (eds.). US Department of the Interior. Wildlife Research Report 11. Washington, DC. 95-122 p. 
Ainley, D.G.; Strong, C.S.; Penniman, T.M.; Boekelheide, R.J. 1990. The feeding ecology of Farallon seabirds. In: Seabirds of the Farallon Islands: Ecology, Dynamics, and Structure of an Upwelling-System Community. D.G. Ainley, R.J. Boekelheide (eds.). Stanford University Press, Stanford, CA. 51-127 p.

Anderson, P.J.; Piatt, J.F. 1999. Community reorganization in the Gulf of Alaska following ocean climate regime shift. Marine Ecology Progress Series 189: 117-123.

Araujo, S.B.L.; Braga, M.P.; Brooks, D.R.; Agosta, S.; Hoberg, E.P.; von Hathental, F.; Boeger, W.A. 2015. Understanding host-switching by ecological fitting. PLOS ONE 10(10): e0139225. https://doi.org/10.1371/journal. pone.0139225

Baer, J.G. 1954. Revision Taxonomique et Étude Biologique des Cestodes de la Famille Tetrabothriidae: Parasites d'Oiseaux de Haute Mer et de Mammifères Marins. Mémoires de I'Université de Neuchâtel. Série in-quarto tome 1. $121 \mathrm{pp}$.

Baer, J.G. 1956. Parasitic helminths collected in West Greenland. Meddelelser om Grønland 124(10): 5-55.

Baylis, H.A. 1919. A collection of Entozoa chiefly from birds from the Murman coast. Annals and Magazine of Natural History, Series 9, 3: 501-514.

Belogurov, O.I. 1966. Spetsifichnost' gel'mintov v otnoshenii definitivnykh khoziawev vzaimosviaz' gel'mintofauna zhivotnykh razlichykh otriadov (po materialam s okhotskogo poberezh'ia). Zoolgicheskie Zhurnal 45: 1449-1454.

Belogurov, O.I.; Leonov, V.A.; Zueza, L.S. 1968. Gel'mintofauna ryboiadnykh ptits (chaek i chistikov) poberezh'ia okhotskogo moria. Gel'minty Zhivotnykh Tikhogo Okeana. Akad Nauk SSSR, Moskva. pp. 105-124.

Belopol'skaia, M.M. 1952. Parazitofauna morskikh vodoplavaiushchikh ptits. Lenigradskogo Universitet Uchenye Zapiski. Seria Biologicheskikh Nauk 141: 129-180.

Belopol'skaia, M.M. 1963a. Obzor parazitofauny ptits Sudzukhinskogo Zapovednika (Primor'e). Parazit Sbornik 21: 221-224.

Belopol'skaia, M.M. 1963b. Parazitofauna ptits Sudzukhinskogo Zapovednika (Primor'e) IV. Lentochnye chervii (Cestoidea). Trudy Gel'mintologicheskii Laboratoriia 13: 144-163.

Boekelheide, R.J.; Ainley, D.G.; Morrell, S.H.; Huber, H.R.; Lewis, T.J. 1990. Common murre. In: Seabirds of the Farallon Islands: Ecology, Dynamics, and Structure of an Upwelling-System Community. D.G. Ainley, R.J. Boekelheide (eds.). Stanford University Press, Stanford, CA. 243-275 p.

Brooks, D.R.; Hoberg, E.P.; Boeger, W.A. 2019. The Stockholm Paradigm: Climate Change and Emerging Disease. University of Chicago Press, Chicago. 423 pp.

Brooks, D.R.; Hoberg, E.P.; Gardner, S.L.; Boeger, W.; Galbreath, K.E.; Herczeg, D.; Mejía-Madrid, H.H.; Racz, E.; Tsogtsaikhan Dursahinhan, A. 2014. Finding them before they find us: informatics, parasites and environments in accelerating climate change. Comparative Parasitology 81: 155-164.

Brovkin, V.; Brook, E.; Williams, J.W.; Bathiany, S.; Lenton, T.M.; Barton, M.; DeConto, R.M.; Donges, J.F.; Ganopolski, A.; Mcmanus, J.; Praetorius, S.; de Vernal, A.; Abe-Ouchi, A.; Cheng, H.; Claussen, M.; Crucifix, M.; Gallopín, G.; Iglesias, V.; Kaufman, D.S.; Kleinen, T.; Lambert, F.; van der Leeuw, S.; Liddy, H.; Loutre, M.-F.; McGee, D.; Rehfeld, K.; Rhodes, R.; Seddon, A.W.R.; Trauth, M.H.; Vanderveken, L.; Yu, Z. 2021. Past abrupt changes, tipping points and cascading impacts in the Earth system. Nature Geoscience 14: 550-558. https://doi.org/10.1038/ s41561-021-00790-5

Caira, J.N.; Jensen, K.; Waeschenbach, A.; Olson, P.D.; Littlewood, D.T.J. 2014. Orders out of chaos-molecular phylogenetics reveals the complexity of shark and stingray tapeworm relationships. International Journal for Parasitology 44: 55-73.

Chavez, F.P.; Ryan, J.; Lluch-Cota, S.E.; Ñiquen, C.M. 2003. From anchovies to sardines and back: multidecadal change in the Pacific Ocean. Science 299: 217-221.

Chesser, R.T.; Billerman, S.M.; Burns, K.J.; Cicero, C.; Dunn, J.L.; Kratter, A.W.; Lovette, I.J.; Mason, N.A.; Rasmussen, P.C.; Remsen, J.V., Jr.; Stotz, D.F.; Winker, K. 2020. Checklist of North and Middle American Birds (online). American Ornithological Society. http://checklist.americanornithology.org/taxa/

Chu, E.W. 1982. Sooty shearwaters off California: diet and energy gain. In: Marine Birds: Their Feeding Ecology and Commercial Fisheries Relationships. D.N. Nettlership, G.A. Sanger, P.F. Springer (eds.). Special Publication, Canadian Wildlife Service, Ottawa. 64-71 p.

Cook, J.A.; Galbreath, K.E.; Bell, K.C.; Campbell, M.L.; Carrière, S.; Colella, J.P.; Dawson, N.G.; Dunnum, J.L.; Eckerlin, R.P.; Federov, V.; Greiman, S.E.; Hass, G.M.S.; Haukisalmi, V.; Henttonen, H.; Hope, A.G.; Jackson, D.; Jung, T.S.; Koehler, A.V.; Kinsella, J.M.; Krejsa, D.; Kutz, S.J.; Liphardt, S.; MacDonald, S.O.; Malaney, J.L.; Makarikov, A.; Martin, J.; Mclean, B.S.; Mulders, R.; Nyamsuren, B.; Talbot, S.L.; Tkach, V.V.; Tsvetkova, A.; Toman, H.M.; Waltari, E.C.; Whitman, J.S.; Hoberg, E.P. 2017. The Beringian Coevolution Project: holistic collections of mammals and associated parasites reveal novel perspectives on evolutionary and environmental change in the North. Arctic Science 3: 585-617. https://doi. org/10.1139/as-2016-0042

Dunnum, J.L.; Yanagihara, R.; Johnson, K.M.; Armien, B.; Batsaikhan, N.; Morgan, L.; Cook, J.A. 2017. Biospecimen repositories and integrated databases as critical infrastructure for pathogen discovery and pathobiology research. PLOS Neglected Tropical Diseases, 11: e0005133. https://doi.org/10.1371/journal.pntd.0005133

Elliott, K.H.; Woo, K.J.; Gaston, A.J.; Benvenuti, S.; Dall'Antonia, L.; Davoren, G.K. 2009. Central-place foraging in an Arctic seabird provides evidence for Storer-Ashmole's halo. Auk 126: 613-625. 
Galaktionov, K.V. 1995. Long-term changes in the helminth fauna of colonial seabirds in the Seven Islands archipelago (Barents Sea, Eastern Murman). In: Ecology of Fjords and Coastal Waters. H.R. Skjolda, C. Hopkins, K.E. Erikstad, H.P. Leinaas (eds.). Elsevier Science, Amsterdam. 489-496 p.

Galkin, A.K. 1987. O stanovlenii netsiklofillidnykh tsestod parazitov chaek. Trudy Zoologicheskogo Instituta, Akademiya Nauk SSSR 161: 3-23.

Galkin, A.K.; Galaktionov, K.V.; Marasaev, S.F.; Prokof'ev, V.V. 1994. Tsestody ryboiadnykh ptits O. Kharlov i Zemli Frantsa-luosifa. Parazitologiia 28: 373-383.

Harding, A.; Paredes, R.; Suryan, R.; Roby, D.; Irons, D.; Orben, R.; Renner, H.; Young, R.; Barger, C.; Dorresteijn, I.; Kitaysky, A. 2013. Does location realty matter? An inter-colony comparison of seabirds breeding at varying distances from productive oceanographic features in the Bering Sea. Deep-Sea Research II 94: 178-191.

Harris, M.P.; Birkhead, T.R. 1985. Breeding ecology of the Atlantic Alcidae. In: The Atlantic Alcidae. D.N. Nettleship, T.R. Birkhead (eds.). Academic Press, Orlando, FL. 155-204 p.

Harris, M.P.; Wanless, S.; Barton, T.R.; Elston, D.A. 1997. Nest site characteristics, duration of use, and breeding success in the guillemot Uria aalge. Ibis 139: 468-476. https://onlinelibrary.wiley.com/doi/abs/10.1111/j.1474919X.1997.tb04660.x

Hoberg, E.P. 1984. Alcataenia longicervica sp. n. from murres, Uria lomvia (Linnaeus) and Uria aalge (Pontoppidan) in the North Pacific basin, with redescriptions of Alcataenia armillaris (Rudolphi, 1810) and A. meinertzhageni (Baer, 1956) (Cestoda: Dilepididae). Canadian Journal of Zoology 62: 2044-2052.

Hoberg, E.P. 1987a. Recognition of larvae of the Tetrabothriidae: implications for the origin of tapeworms in marine homeotherms. Canadian Journal of Zoology 65: 997-1000.

Hoberg, E.P. 1987b. Tetrabothrius shinni sp. n. (Eucestoda), from Phalacrocorax atriceps bransfieldensis (Pelecaniformes) in Antarctica, with comments on morphological variation and host-parasite biogeography and evolution. Canadian Journal of Zoology 65: 2969-2975.

Hoberg, E.P. 1989. Phylogenetic relationships among genera of the Tetrabothriidae (Eucestoda). Journal of Parasitology 75: 617-626.

Hoberg, E.P. 1992a. Ekologiia gel'mintov morskikh ptits ostrova Talan (predvaritel'ny obzor). [Ecology of helminth parasitism among seabirds at Talan Island, USSR, a preliminary overview.] In: Prebrezhnye Ekosistemy Severnogo Okhotomor'ia Ostrov Talan. [Coastal Ecosystems in the Northern Part of the Sea of Okhotsk.] F.B. Tschernyavsky, A. la. Kondratiev (eds.). Institute for Biological Problems of the North, Far Eastern Branch, Russian Academy of Sciences, Magadan, Russia. 116$136 \mathrm{p}$.
Hoberg, E.P. 1992b. Congruent and synchronic patterns in biogeography and speciation among seabirds, pinnipeds and cestodes. Von Ihering Centenary Symposium in Biogeography and Coevolution. Journal of Parasitology 78: 601-615.

Hoberg, E.P. 1994. Order Tetrabothriidea. In: CIP Keys to the Cestode Parasites of Vertebrates. L.F. Kahlil, A. Jones, R. Bray (eds.). CAB International Institute of Parasitology and British Museum (Natural History). 295-304 p.

Hoberg, E.P. 1995. Historical biogeography and modes of speciation across high latitude seas of the Holarctic: concepts for host-parasite coevolution among the Phocini (Phocidae) and Tetrabothriidae (Eucestoda). Canadian Journal of Zoology 73: 45-57.

Hoberg, E.P. 1996. Faunal diversity among avian parasite assemblages: the interaction of history, ecology and biogeography. Bulletin of the Scandinavian Society of Parasitology 6: 65-89.

Hoberg, E.P. 2005. Marine birds and their helminth parasites. In: Marine Parasitology (chapter 10, Economic, environmental and medical importance). K. Rohde (ed.). CSIRO, Sydney, Australia. 414-421 p.

Hoberg, E.P.; Adams, A.M. 2000. Phylogeny, history and biodiversity: understanding faunal structure and biogeography in the marine realm. Bulletin of the Scandinavian Society of Parasitology 10: 19-37.

Hoberg, E.P.; Adams, A.M.; Rausch, R.L. 1991. Revision of the genus Anophryocephalus Baylis, 1922 from pinnipeds in the Holarctic with descriptions of Anophryocephalus nunivakensis sp. n. and $A$. eumetopii sp. n. (Tetrabothriidae) and evaluation of host records from the Phocidae. Canadian Journal of Zoology 69: 1653-1668.

Hoberg, E.P.; Brooks, D.R. 2008. A macroevolutionary mosaic: episodic host-switching, geographic colonization, and diversification in complex host-parasite systems. Journal of Biogeography 35: 1533-1550.

Hoberg, E.P.; Cook, J.A.; Agosta, S.J.; Boeger, W.; Galbreath, K.E.; Laaksonen, S.; Kutz, S.J.; Brooks, D.R. 2017. Arctic systems in the Quaternary: ecological collision, faunal mosaics and the consequences of wobbling climate. Journal of Helminthology 91: 409-421. https://doi. org/10.1017/S0022149X17000347

Hoberg, E.P.; Galbreath, K.E.; Cook, J.A.; Kutz, S.J.; Polley, L. 2012. Northern host-parasite assemblages: history and biogeography on the borderlands of episodic climate and environmental transition. In: Advances in Parasitology, volume 79. D. Rollinson, S.I. Hays (eds.). Elsevier, Amsterdam. 1-97 p.

Hoberg, E.P.; Gardner, S.L.; Campbell, R.A. 1999. Systematics of the Eucestoda: advances toward a new phylogenetic paradigm, and observations on the early diversification of tapeworms and vertebrates. Systematic Parasitology 42: 1-12.

Hoberg, E.P.; Jones, A.; Bray, R. 1999. Phylogenetic analysis among families of the Cyclophyllidea (Eucestoda) based 
on comparative morphology, with new hypotheses for coevolution in vertebrates. Systematic Parasitology 42: 51-73.

Hoberg, E.P.; Kutz, S.J.; Cook, J.A.; Galaktionov, K.; Haukisalmi, V.; Henttonen, H.; Laaksonen, S.; Makarikov, A.; Marcogliese, D.J. 2013. Parasites in terrestrial, freshwater and marine systems. In: Arctic Biodiversity Assessment: Status and Trends in Arctic Biodiversity. H. Meltofte (ed.). Conservation of Arctic Flora and Fauna, Arctic Council, Akureyi, Iceland. 476-505 p.

Hoberg, E.P.; Mariaux, J.; Brooks, D.R. 2001. Phylogeny among orders of the Eucestoda (Cercomeromorphae): integrating morphology, molecules and total evidence. In: Interrelationships of the Platyhelminthes. D.T.J. Littlewood, R.A. Bray (eds.). Taylor and Francis, London. 112-126 p.

Hoberg, E.P.; Mariaux, J.; Justine, J.-L.; Brooks, D.R.; Weekes, P.J. 1997. Phylogeny of the orders of the Eucestoda (Cercomeromorphae) based on comparative morphology: historical perspectives and a new working hypothesis. Journal of Parasitology 83: 1128-1147.

Hoberg, E.P.; Measures, L.N. 1995. Anophryocephalus inuitorum sp. nov. and $A$. arcticensis sp. nov. (Eucestoda: Tetrabothriidae) in ringed seals (Phoca hispida hispida) and harp seals (Phoca groenlandica) from high-latitude seas of eastern Canada and the Arctic basin. Canadian Journal of Zoology 73: 34-44.

Hoberg, E.P.; Ryan, P.G. 1989. Ecology of helminth parasitism in Puffinus gravis (Procellariiformes) on the breeding grounds at Gough Island. Canadian Journal of Zoology 67: 220-225.

Hoberg, E.P.; Soudachanh, K.M. 2020. Insights about diversity of Tetrabothriidae (Eucestoda) among Holarctic Alcidae (Charadriiformes): What is Tetrabothrius jagerskioeldi? Manter: Journal of Parasite Biodiversity. Occasional Papers, Number 11: 1-42. https://doi.org/10.32873/unl. dc.manter11

Hunt, G.L.; Burgeson B.; Sanger, G.A. 1981. Feeding ecology of seabirds of the Eastern Bering Sea. In: The Eastern Bering Sea Shelf: Oceanography and Resources. Vol. 2. D. W. Hood, J.A. Calder (eds.). University of Washington Press, Seattle. 629-647 p.

Hunt, G.L.; Eppley, Z.; Drury, W.H. 1981. Breeding distribution and reproductive biology of marine birds in the Eastern Bering Sea. In: The Eastern Bering Sea Shelf: Oceanography and Resources. Vol. 2. D.W. Hood, J.A. Calder (eds.). University of Washington Press, Seattle. 649-687.

Hunt, G.L.; Gould P.J.; Forsell, D.J.; Peterson, H., Jr. 1981. Pelagic distribution of marine birds in the Eastern Bering Sea. In: The Eastern Bering Sea Shelf: Oceanography and Resources. Vol. 2. D.W. Hood, J.A. Calder (eds.). University of Washington Press, Seattle. 689-718 p.

Hunt, G.L.; Renner, M.; Kuletz, K.J.; Salo, S.; Eisner, L.; Ressier, P.H.; Ladd, C.D.; Santora, J.A. 2018. Timing of sea-ice retreat affects the distribution of seabirds and their prey in the southeastern Bering Sea. Marine Ecology Progress Series 593: 209-230. https://doi.org/10.3354/ $\underline{\text { meps } 12383}$
Hurrell, J.W.; Kushnir, Y.; Otterson, G.; Visbeck, M. 2003. An overview of the North Atlantic Oscillation. Geophysical Monographs 134: 1-35.

Iverson, S.J.; Springer, A.M.; Kitaysky, A.S. 2007. Seabirds as indicators of food web structure and ecosystem variability: qualitative and quantitative diet analyses using fatty acids. Marine Ecology Progress Series 352: 235-244.

Jarvis, E.D.; Mirarab, S.; Aberer, A.J.; Li, B.; Houde, P.; Li, C.; Ho, S.Y.W.; Faircloth, B.C.; Nabholz, B.; Howard, J.T.; Suh, A.; Weber, C.C.; da Fonseca, R.R.; Li, J.; Zhang, F.; Li, H.; Zhou, L.; Narula, N.; Liu, L.; Ganapathy, G.; Boussau, B.; Bayzid, M.D.S.; Zavidovych, V.; Subramanian, S.; Gabaldón, T.; Capella-Gutiérrez, S.; Huerta-Cepas, J.; Rekepalli, B.; Munch, K.; Schierup, M.; Lindow, B.; Warren, W.C.; Ray, D.; Green, R.E.; Bruford, M.W.; Zhan, X.; Dixon, A.; Li, S.; Li, N.; Huang, Y.; Derryberry, E.P.; Bertelsen, M.F.; Sheldon, F.H.; Brumfield, R.T.; Mello, C.V.; Lovell, P.V.; Wirthlin, M.; Schneider, M.P.C.; Prosdocimi, F.; Samaniego, J.A.; Velazquez, A.M.V.; Alfaro-Núñez, A.; Campos, P.F.; Petersen, B.; Sicheritz-Ponten, T.; Pas, A.; Bailey, T.; Scofield, P.; Bunce, M.; Lambert, D.M.; Zhou, Q.; Perelman, P.; Driskell, A.C.; Shapiro, B.; Xiong, Z.; Zeng, Y.; Liu, S.; Li, Z.; Li, Z.; Liu, B.; Wu, K.; Xiao, J.; Yinqi, X.; Zheng, Q.; Zhang, Y.; Yang, H.; Wang, J.; Smeds, L.; Rheindt, F.E.; Braun, M.; Fjeldsa, J.; Orlando, L.; Barker, F.K.; Jønsson, K.A.; Johnson, W.; Koepfli, K.-P.; O'Brien, S.; Haussler, D.; Ryder, O.A.; Rahbek, C.; Willerslev, E.; Graves, G.R.; Glenn, T.C.; McCormack, J.; Burt, D.; Ellegren, H.; Alström, P.; Edwards, S.V.; Stamatakis, A.; Mindell, D.P.; Cracraft, J.; Braun, E.L.; Warnow, T.; Jun, W.; Gilbert, M.T.P.; Zhang, G. 2014. Whole-genome analyses resolve early branches in the tree of life of modern birds. Science 346: 1320-1331. https://doi.org/10.1126/ science. 1253451

Jones, T.; Divine, L.M.; Renner, H.; Knowles, S.; Lefebvre, K.A.; Burgess, H.K.; Wright, C.; Parrish, J.K. 2019. Unusual mortality of Tufted puffins (Fratercula cirrhata) in the eastern Bering Sea. PLOS ONE 14(5): e0216532. https://doi. org/10.1371/journal.pone.0216532

Jones, T.; Parrish, J.K.; Peterson, W.T.; Bjorkstedt, E.P.; Bond, N.A.; Ballance, L.T.; Bowes, V.; Hipfner, J.M.; Burgess, H.K.; Dolliver, J.E.; Lindquist, K.; Lindsey, J.; Nevins, H.M.; Robertson, R.R.; Roletto, J.; Wilson, L.; Joyce, T.; Harvey, J. 2018. Massive mortality of a planktivorous seabird in response to a marine heatwave. Geophysical Research Letters 45: 3193-3202. https://doi. org/10.1002/2017GL076164

Kafle, P.; Peller, P.; Massolo, A.; Hoberg, E.P.; Leclerc, L.-M.; Tomaselli, M.; Kutz, S. 2020. Range expansion of muskox lungworms track rapid Arctic warming: implications for geographic colonization under climate forcing. Scientific Reports 10: 17323. https://doi.org/10.1038/ s41598-020-74358-5

Kennedy, M.; Spencer, H.G. 2014. Classification of the cormorants of the world. Molecular Phylogenetics and Evolution 79: 249-257. 
Kitaysky, A.S.; Hunt, G.L., Jr. 2018. Seabird responses to a changing Bering Sea. Marine Ecology Progress Series 593: 189-194.

Kuklin, V.V.; Kuklina, M.M. 2005. Helminths of Birds of the Barents Sea: Fauna, Ecology and Influence on the Hosts. Kola Scientific Centre of the Russian Academy of Sciences Press, Apatity. [In Russian]

Lenton, T.M.; Held, H.; Kriegler, E.; Hall, J.W.; Lucht, W.; Rahmstorf, S.; Schellnhuber, H.J. 2008. Tipping elements in the Earth's climate system. Proceedings of the National Academy of Sciences 105: 1786-1793. https://doi. org/10.1073/pnas.0705414105

Lenton, T.M.; Rockström, J.; Gaffney, O.; Rahmstorf, S.; Richardson, K.; Steffen, W.; Schellnhuber, H.J. 2019. Climate tipping points - too risky to bet against. Nature 575: 592-595. https://doi.org/10.1038/d41586-019-03595-0

Linton, E. 1927. Notes on the cestode parasites of birds. Proceedings of the United States National Museum 70: 1-73.

Litzow, M.A.; Piatt, J.F.; Abookire, A.A.; Robard, M.D. 2004. Energy density and variability in abundance of pigeon guillemot prey: support for the quality-variability trade-off hypothesis. Journal of Animal Ecology 73: 1149-1156.

Mariaux, J.; Kuchta, R.; Hoberg, E.P. 2017. Tetrabothriidea Baer, 1954. In: Planetary Biodiversity Inventory (20082017): Tapeworms from Vertebrate Bowels of the Earth. J.N. Caira, K. Jensen (eds.). University of Kansas, Natural History Museum, Special Publication No. 25. Lawrence, Kansas. 357-370 p.

Mouritsen, K.M.; Poulin, R. 2002. Parasitism, climate oscillations and the structure of natural communities. Oikos 97: 462-468.

Murav'eva, S.I. 1968. New species of tetrabothriidae from the glaucous gull Tetrabothrius morschtini n. sp. Nauchnye Doklady Vysshei Shkoly Biologicheskie Nauki 11(4): 11-13.

Murav'eva, S.I.; Popov, V.N. 1976. Sistematicheskoe polozhenie i neketorye dannye ob ekologii Anophryocephalus skrjabini (Cestoda: Tetrabothriidae) parazita lastonoggikh. Zoologicheskie Zhurnal 55: 1247-1250.

Muzzafar, S.B. 2009. Helminths of murres (Alcidae: Uria spp.): markers of ecological change in the marine environment. Journal of Wildlife Diseases 45: 672-683. https:// doi.org/10.7589/0090-3558-45.3.672

Muzzafar, S.B.; Jones, I.A. 2004. Parasites and diseases of the auks (Alcidae) of the world and their ecology-a review. Marine Ornithology 32: 121-146.

Nybelin, O. 1916. Neue Tetrabothriiden aus Vogel. Zoologischen Anzeiger 47: 297-301.

Nylin, S.; Agosta, S.; Bensch, S.; Boeger, W.A.; Braga, M.P.; Brooks, D.R.; Forister, M.L.; Hambäck, P.A.; Hoberg, E.P.; Nyman, T.; Schäpers, A.; Stigall, A.L.; Wheat, C.W.; Österling, M.; Janz, N. 2018. Embracing colonizations: a new paradigm for species association dynamics. Trends in Ecology and Evolution. 2320. https://doi.org/10.1016/j. tree.2017.10.005
Ogi, H. 1982. Feeding ecology of the Sooty Shearwater in the western subarctic North Pacific Ocean. In: Marine Birds: Their Feeding Ecology and Commercial Fisheries Relationships. D.N. Nettleship, G.A. Sanger, P.F. Springer (eds.). Special Publication, Canadian Wildlife Service, Ottawa. 78-84 p.

Paredes, R.; Harding, A.M.A.; Irons, D.B.; Roby, D.D.; Suryan, R.M.; Orben, R.A.; Renner, H.; Young, R.; Kitaysky, A. 2012. Proximity to multiple foraging habitats enhances seabirds' resilience to local food shortages. Marine Ecology Progress Series 471: 253-269.

Piatt, J.F.; Arimitsu, M.L.; Sydeman, W.J.; Thompson, S.A.; Renner, H.; Zador, S.; Douglas, D.; Hatch, S.; Kettle, A.; Williams, J. 2018. Biogeography of pelagic food webs in the North Pacific. Fisheries Oceanography 27: 366-380. https://doi.org/10.1111/fog. 12258

Piatt, J.F.; Drew, G.; Van Pelt, T.; Abookire, A.; Nielsen, A.; Shuktz, M.; Kitaysky, A. 1998. Biological effects of the 1997/98 ENSO in Cook Inlet, Alaska. Sisyphus News 3: 1-3.

Piatt, J.F.; Parrish, J.K.; Renner, H.M.; Schoen, S.K.; Jones, T.T.; Arimitsu, M.L.; Kuletz, K.J.; Bodenstein, B.; García-Reyes, M.; Duerr, R.S.; Corcoran, R.M.; Kaler, R.S.A.; McChesney, G.J.; Golightly, R.T.; Coletti, H.A.; Suryan, R.M.; Burgess, H.K.; Lindsey, J.; Lindquist, K.; Warzybok, P.M.; Jahncke, J.; Roletto, J.; Sydeman, W.J. 2020. Extreme mortality and reproductive failure of common murres resulting from the northeast Pacific marine heatwave of 2014-2016. PLOS ONE 15(1): e0226087. https://doi.org/10.1371/ journal.pone.0226087

Piatt, J.F.; Springer, A.M. 2003. Advection, pelagic food webs and the biogeography of seabirds in Beringia. Marine Ornithology 31: 141-154.

Rawson, D. 1964. Sequences in the maturation of the genitalia in Tetrabothrius erostris (Loennberg, 1889) from the intestine of Larus argentatus Pontoppidan. Parasitology 54: 453-465.

Ryzhikov, K.M.; Rysavý, B.; Khokhlova, I.G.; Tolkatcheva, L.M.; Kornyushin, V.V. 1985. Helminths of Fish-Eating Birds of the Palearctic Region II. Cestoda and Acanthocephales. USSR Academy of Sciences, Helminthological Laboratory, Moscow.

Schneider, D.; Hunt, G.L. 1982. A comparison of seabird diets and foraging distribution around the Pribilof Islands, Alaska. In: Marine Birds: Their Feeding Ecology and Commercial Fisheries Relationships. D.N. Nettlership, G.A. Sanger, P.F. Springer (eds.). Special Publication, Canadian Wildlife Service, Ottawa. 86-95 p.

Schultz, M.T.; Piatt, J.F.; Harding, A.M.A.; Kettle, A.B.; Van Pelt, T.I. 2009. Timing of breeding and reproductive performance in murres and kittwakes reflect mismatched season prey dynamics. Marine Ecology Progress Series 393: 247-258.

Smetanina, Z.B. 1979. Tsestody ryboiadnykh ptits primorskogo kraia. Materialy nauchnoii konferentsii vsesoyznogo obshchestva gel'mintologov Vypusk 31. Tsestody i 
Tsestodzy. Akademii Nauk SSSR. Laboratoria Gelmintologii, Moskva: Akademii Nauk USSR. pp. 120-128.

Smetanina, Z.B. 1981. Gel'minty morskikh ryboiadnykh ptits Zaleva Petra Velikogo. Biologiia I Sistematika Gel'mintov Zhivotnykh Dal'nevo Vostoka. Akad Nauk SSSR., Dal' nevostochnyi Nauchnyi Tsentr, Vladivostok. pp. 71-81.

Spring, W.L. 1968. A comparison of functional and morphological adaptations in the common murre (Uria aalge) and thick-billed murre (Uria lomvia). PhD diss., University of Washington. $95 \mathrm{pp}$.

Springer, A.M.; Byrd, G.V.; Iverson, S.J. 2007. Hot oceanography: planktivorous seabirds reveal ecosystem responses to warming of the Bering Sea. Marine Ecology Progress Series 352: 289-297.

Springer, A.M.; Piatt, J.F.; Shuntov, V.P.; Van Vliet, G.B.; Vladimirov, V.L.; Kuzin, A.E.; Perlov, A.S. 1999. Marine birds and mammals of the Pacific Subarctic Gyres. Progress in Oceanography 43: 443-487.

Springer, A.M.; Piatt, J.F.; Van Vliet, G.B. 1996. Sea birds as proxies of marine habitats and food webs in the western Aleutian Arc. Fisheries Oceanography 5: 45-55.

Stigall, A.L. 2010. Invasive species and biodiversity crises: testing the link in the Late Devonian. PLOS ONE 5(12): e15584. https://doi.org/10.1371/journal.pone.0015584

Stigall, A.L. 2012. Speciation collapse and invasive species dynamics during the Late Devonian "Mass Extinction." Geological Society of America Today 22: 4-9.

Stigall, A.L.; Bauer, J.E.; Lam, A.R.; Adriane R.; Wright, D.F. 2017. Biotic immigration events, speciation, and the accumulation of biodiversity in the fossil record. Global and Planetary Change 148: 242-257.

Suryan, R.M.; Arimitsu, M.L.; Coletti, H.A.; Hopcroft, R.R.; Lindeberg, M.R.; Barbeaux, S.J.; Batten, S.D.; Burt, W.J.; Bishop, M.A.; Bodkin, J.L.; Brenner, R.; Campbell, R.W.; Cushing, D.A.; Danielson, S.L.; Dorn, M.W.; Drummond, B.; Esler, D.; Gelatt, T.; Hanselman, D.H.; Hatch, S.A.; Haught, S.; Holderied, K.; Iken, K.; Irons, D.B.; Kettle, A.B.; Kimmel, D.G.; Konar, B.; Kuletz, K.J.; Laurel, B.J.; Maniscalco, J.M.; Matkin, C.; McKinstry, C.A.E.; Monson,
D.H.; Moran, J.R.; Olsen, D.; Palsson, W.A.; Pegau, W.S.; Piatt, J.F.; Rogers, L.A.; Rojek, N.A.; Schaefer, A.; Spies, I.B.; Straley, J.M.; Strom, S.L.; Sweeney, K.L.; Szymkowiak, M.; Weitzman, B.P.; Yasumiishi, E.M.; Zador, S.G. 2021. Ecosystem response persists after a prolonged marine heatwave. Scientific Reports 11: 6235. https://doi. org/10.1038/s41598-021-83818-5

Swartz, L.G. 1967. Distribution and movements of birds in the Bering and Chukchi Seas. Pacific Science 21: 332-347.

Sydeman, W.J.; Piatt, J.F.; Thompson, S.A.; García-Reyes, M.; Hatch, S.A.; Arimitsu, M.L.; Slater, L.; Williams, J.C.; Rojek, N.A.; Zador, S.G.; Renner, H.M. 2017. Puffins reveal contrasting relationships between forage fish and ocean climate in the North Pacific. Fisheries Oceanography 26: 379-395.

Sydeman, W.J.; Poloczanska, E.; Reed, T.E.; Thompson, S.A. 2015. Climate change and marine vertebrates. Science 350: 772-777.

Sydeman, W.J.; Thompson, S.A.; Kitaysky, A. 2012. Sea birds and climate change: roadmap for the future. Marine Ecology Progress Series 454: 107-117.

Temirova, S.I.; Skrjabin, A.S. 1978. Tetrabotriaty i mezotsestoidaty lentochnye gel'minty ptits i mlekopitaiushchikh. Osnovy Tsestodologii 9. Akademii Nauk SSR, Moscow.

Threlfall, W. 1971. Helminth parasites of alcids in the northwestern North Atlantic. Canadian Journal of Zoology 49: 461-466.

Tuck, L.M.; Squires, H.J. 1955. Food and feeding habits of Brunnick's murre (Uria lomvia lomvia) on Akpatok Island. Journal of the Fisheries Research Board of Canada 12: 781-792.

Woo, K.J.; Elliot, K.H.; Davidson, M.; Gaston, A.J.; Davoren, G.K. 2008. Individual specialization in diet by a generalist marine predator reflects specialization in foraging behavior. Journal of Animal Ecology 77: 1082-1091.

Yamaguti, S. 1935. Studies on the helminth fauna of Japan. Part 6. Cestodes of Birds, I. Japanese Journal of Zoology 6: 183-232. 
Supplementary Data Table 1. Avian Specimens (Alcidae, Laridae, Stercorariidae, and Phalacrocoracidae) from the Greater North Pacific Basin Examined for Helminth Parasites (1949-2002)

Species

(Subfamily Alcinae)

Tribe Alcini

Alle alle (Linnaeus) (dovekie)

Uria aalge (Pontoppidan) (common murre)

Uria lomvia (Linnaeus) (thick-billed murre)

Tribe Cepphini

Cepphus carbo Pallas (spectacled guillemot)

Cepphus columba Pallas (pigeon guillemot)

Cepphus grylle (Linnaeus) (black guillemot)
Number

Charadriiformes-Alcidae:

1

276

150

4

22

8

Tribe Brachyramphini

Brachyramphus marmoratus (Gmelin) (marbled murrelet)

7

Brachyramphus brevirostris (Vigors) (Kittlitz's murrelet)

Tribe Synthliboramphini

Synthliboramphus antiquus (Gmelin) (ancient murrelet)

Synthliboramphus scrippsi (Green and Arnold) (Scripp's murrelet)

(Subfamily Fraterculinae)

Tribe Aethiini

Ptychoramphus aleuticus Brandt (Cassin's auklet) 16

Aethia psittacula (Pallas) (parakeet auklet) 56

Aethia cristatella (Pallas) (crested auklet) 190

Aethia pygmaea (Gmelin) (whiskered auklet) 18

Aethia pusilla (Pallas) (least auklet) 63

Tribe Fraterculini

Cerorhinca monocerata (Pallas) (rhinoceros auklet) 39

Fratercula cirrhata (Pallas) (tufted puffin) 286

Fratercula corniculata (Naumann) (horned puffin) 149

Rissa tridactyla (Linnaeus) (black-legged kittiwake) $\quad 211$

Rissa brevirostris (Bruch) (red-legged kittiwake) 2

Larus hyperboreous Gunnerus (glaucous gull) 13

Larus glaucescens (Naumann) (glaucous-winged gull) 67

Larus schistisagus Stejneger (slaty-backed gull) 27

Larus argentatus (Pontoppidan) (herring gull) 12

Larus heermani Cassin (Heerman's gull) 6

Sterna paradisaea Pontoppidan (Arctic tern) 39

$\begin{array}{lr}\text { Onychoprion aleutica (Baird) (Aleutian tern) } & 6\end{array}$

Xema sabini (Sabine) (Sabine's gull) 34

Charadriiformes-Stercorariidae:

Stercorarius pomarinus Temminck (pomarine jaeger) 14

Stercorarius parasiticus (Linnaeus) (parasitic jaeger) 4

Stercorarius longicaudus Vieillot (long-tailed jaeger) 19

Suliformes-Phalacrocoracidae:

Urile pelagicus (Pallas) (pelagic shag) 36

Urile "kenyoni" (Siegel-Causey) (Kenyon's shag) = U. pelagicus

Urile urile (Gmelin) (red-faced shag) 34

Specimens examined $=1,871$

Species examined $=34$ 
Supplementary Data Table 2. Field Data with Georeferences, Dates, and Collectors for Specimens of Alcidae, Some Laridae, and Other Seabirds Examined for Helminth Parasites from the Greater North Pacific Basin (1949-2002)

\section{Aleutian Islands, Alaska}

- Adak Island, Andreanof Islands, Bering Sea (ca. $51^{\circ} 53^{\prime} \mathrm{N}, 176^{\circ} 38^{\prime} \mathrm{E}$ ) May 1997 / D. Causey

- Amchitka Island, Constantine Harbor, Rat Islands, Bering Sea (ca. 59³0'N, $179^{\circ} 00^{\prime} \mathrm{E}$ ) 12 March 1952 / R.L. Rausch (locality reported by RLR as Kurilof Harbor) May 1976 / E.P. Hoberg

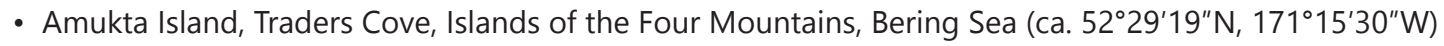
1 September 2002 / D. Causey

- Alaid Island, Semichi Islands, Bering Sea (5245'46"N, $\left.173^{\circ} 53^{\prime} 53^{\prime \prime} \mathrm{E}\right)$ August 1992 / D. Siegel-Causey

- Attu Island (Holtz Bay), Near Islands, Bering Sea (5256'50"N, 173¹1'31"E) July 1991, August 1992 / D. Siegel-Causey

- Attu Island (Etienne Bay), Near Islands, Bering Sea (5253'53"N, 172³4'56"E) August 1992 / D. Siegel-Causey

- Gibson Islands, adjacent to Attu Island, Near Islands, Bering Sea $\left(52^{\circ} 56^{\prime} 45^{\prime \prime} \mathrm{N}, 173^{\circ} 16^{\prime} 15^{\prime \prime} \mathrm{E}\right)$ 6 September 2002 / D. Causey

- Buldir Island, Bering Sea (ca. 52²1'N, 17556'E) July 1974 / C.P. Dau, G.V. Byrd, M.H. Dick August 1975 / E.P. Hoberg July 1982 / D. Forsell August 1987 / D. Nysewander August 1991 / D. Siegel-Causey

- Kiska Island, Kiska Harbor, Bering Sea (5158'01"N, 177³3'50"E) August 1992 / D. Siegel-Causey

- Nizki Island (Bozo Cove), Semichi Islands (5244'28"N, 17359'08"E) August 1991 / D. Siegel-Causey

- Seguam Island, Andreanof Islands, Bering Sea (ca. $52^{\circ} 19^{\prime} 24^{\prime \prime}$ N., 172 $27^{\prime} 58^{\prime \prime}$ W.) 31 August, 2002/ D. Causey

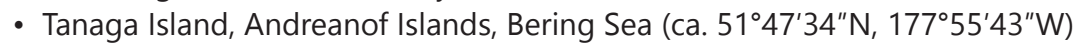
3-4 September 1997 / D. Causey

- South of Western Aleutian Islands, Pelagic Habitat, North Pacific (ca. $50-51^{\circ} \mathrm{N}, 172-174^{\circ} \mathrm{E}$ ) June-July 1981 / P.J. Gearin 28 June 1981 / P.J. Gearin (5052'4"N, 17352'1"E)

14 July 1981 / P.J. Gearin $\left(50^{\circ} 03^{\prime} \mathrm{N}, 173^{\circ} 08.6^{\prime} \mathrm{E}\right)$

June 1982 / P.J. Gearin 16, 20 July 1982 / P.J. Gearin

- South of Tanaga Island and Adak Island, Pelagic Habitat, North Pacific 8 July 1982 / P.J. Gearin

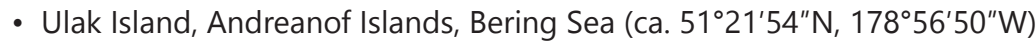
3 September 2002 / D. Causey 
Supplementary Data Table 2. (continued)

\section{Arctic Basin and Chukchi Sea}

- Little Diomede Island, Bering Strait $\left(65^{\circ} 45^{\prime} 42^{\prime \prime} \mathrm{N}, 168^{\circ} 57^{\prime} 06^{\prime \prime} \mathrm{W}\right)$

15 August 1984 / L. Lowry

- Utqiagvik Alaska (originally as Point Barrow), Chukchi Sea $\left(71^{\circ} 16^{\prime} \mathrm{N}, 156^{\circ} 50^{\prime} \mathrm{N}\right)$

May 1958 / R.L. Rausch

August 1979 / J. Homan

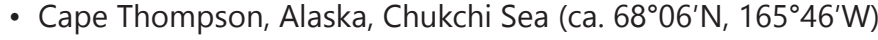

June 1959 / L.G. Swartz

June 1960 / L.G. Swartz

July 1976 / D.G. Roseneau, A.M. Springer July 1977 / D.G. Roseneau, A.M. Springer

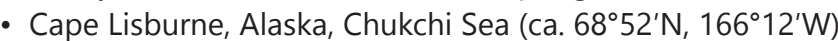
July 1977 / D.G. Roseneau, A.M. Springer

- Chaun Bay (Chaun Biological Station), East Siberian Sea, Russia (ca. 68 $44^{\prime} \mathrm{N}, 170^{\circ} 36^{\prime} \mathrm{E}$ ) July-August 1981 / V. Kontrimavichus, S. Bondarenko, A. la. Kondratiev, L. Kondratieva, G. Atrashkevich, E.P. Hoberg

\section{Bering Sea}

- St. Paul Island (Pribilof Islands), Bering Sea $\left(57^{\circ} 10^{\prime} \mathrm{N}, 170^{\circ} 20^{\prime} \mathrm{W}\right)$ July 1979 / J. Homan June 1987 / G.V. Byrd

- St. George Island (Pribilof Islands), Bering Sea $\left(56^{\circ} 36^{\prime} 00^{\prime \prime} \mathrm{N}, 169^{\circ} 32^{\prime} 00^{\prime \prime} \mathrm{W}\right)$ June 1987 / G.V. Byrd

- Pribilof Islands, Pelagic (no specific geo coordinates) August 1974 / US Fish and Wildlife Service

- Nunivak Island, Nash Harbor, Bering Sea $\left(66^{\circ} 00^{\prime} \mathrm{N}, 166^{\circ} 00^{\prime} \mathrm{W}\right)$ August 1949 / P.J. Brandly

- St. Matthew Island, Bering Sea (ca. $60^{\circ} 20^{\prime} \mathrm{N}, 171^{\circ} 00^{\prime} \mathrm{W}$ ) July-August 1982 / E.P. Hoberg, M. Dykes-Hoberg, M.K. Hoberg, D.G. Roseneau July 1983 / A.M. Springer July 1997 / D. Causey

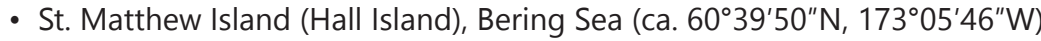
July 1997 / D. Causey

- St. Lawrence Island, Bering Sea (ca. $63^{\circ} 45^{\prime} \mathrm{N}, 171^{\circ} 40^{\prime} \mathrm{W}$ )

May 1950 / E.L. Schiller

18 August 1950 / E.L. Schiller / (6340'04"N, 170³4'08"W)

22 August 1950 / E.L Schiller/ (Gambell) (6346'48"N, 17144'25"W)

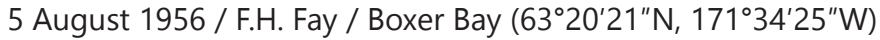

July 1959 / R.L. Rausch

August 1964 / J. Bedard / (Gambell) $\left(63^{\circ} 46^{\prime} 48^{\prime \prime} \mathrm{N}, 171^{\circ} 44^{\prime} 25^{\prime \prime} \mathrm{W}\right)$

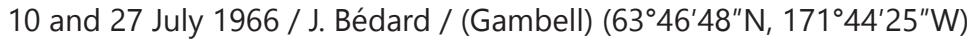

August 1966 / J. Bédard / (Gambell) (6346'48"N, 17144'25"W)

August 1968 / J. Bédard / (Gambell) $\left(63^{\circ} 46^{\prime} 48^{\prime \prime} \mathrm{N}, 171^{\circ} 44^{\prime} 25^{\prime \prime} \mathrm{W}\right)$

30-31 May, June 1981 / R. Wilson / (Savoonga) (6341'48"N, 170²7'39"W)

19 July 1981 / D.G. Roseneau, A. Springer / (Savoonga) (6341'48"N, 170²7'39"W)

June 1982 / R.L. Rausch / (Savoonga) (6341'48"N, 170²7'39"W)

June 1983 / R.L. Rausch

18 July 1987 / J. Piatt / ca. $\left(63^{\circ} 47^{\prime} \mathrm{N}, 171^{\circ} 44^{\prime} \mathrm{W}\right)$

- Sledge Island, Bering Sea $\left(64^{\circ} 29^{\prime} 45^{\prime \prime} \mathrm{N}, 166^{\circ} 12^{\prime} 08^{\prime \prime} \mathrm{W}\right)$ July 1969 / R.L. Rausch

- Wales, Alaska, Bering Sea $\left(65^{\circ} 36^{\prime} \mathrm{N}, 168^{\circ} 05^{\prime} \mathrm{W}\right)$ 22 March 1966 / R.L. Rausch

- Bering Sea, North Central (no specific coordinates) 1976, 1977 / US Fish and Wildlife Service 
Supplementary Data Table 2. (continued)

\section{Gulf of Alaska}

- Ugaiushak Island, Gulf of Alaska $\left(56^{\circ} 47^{\prime} \mathrm{N}, 156^{\circ} 41^{\prime} \mathrm{W}\right)$ May-July 1976 / E.P. Hoberg, D.H.S. Wehle

- Central Island, Gulf of Alaska (56 $\left.56^{\circ} 1^{\prime} \mathrm{N}, 156^{\circ} 53^{\prime} \mathrm{W}\right)$ June 1976 / E.P. Hoberg, D.H.S. Wehle

- Chowiet Island, Semidi Islands, Gulf of Alaska (ca. $56^{\circ} 02^{\prime} \mathrm{N}, 156^{\circ} 45^{\prime} \mathrm{W}$ ) June 1976 / G.C. Burrell

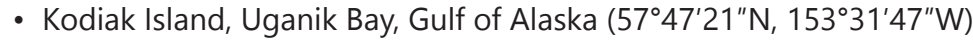
June 1953 / R.L. Rausch

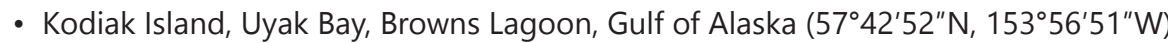
June 1953 / R.L. Rausch

- Kodiak Island, Chiniak Bay, Gulf of Alaska $\left(57^{\circ} 49^{\prime} \mathrm{N}, 152^{\circ} 30^{\prime} \mathrm{W}\right)$ June-July, 1977 / E.P. Hoberg, D. Nysewander

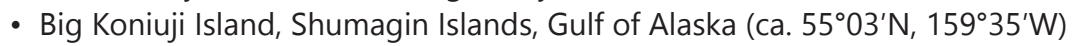
July 1976 / US Fish and Wildlife Service

- Puffin Island, Kodiak Island, Chiniak Bay, Gulf of Alaska $\left(57^{\circ} 46^{\prime} \mathrm{N}, 152^{\circ} 26^{\prime} \mathrm{W}\right)$ 10 July 1977 / E.P. Hoberg 24 July 1977 / E.P. Hoberg

- Sitkalidak Island, Kodiak Island region, Gulf of Alaska $\left(57^{\circ} 07^{\prime} \mathrm{N}, 153^{\circ} 10^{\prime} \mathrm{W}\right)$ 8 July 1977 / P. Baird, A. Moe

- Middleton Island, Gulf of Alaska $\left(59^{\circ} 29^{\prime} \mathrm{N}, 146^{\circ} 28^{\prime} \mathrm{W}\right)$ June 1956 / R.L. Rausch November 1956 / R.L. Rausch

- Shuyak Island, Big Bay, Gulf of Alaska (58 33'23"N, 152 $36^{\prime} 14^{\prime \prime} \mathrm{W}$ ) November 1954 / R.L. Rausch

- Forrester Island, Gulf of Alaska $\left(54^{\circ} 50^{\prime} \mathrm{N}, 133^{\circ} 35^{\prime} \mathrm{W}\right)$ July 1976 / A. DeGange

- Gulf of Alaska, North Central (no specific geo coordinates) 1969, 1970, 1971 / US Fish and Wildlife Service

\section{Eastern North Pacific / Washington State to California} Washington State, USA

- Grays Marine Canyon (Washington pelagic zone) $\left(46^{\circ} 55^{\prime} \mathrm{N}, 124^{\circ} 46^{\prime} \mathrm{W}\right)$ 8 September 1982 / E.P. Hoberg, D.R. Paulson, K.B. Aubry 31 August 1985 / E.P. Hoberg, S. Rohwer, K.B. Aubry, C. Spaa 21 September 1985 / E.P. Hoberg, G. Eddy, S. Rohwer 21 August 1987 / E.P. Hoberg, S. Rohwer, K.B. Aubry

- Protection Island, Washington, Strait of Juan de Fuca $\left(48^{\circ} 08^{\prime} \mathrm{N}, 122^{\circ} 55^{\prime} \mathrm{W}\right)$ July 1981 / R. Fitzner

- Destruction Island, Washington, Eastern North Pacific $\left(47^{\circ} 41^{\prime} \mathrm{N}, 122^{\circ} 55^{\prime} \mathrm{W}\right)$ July 1981 / R. Fitzner

- San Juan Island, Friday Harbor, Washington (48³2'7" N, 1231'52" W) January 1981 / E.P. Hoberg

- San Juan Island, Wescott Bay, Washington (ca. 48 30'N, $123^{\circ} 05^{\prime} \mathrm{W}$ ) February 1982 / W.G. English

- Pt. Roberts (Southern Strait of Georgia $\left[49^{\circ} 00^{\prime} \mathrm{N}, 123^{\circ} 05^{\prime} \mathrm{W}\right]$ ) January 1964 / R.A. Ryder

- Sequim Bay, Olympic Peninsula, Washington, Strait of Juan de Fuca (ca. $48^{\circ} 05^{\prime} \mathrm{N}, 123^{\circ} 00^{\prime} \mathrm{W}$ ) November 1981 / E.P. Hoberg, R. Fitzner 
Supplementary Data Table 2. (continued)

\section{California, USA}

- Humboldt Bay, California, Eastern North Pacific (ca. $40^{\circ} 49^{\prime} \mathrm{N}, 124^{\circ} 10^{\prime} \mathrm{W}$ ) June 1977 and 1979 / M. Phillips

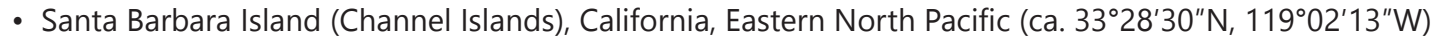
10 June 1987 / C. Drost 12 May 1988 / C. Drost

\section{Sea of Okhotsk, Russia}

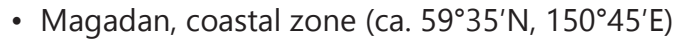
August 1981 / A. la. Kondratiev

- Khmotiyevskogo Peninsula (near Talan Island), northern Sea of Okhotsk (ca. $59^{\circ} 18^{\prime} \mathrm{N}, 148^{\circ} 56^{\prime} \mathrm{E}$ ) 30 July 1988 / L. Kondratieva

- Talan Island, northern Sea of Okhotsk (ca. 59 $19^{\prime} \mathrm{N}, 149^{\circ} 06^{\prime} \mathrm{E}$ ) July-September 1988 / E.P. Hoberg, A. la. Kondratiev, L. Kondratieva, S. Bondarenko, A. Kitaysky 
Supplementary Data Table 3.

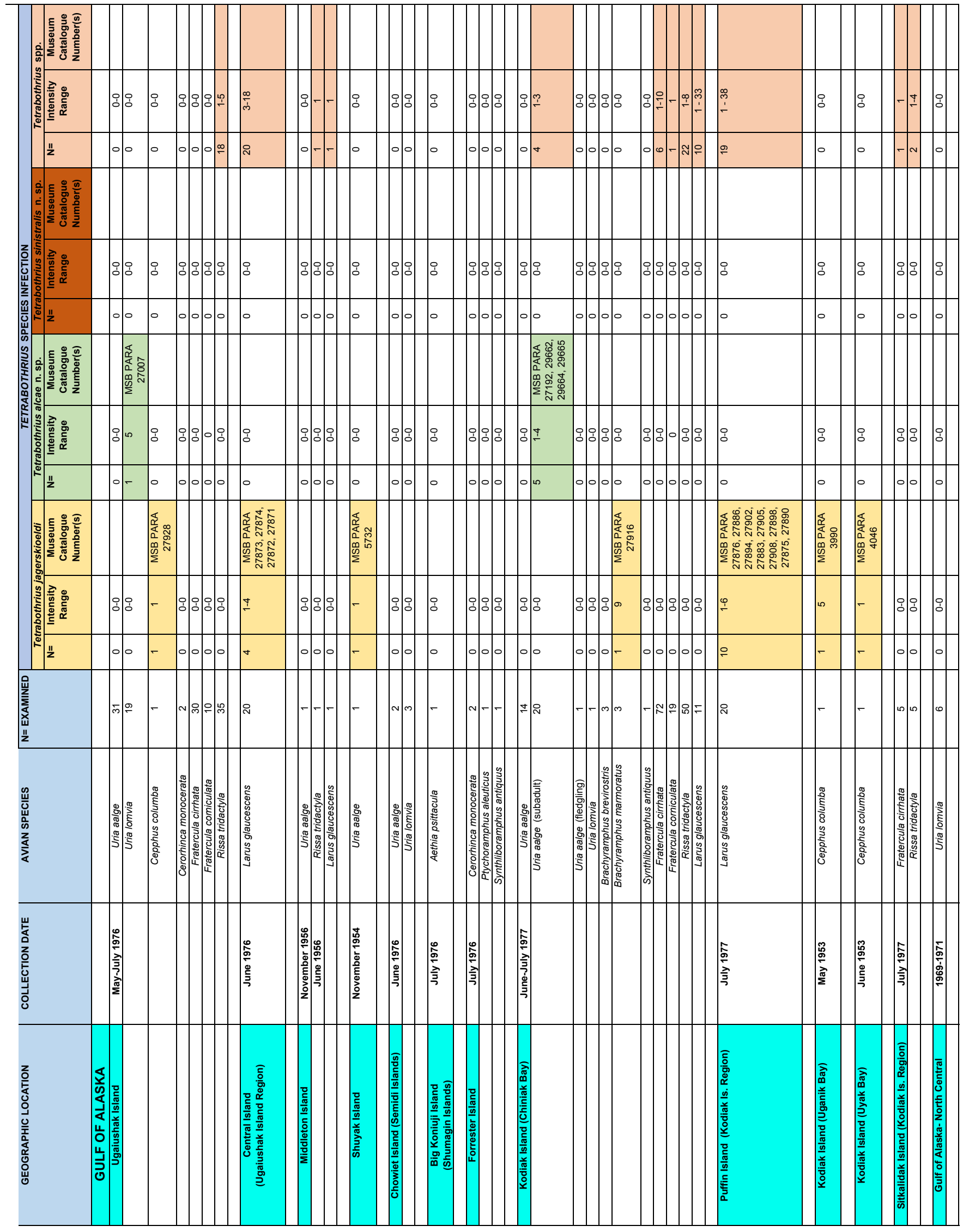


Supplementary Data Table 3. (continued)

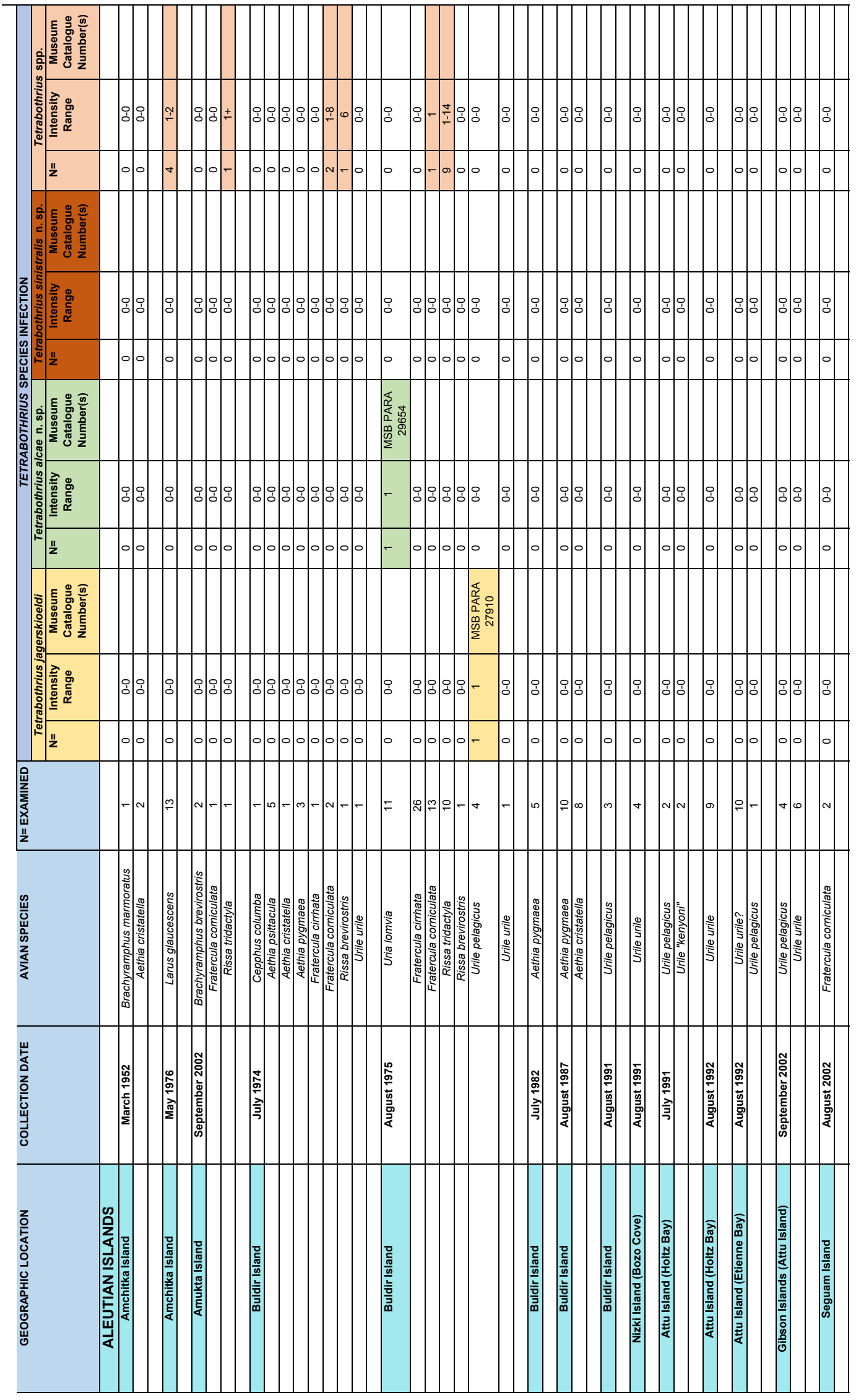


Supplementary Data Table 3. (continued)

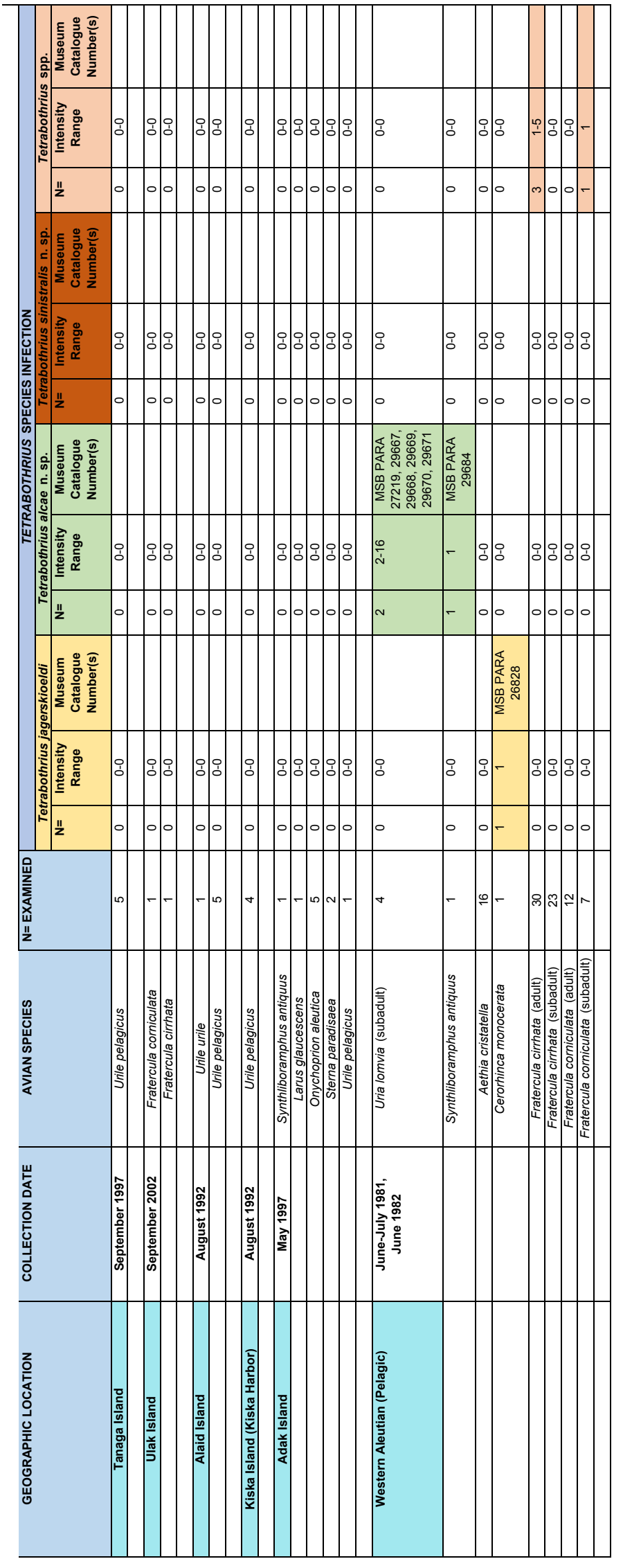


Supplementary Data Table 3. (continued)

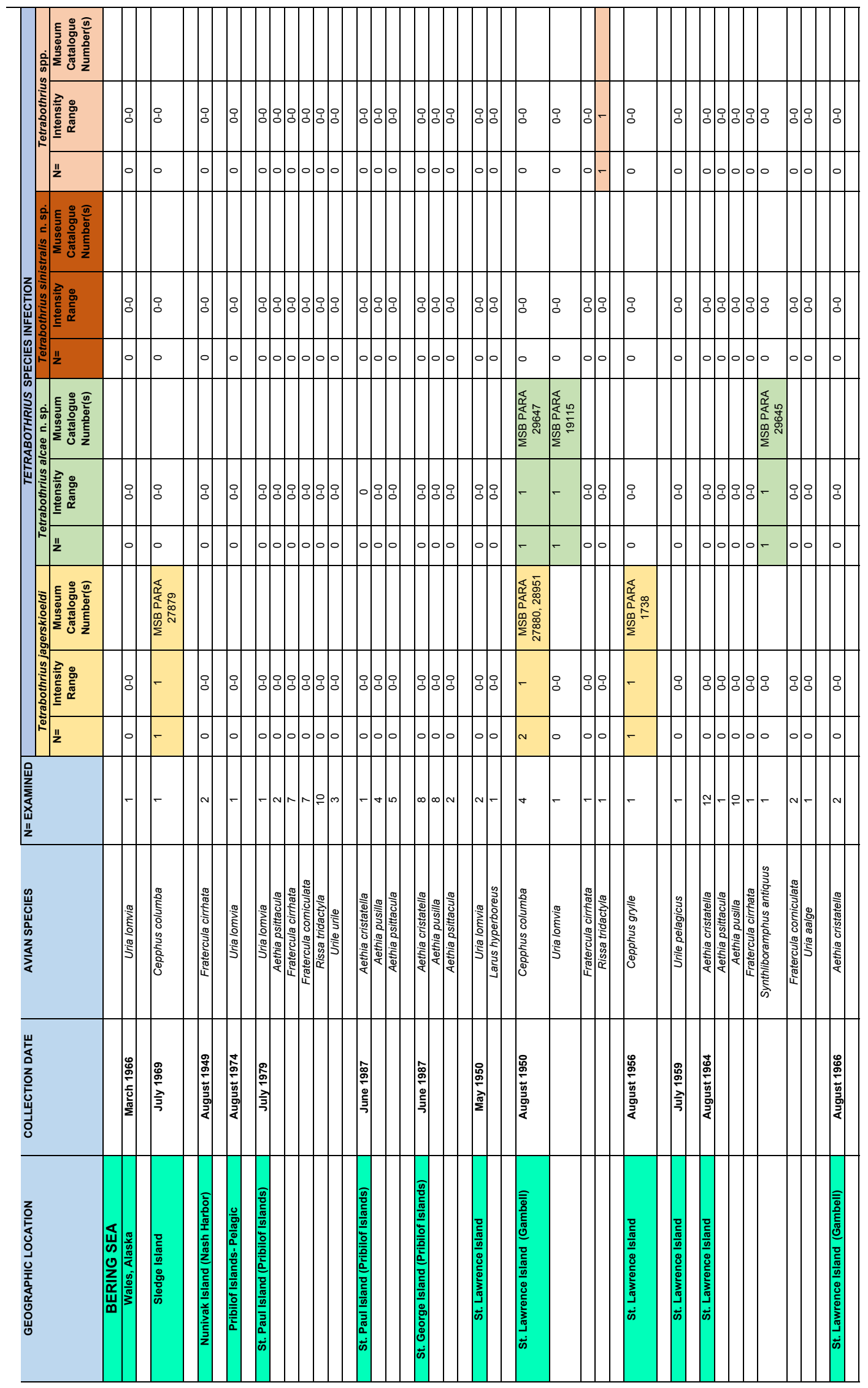


Supplementary Data Table 3. (continued)

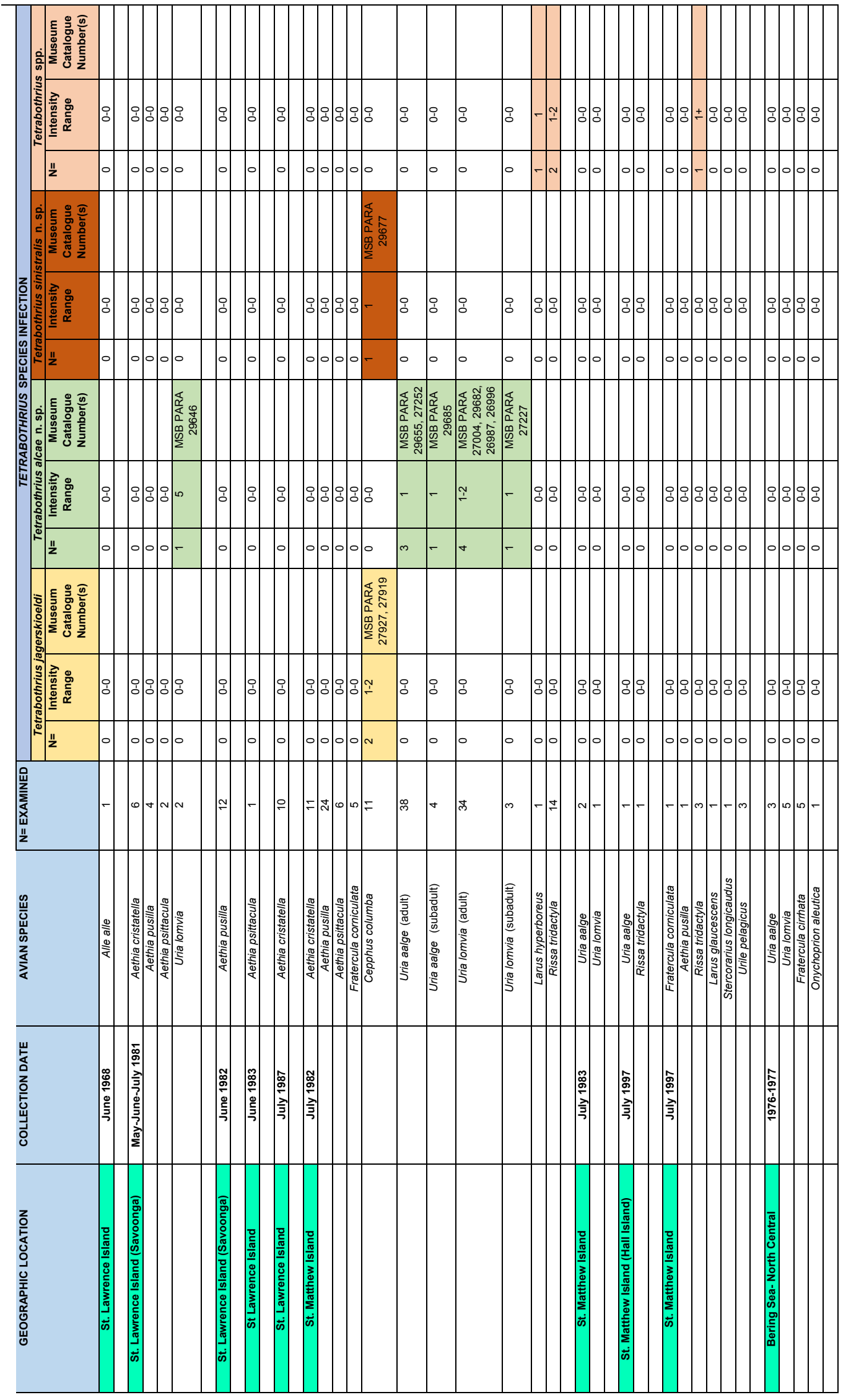


Supplementary Data Table 3. (continued)

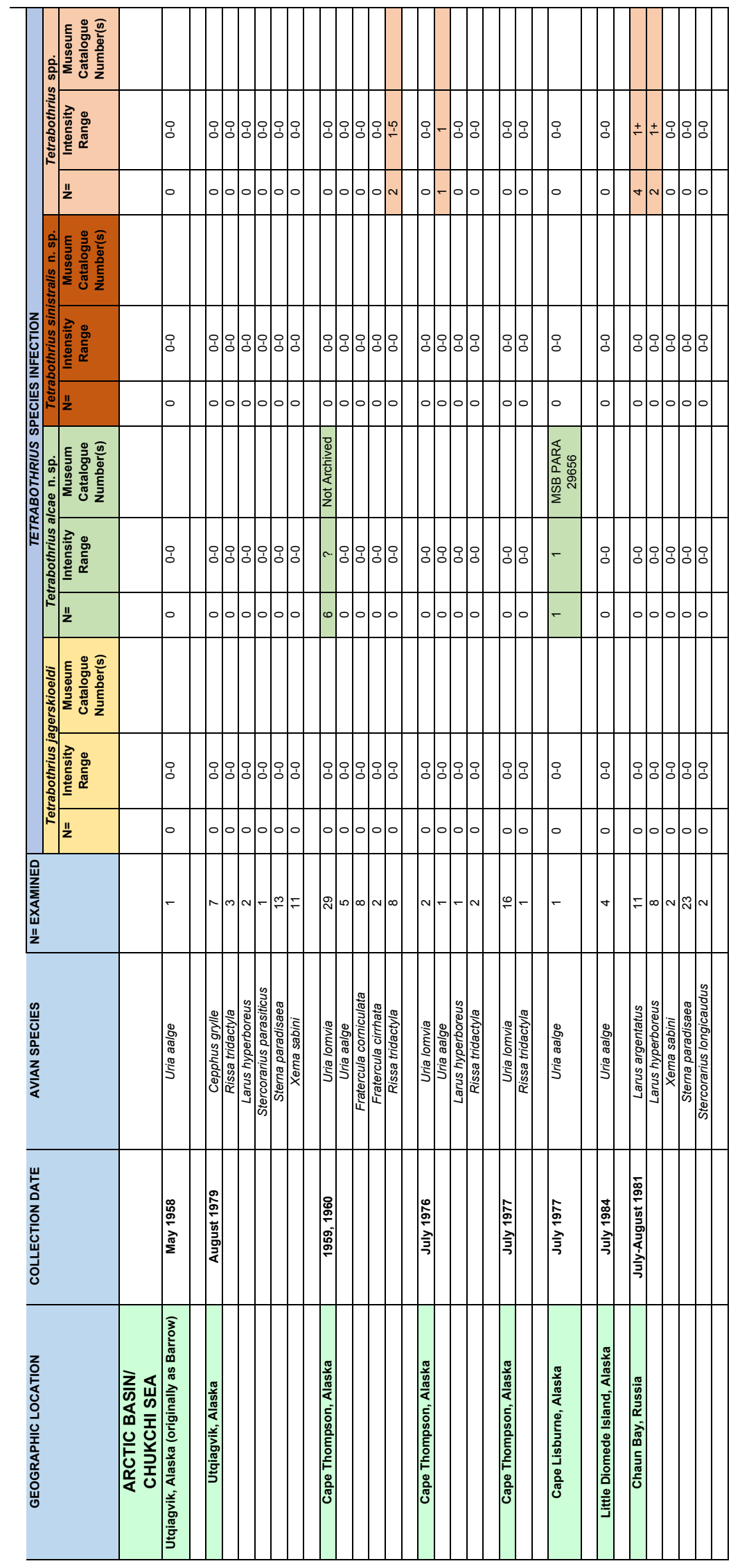


Supplementary Data Table 3. (continued)

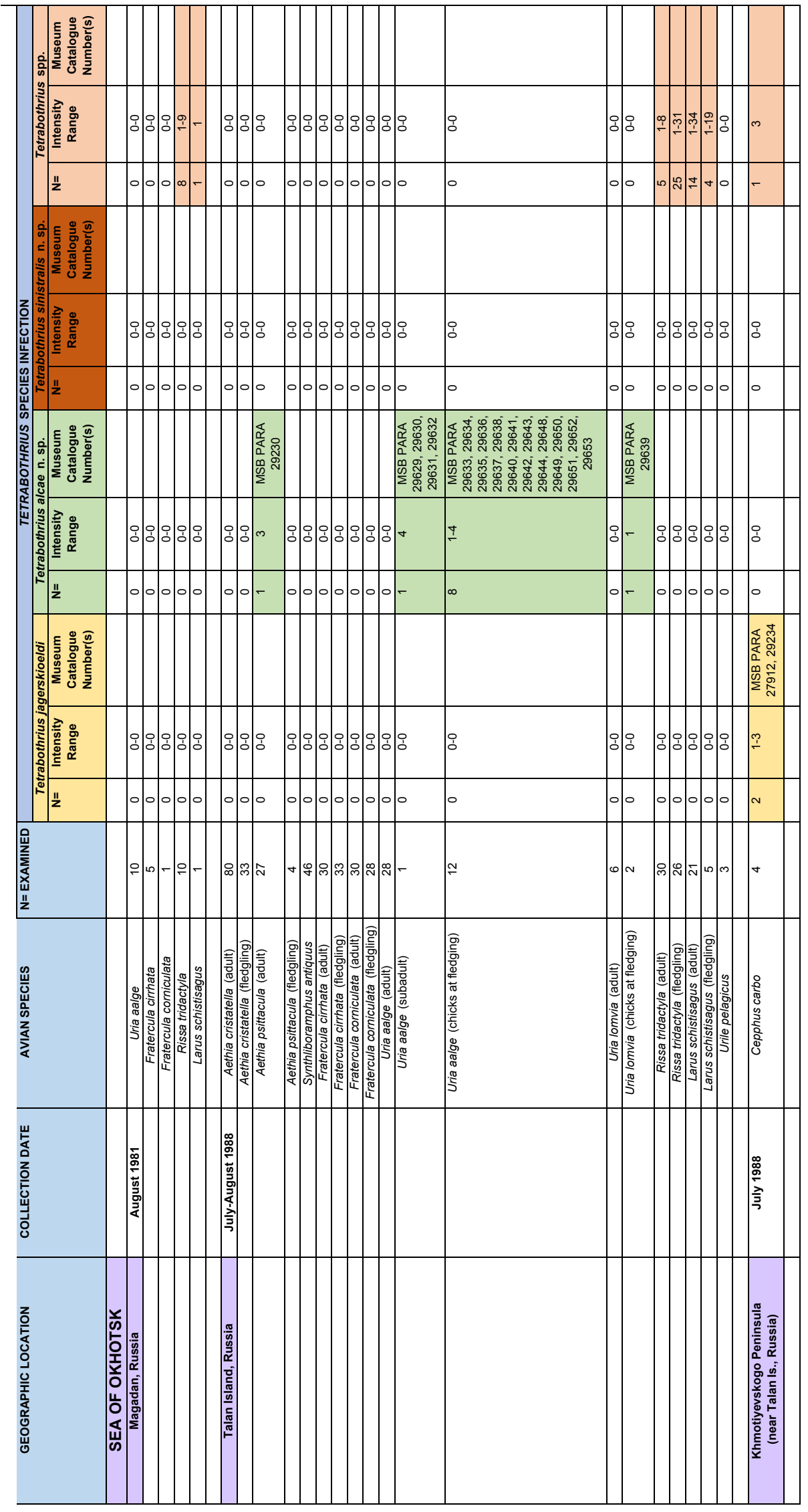


Supplementary Data Table 3. (continued)

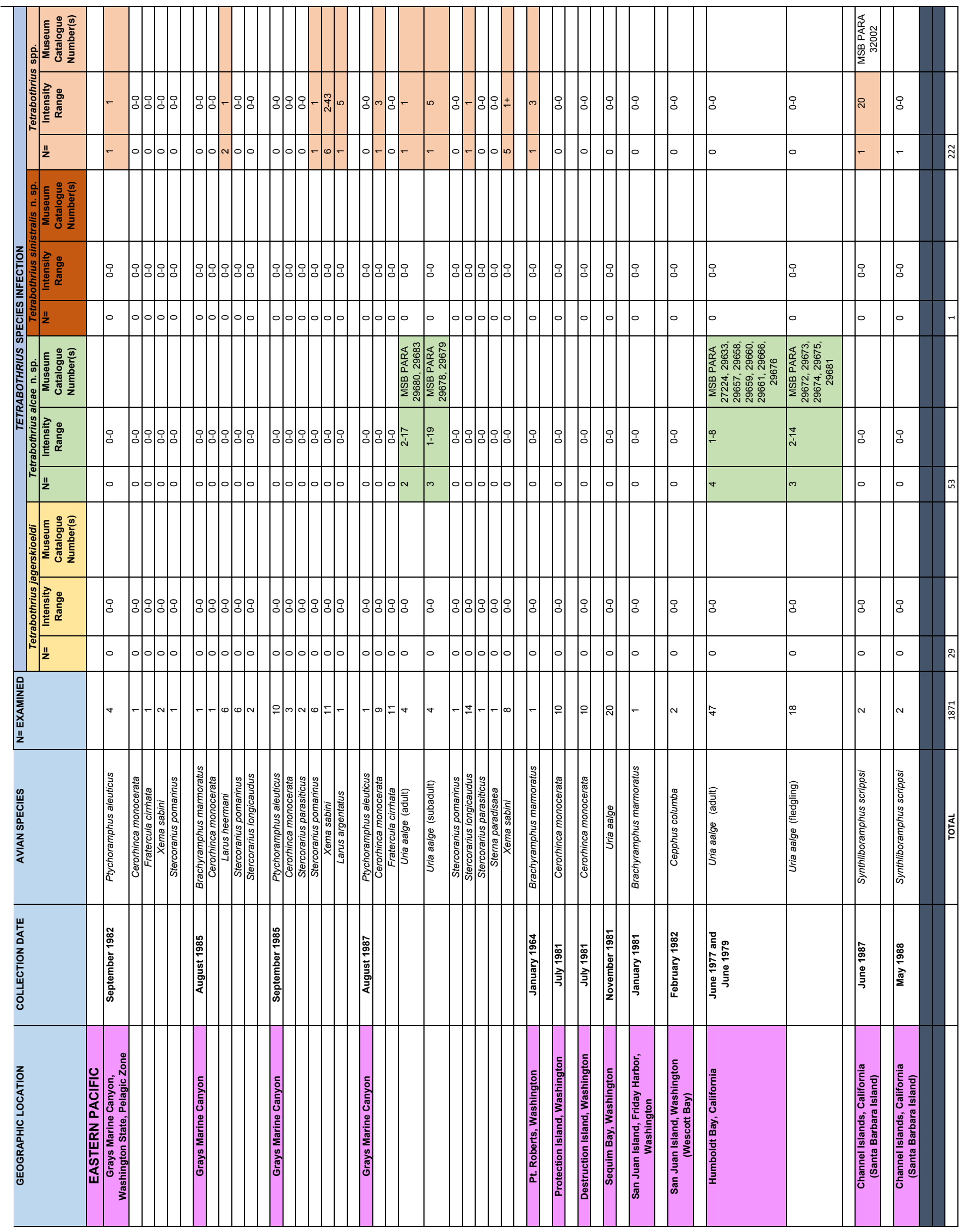


Supplementary Data Table 4. Tetrabothrius alcae n. sp. and Tetrabothrius sinistralis n. sp. Type Series and Voucher Specimens Catalogued in the Museum of Southwestern Biology

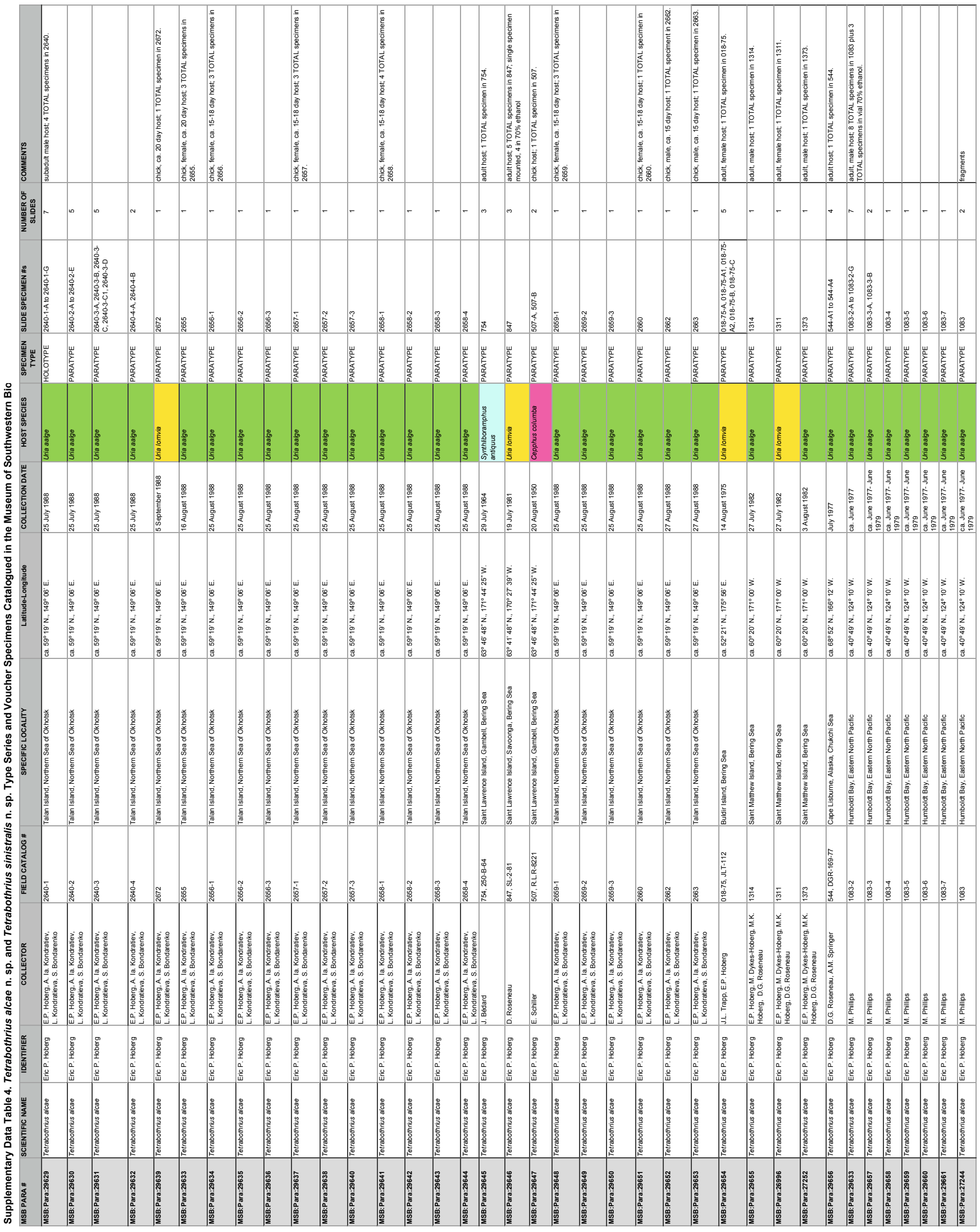


Supplementary Data Table 4. (continued)

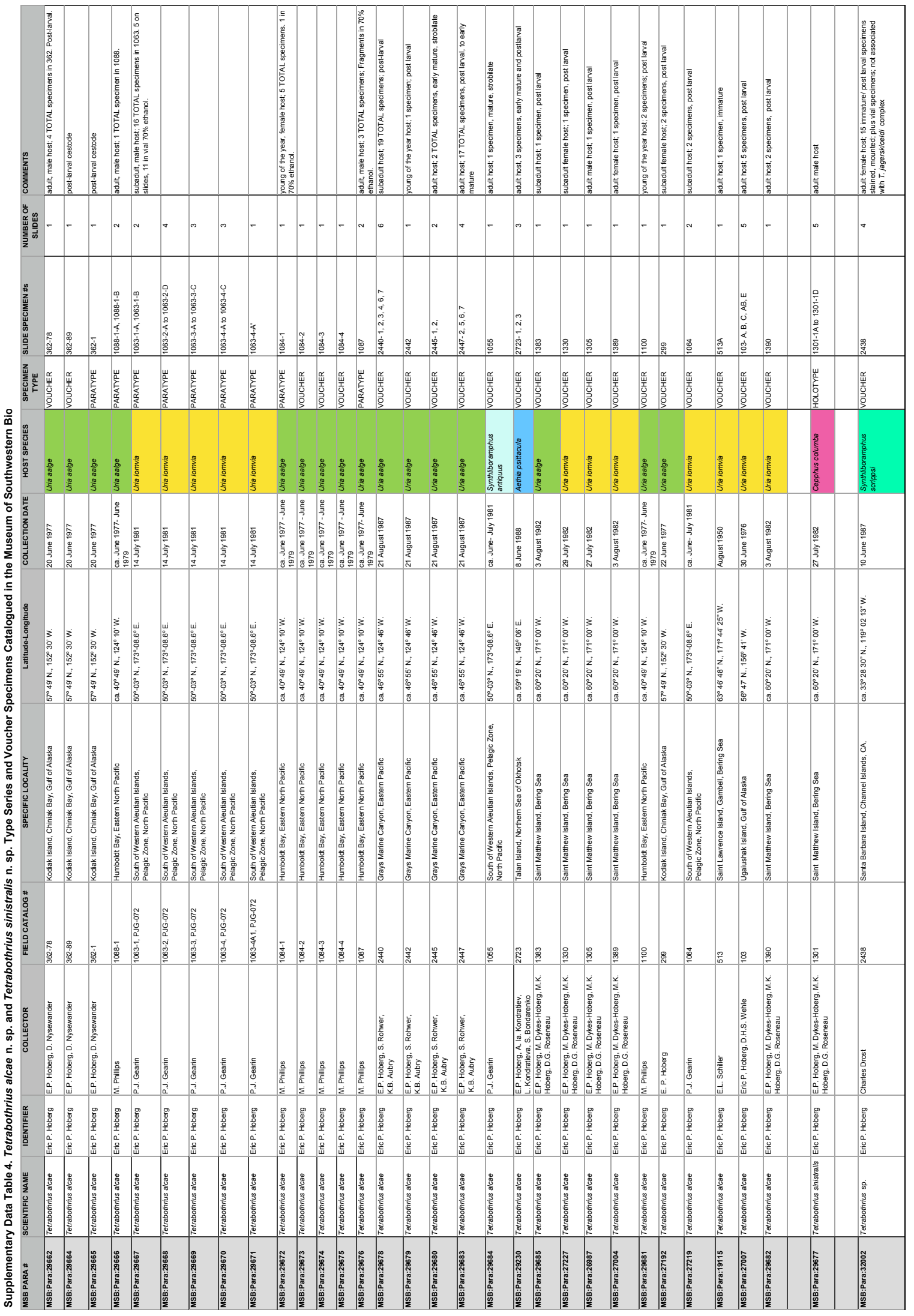




\section{Tetrabothrius jagerskioeldi Nybelin, 1916: Images for Comparative Diagnostics and Identification of Adult Strobilate Tapeworms}

Primary data for hosts, localities of collection, and methods of preparation are summarized in Hoberg and Soudachanh (2020). Scale bars in micrometers.

Figures 1-4. Scolex. Fig. 1. Adult scolex in Uria aalge (Pontoppidan, 1763) (MSB 5732). Dorso-ventral view, showing flattened bothridia and prominent auricular appendages (Figs. 1-3 same scale). Fig. 2. Adult scolex in Cepphus columba Pallas, 1811 (MSB 27927). Lateral view; note prominent, muscular auricle. Fig. 3. Adult scolex in C. columba (MSB 27880). Dorso-ventral view; note inflated apical region, indicative of recent infection and development of the scolex. Fig. 4. Scolex in postlarval specimen with early strobilization, attaining immature development in Cepphus carbo Pallas, 1811 (MSB 29234). Lateral view of scolex, showing pedicle structure following loss of apical sucker and development of bothridia and auricles.

Figures 5-7. Genital atrium and cirrus sac in development. Fig. 5. Proglottids in ventral view showing mature development of cirrus sac (cs), genital atrium (ga), dorsal bar (db), and position of the ventral osmoregulatory canal (vosm) in Cepphus columba (MSB 27880). Fig. 6. Proglottids in ventral view in mature specimen showing genital pore (ge), cirrus sac (cs), genital atrium (ga), vas deferens (vd), and uterine stem (ut) in Cerorhinca monocerata (Pallas, 1811) (MSB 26828). Fig. 7. Proglottids in dorsal view in pregravid strobila showing structure of the genital atrium, dorsal bar ( $d b)$, cirrus sac (cs), and transverse uterus under expansion (ut) in C. columba (MSB 27927).

Figures 8-10. Genital atrium in transverse sections (hand-cut). Fig. 8. Genital atrium in late maturity, from posterior, dorsal to top, in Brachyramphus marmoratus (Gmelin, 1789) (MSB 27916). Shown are relative positions of the cirrus sac (cs), transverse uterine stem (ut) extending between the dorsal (dosm) and ventral (vosm) osmoregulatory canals, vagina (va), muscular genital atrium (ga), genital pore (ge), and inner (im) and outer (om) longitudinal muscle bundles. Fig. 9. Genital atrium in late maturity (MSB 27916), showing details of the terminal male and female genital ducts (arrows), position and structure of the muscular dorsal bar (db), cirrus sac (cs), and vagina (va). Fig. 10. Genital atrium in pregravid proglottid, from anterior, dorsal to top, in Uria aalge (MSB 5732), showing genital ducts, dorsal bar (db), genital pore (ge), cirrus sac (cs), vagina (va), and the inner (im) and outer (om) muscle bundles.

Figures 11-12. Genital organ complex in male and female, from whole mounts. Fig. 11. Proglottid in maturity to late maturity showing dorsal view with distribution and structure of organ systems. Note the lobate, biwinged ovary (ov), compact vitelline gland (vt), spindle-shaped vaginal seminal receptacle (vsr with arrow), cirrus sac (cs), and genital atrium (ga), in Cepphus columba (27879). Fig. 12. Proglottid in maturity to late maturity in dorsal view. Note ovarian wing (ov), vaginal seminal receptacle crossing osmoregulatory canals (between) (osm), in C. columba (27879).

Figures 13-15. Gravid proglottids and uterus. Fig. 13. Developing lobate uterus, in Cepphus columba (MSB 27927), ventral view. Transverse uterus (ut) extends toward poral margin; note relationship to cirrus sac (cs) and genital pore (ge). Fig. 14. Patent uterine pores, mid-dorsal near anterior margin, in successive gravid segments near termination of strobila, dorsal view (arrows), in C. columba (MSB 27880). Fig. 15. Gravid uterus in successive proglottids near termination of strobila, dorsal view, in C. columba (MSB 27879-A4). Note uterus extends beyond osmoregulatory systems to fill proglottid; note position of genital pore (ge). Some segments are devoid of eggs, which have been released through the dorsal uterine pores. 

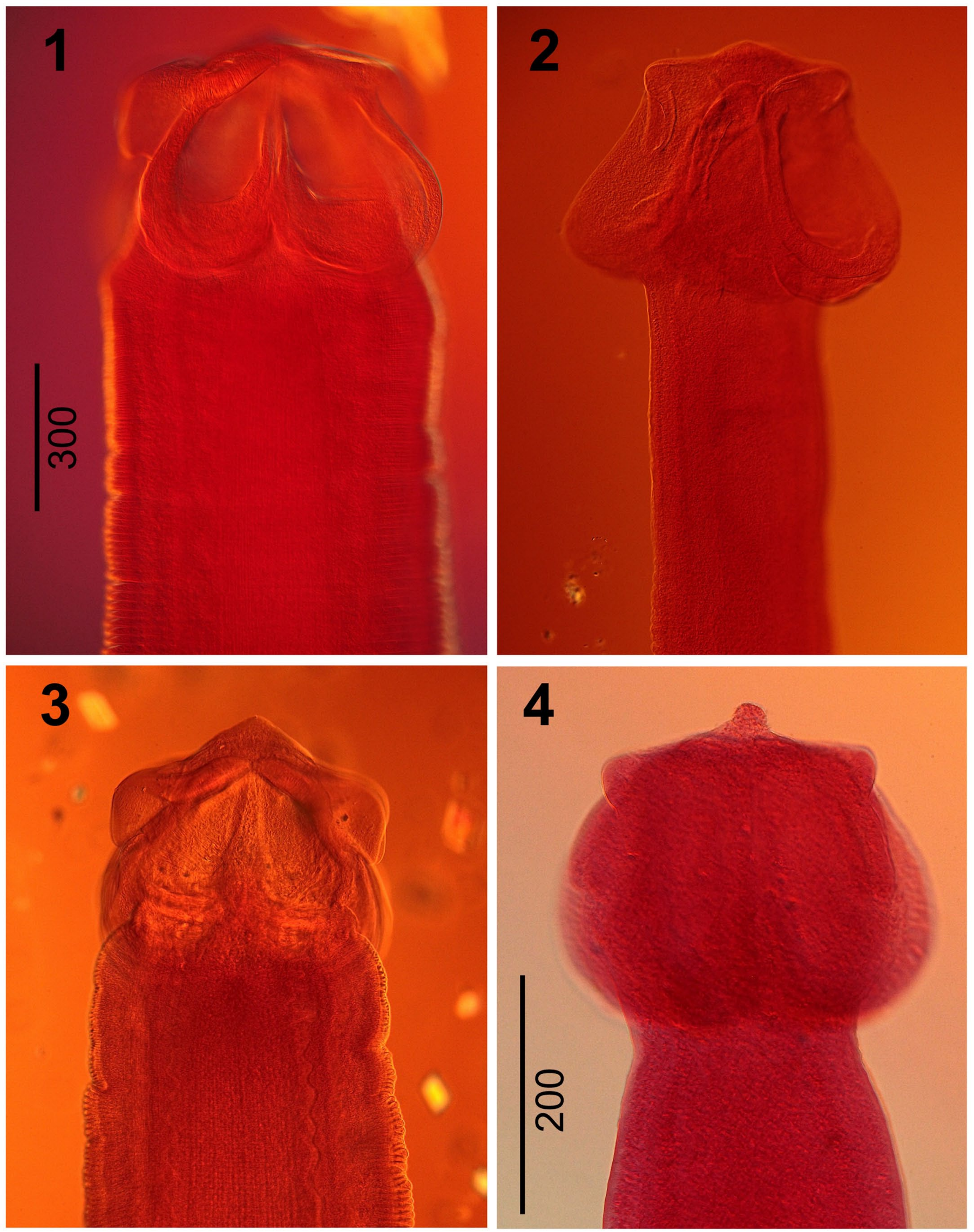

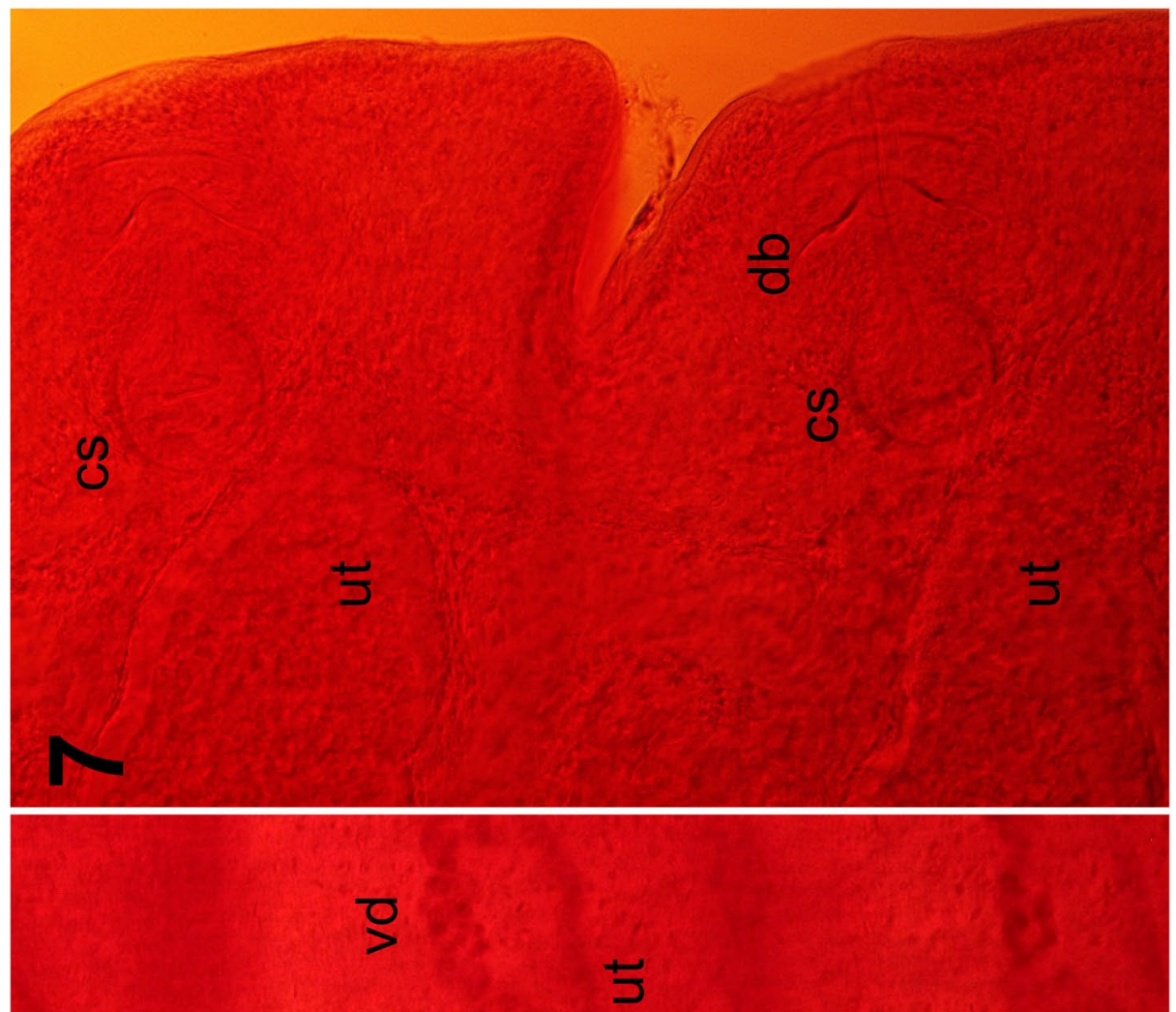

$\circlearrowleft$
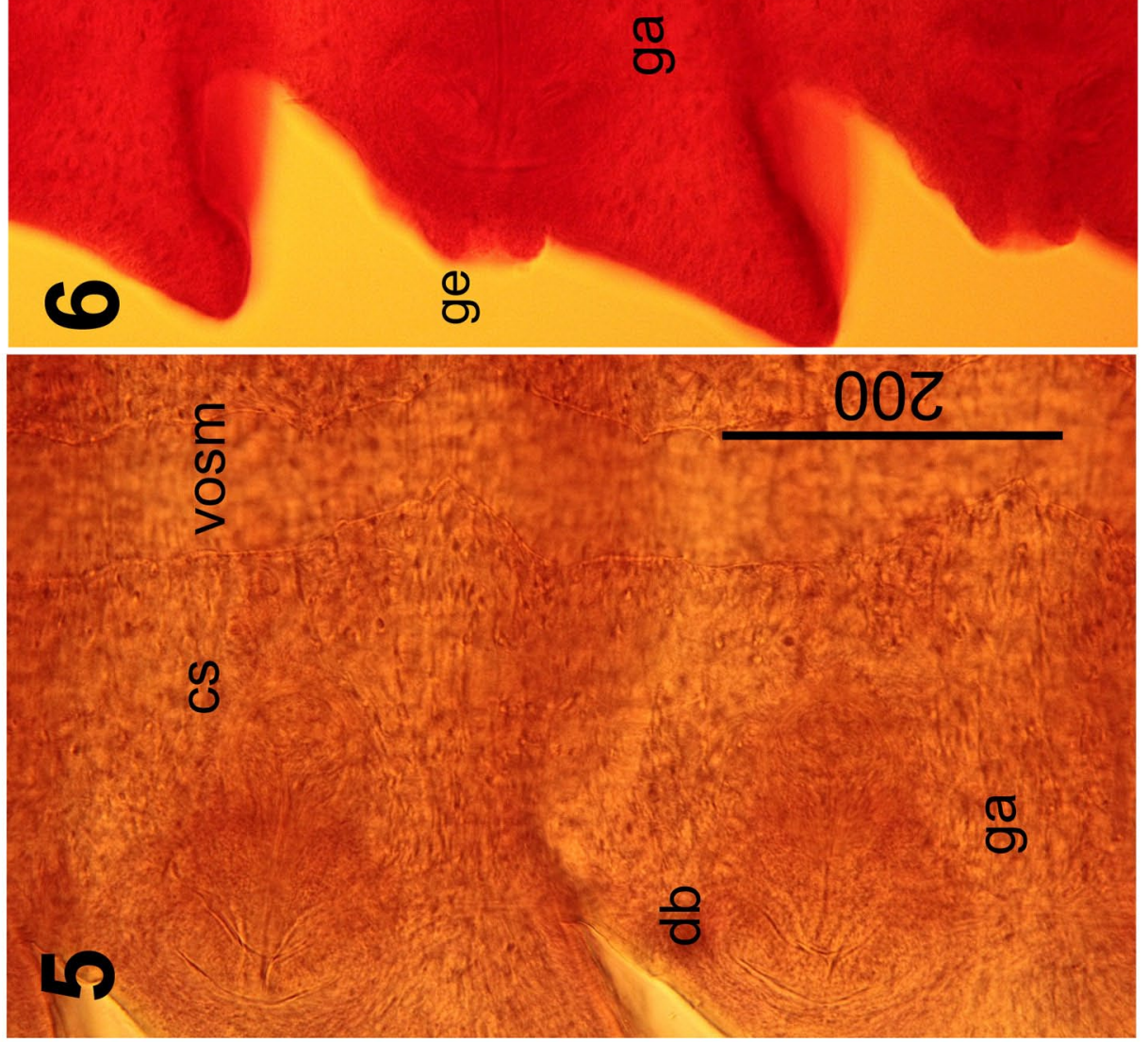


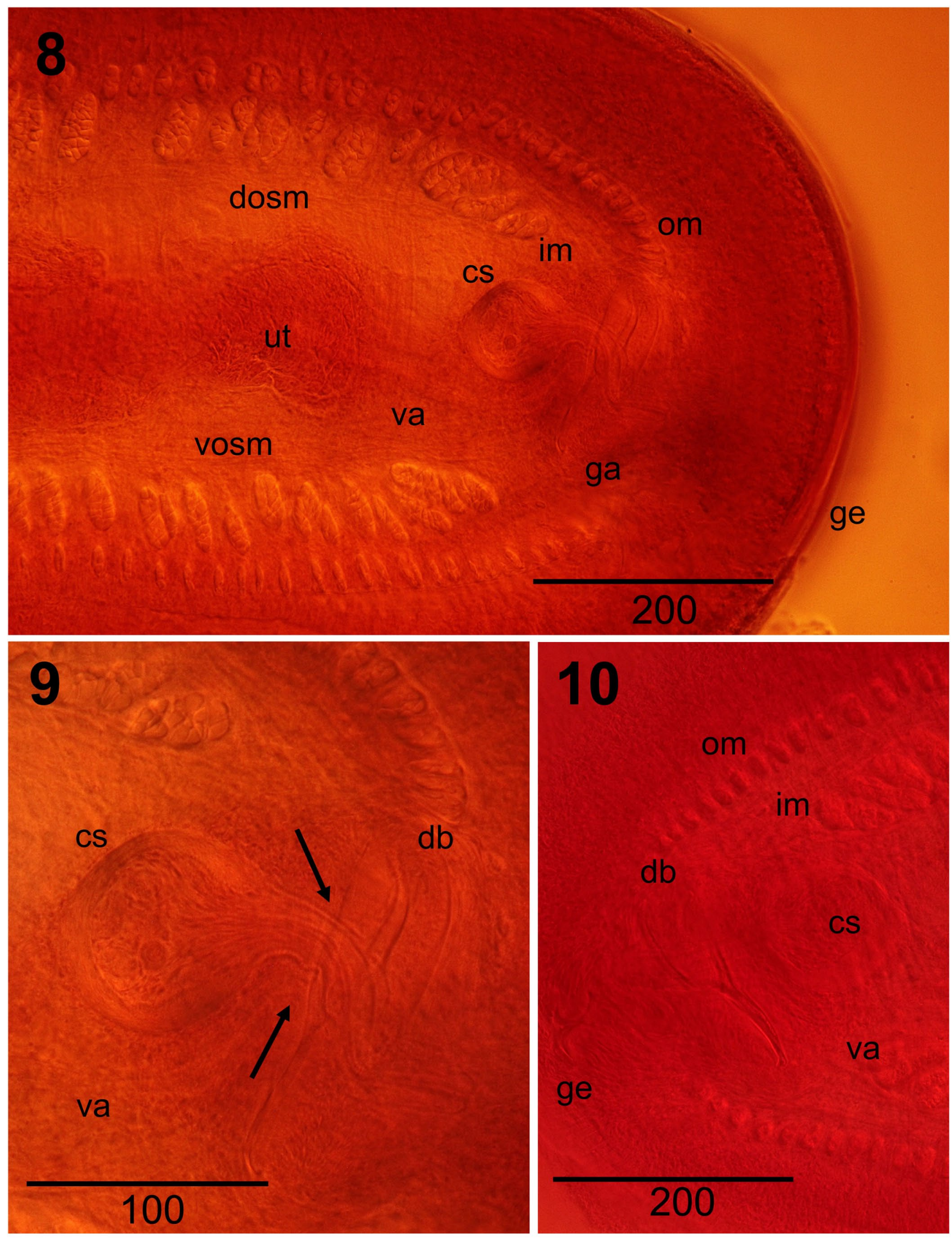



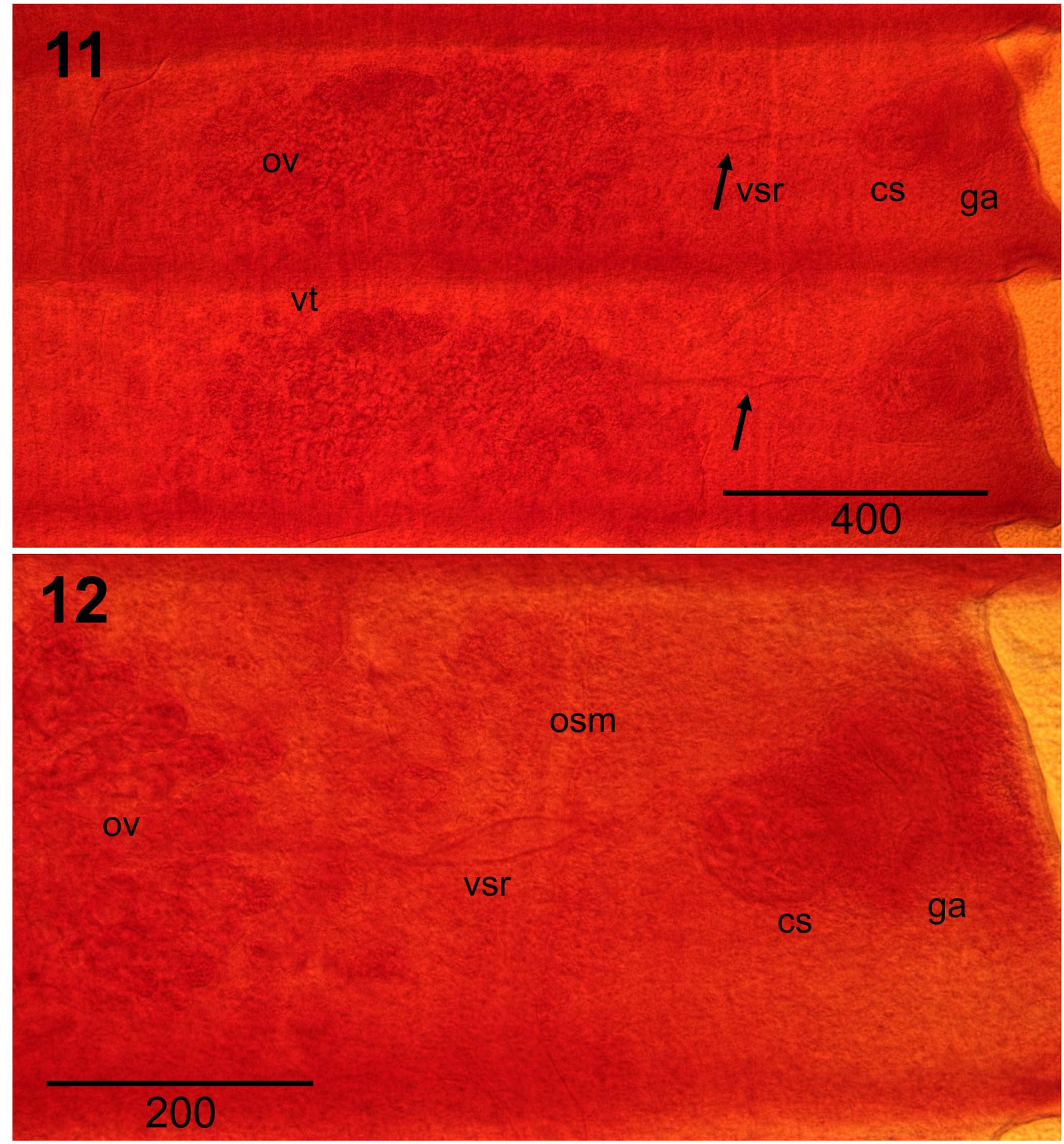


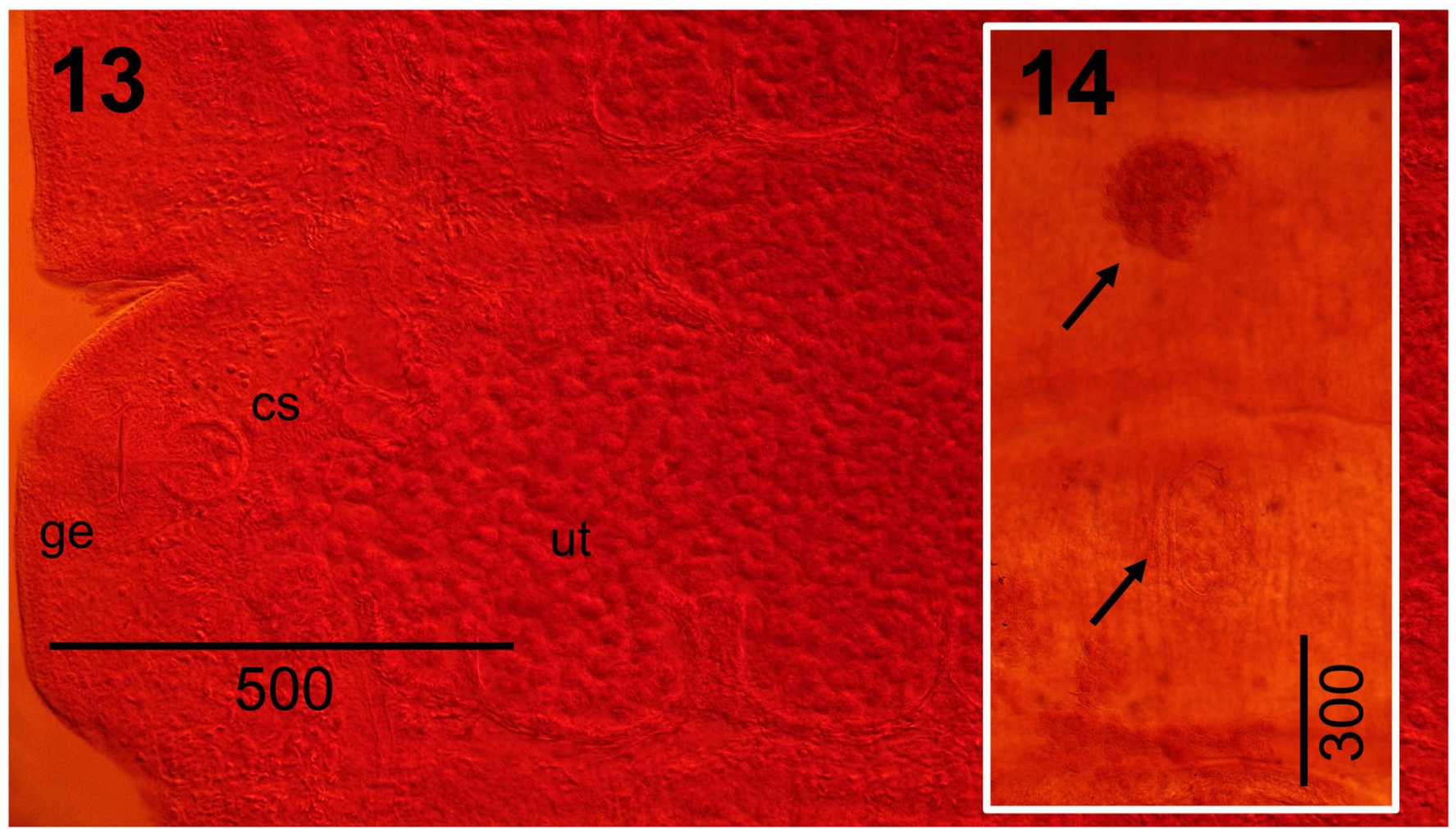

15 